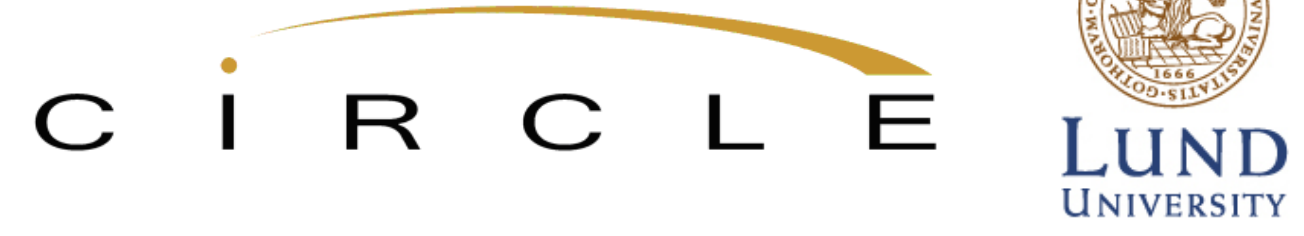

Paper no. 2011/08

\title{
Entrepreneurship: Exploring the Knowledge Base
}

\author{
Hans Landström (Hans.Landstrom@fek.lu.se) \\ CIRCLE and Dept of Small Business Management and \\ Entrepreneurship, Lund University, Sweden
}

Gouya Harirchi (gh.ino@cbs.dk) Department of Innovation and Organizational Economics, Copenhagen Business School, Denmark

Fredrik Åström (Fredrik.Astrom@lub.lu.se) Lund University Libraries, Lund University, Sweden

This is a pre-print version of a paper that has been submitted for publication to a journal

This version: September 2011

Centre for Innovation, Research and Competence in the Learning Economy (CIRCLE)

Lund University

P.O. Box 117, Sölvegatan 16, S-221 00 Lund, SWEDEN

http://www.circle.lu.se/publications

ISSN 1654-3149 
WP 2011/08

Entrepreneurship: Exploring the Knowledge Base

Hans Landström, Gouya Harirchi and Fredrik Åström

\begin{abstract}
Entrepreneurship research has a long tradition and since the 1980s the field has grown significantly. In this study we identify the 'knowledge producers' who have shaped the field over time and their core entrepreneurship research works. A unique database consisting of all references in twelve entrepreneurship 'handbooks' (or state-of-the-art books) has been developed. The chapters in these handbooks were written by experts within the field, and it can be assumed that the most frequently cited references represent 'core knowledge' with relevance to entrepreneurship research.
\end{abstract}

From our analysis, it appears that entrepreneurship is a rather changeable field of research, closely linked to disciplines such as 'management studies' and 'economics'. Over time, the field has become more formalized with its own core knowledge, research specialities and an increasing number of 'insider works'. However, it is still based on some fairly old theoretical frameworks imported from mainstream disciplines, although during the last decade we have seen the emergence of a number of new field-specific concepts and theories. We argue that to successfully develop entrepreneurship research in the future, we need to relate new research opportunities to earlier knowledge within the field, which calls for a stronger 'knowledge-based' focus. We would also like to see greater integration between the fields of entrepreneurship and innovation studies in the future.

\title{
Keywords:
}

entrepreneurship, research field, handbooks, bibliometric analysis

Disclaimer: All the opinions expressed in this paper are the responsibility of the individual author or authors and do not necessarily represent the views of other CIRCLE researchers. 


\title{
ENTREPRENEURSHIP: EXPLORING THE KNOWLEDGE BASE
}

\author{
Hans Landström \\ CIRCLE, Lund University, Sweden \\ and \\ Department of Small Business Management and Entrepreneurship, \\ Vienna University of Economics and Business, Austria \\ PO Box 7080, S-220 07 Lund, Sweden \\ Hans.Landstrom@fek.lu.se \\ Gouya Harirchi \\ Department of Innovation and Organizational Economics, \\ Copenhagen Business School, Denmark \\ gh.ino@cbs.dk \\ Fredrik Åström \\ Lund University Libraries, Lund University, Sweden \\ Fredrik.Astrom@,lub.lu.se
}

\begin{abstract}
Entrepreneurship research has a long tradition and since the 1980s the field has grown significantly. In this study we identify the 'knowledge producers' who have shaped the field over time and their core entrepreneurship research works. A unique database consisting of all references in twelve entrepreneurship 'handbooks' (or stateof-the-art books) has been developed. The chapters in these handbooks were written by experts within the field, and it can be assumed that the most frequently cited references represent 'core knowledge' with relevance to entrepreneurship research.

From our analysis, it appears that entrepreneurship is a rather changeable field of research, closely linked to disciplines such as 'management studies' and 'economics'. Over time, the field has become more formalized with its own core knowledge, research specialities and an increasing number of 'insider works'. However, it is still based on some fairly old theoretical frameworks imported from mainstream disciplines, although during the last decade we have seen the emergence of a number of new field-specific concepts and theories. We argue that to successfully develop entrepreneurship research in the future, we need to relate new research opportunities to earlier knowledge within the field, which calls for a stronger 'knowledge-based' focus. We would also like to see greater integration between the fields of entrepreneurship and innovation studies in the future.
\end{abstract}

Key words: entrepreneurship, research field, handbooks, bibliometric analysis 


\section{INTRODUCTION}

Entrepreneurship is an emerging research field that has received much attention over the last few decades. However, there is a lack of consensus on precisely what constitutes entrepreneurship and in many cases it has either been related to the 'entrepreneurial individual' or framed as the creation and running of one's own firm (Davidsson, 2005). In an attempt to refine these simple definitions of entrepreneurship, Shane and Venkataraman (2000, p. 218) offered a more comprehensive one: 'The field of entrepreneurship [is] the scholarly examination of how, by whom, and with what effects opportunities to create future goods and services are discovered, evaluated and exploited'. Thus, they argue that entrepreneurship involves sources of as well as the processes of discovery, evaluation and exploitation of opportunities, but also the set of individuals who discover, evaluate and exploit these opportunities (Hitt, Ireland, Sirmon and Trahms, 2011).

The evolution of research fields - their rise, institutionalization and possible demise - forms a central part of social science studies. An example is Fleck (1979), who talked about 'styles of thought' in the institutionalization of research fields, and this is also a theme discussed in Kuhn's famous paradigm theory (1970). Both Fleck and Kuhn stressed the collective nature of knowledge production and adhered to a structural understanding of scientific development, but paid very little attention to the contributions of individual scholars. In the present article we will contribute to this discussion by arguing that the emergence of a research field can be regarded as an entrepreneurial achievement in itself. Some individual scholars identify changes in society, recognise opportunities in the form of interesting research questions and exploit certain ideas by making the new phenomena visible. They thereby attract other researchers and gradually establish the field by creating an institutional framework including conferences, scientific journals, chairs, etc. Thus, the emergence of entrepreneurship research is characterized by many entrepreneurial initiatives pursued by scholars who created new research opportunities and launched novel concepts and theories that help us understand entrepreneurship as a phenomenon. It also involves scholars who have been instrumental in building an infrastructure within the field (e.g. drove the creation of new journals, professional organizations and conferences) as well as contributing to entrepreneurial achievements at a 'micro-level' in which individual entrepreneurship scholars at universities around the world fight against a rather un-appreciative and discipline-oriented academic 
organization in order to establish entrepreneurship as a field of research and education within the university.

In line with this reasoning, the evolution of entrepreneurship as a research field will be elaborated on. We will use bibliometric analysis and focus on those researchers who have contributed to the wide-ranging knowledge of entrepreneurship as a phenomenon and to a lesser extent pay attention on scholars who have been instrumental in building institutional frameworks within the field (e.g. conferences, scientific journals and education programmes). Thus, we will focus on the knowledge producers, i.e. the core entrepreneurship research scholars who have been instrumental in the cognitive evolution of the field and their works that shaped it over time. In the study we will answer research questions related to the knowledge production of core works in entrepreneurship research, such as: 'Who are the leading knowledge producers within the field?' and 'What core works can be identified in entrepreneurship research?' In addition, we will also focus on the knowledge users of entrepreneurship research, i.e. those who have used the core works of the knowledge producers in order to contribute to and further develop our knowledge of entrepreneurship as well as other fields of research. Accordingly, we will pose the question: 'Who uses the entrepreneurship core works?' and relate our analysis to the geographic location of these knowledge users, where they publish their results and the subject areas in which they publish.

The field of entrepreneurship research is now approximately 30-40 years old and has become a significant field of intellectual activity involving thousands of scholars. Therefore, it is timely to look back and more systematically analyse what has been achieved and, not least, attempt to identify the main intellectual contributions made by researchers within the field. We believe that it is beneficial to periodically reflect on the knowledge acquired in order to establish a basis for the future development of entrepreneurship as a research field. In the study we have done this by using a unique database consisting of all references included in twelve 'handbooks' or state-of-the-art books published within the field of entrepreneurship since the 1980s, the chapters of which were written by experts and prominent scholars. It can be assumed that the most frequently cited references in these surveys represent the 'core literature' of entrepreneurship research. Thus, the method used involves a focus on the leading scholars who produced the core works within the field. 
The rest of the paper is structured into five main sections. Firstly, we will present a broad overview of the history of entrepreneurship research, followed by a discussion concerning the methodological aspects of this study. The third section focuses on the knowledge producers and identifies the top-ranked scholars within the field as well as their most influential works. In the fourth section we change perspective and analyse the knowledge users within the field, including a discussion about their geographic location and the thematic focus of their research. The final section offers some concluding reflections.

\section{ENTREPRENEURSHIP AS AN EVOLVING RESEARCH FIELD}

Historical reviews of entrepreneurship as an evolving field of research, based on the reading and understanding of individual authors, have been carried out by several scholars (e.g. Hébert and Link, 1982; 2009; Swedberg, 2000; Parker, 2005; Landström, 2005; Landström and Benner, 2010). In this section we will elaborate on the early thinking on entrepreneurship as a specialised topic in several mainstream disciplines as well as on the evolving field of entrepreneurship in its own right.

\section{Entrepreneurship as a topic in mainstream disciplines}

The function of entrepreneurship is probably as old as exchange and trade between individuals, but it was not until the emergence of economic markets during the Middle Ages that the concept gained importance and authors started to take an interest in the phenomenon. The first author to endow entrepreneurship with a more precise economic meaning was Richard Cantillon in his Essai sur la Nature du Commerce en Général (1755/1999), in which he outlined the principles of the early market economy based on individual property rights and economic interdependency. In the mid-eighteenth century, classic economic theory was developed based on Adam Smith's seminal work Inquiry into the Nature and Causes of the Wealth of Nations, first published in 1776. To a large extent this work laid the foundation for the analysis of the way the market economy functions, but it also influenced the view of the entrepreneur in the economy, who more or less disappeared from economic theory for a considerable time.

Although interest in entrepreneurship among economists seemed to lessen, we can identify a few exceptions. In this respect Joseph Schumpeter is probably the best known of the 
economists with an interest in entrepreneurship at the beginning of the $20^{\text {th }}$ century (Schumpeter, 1912; 1934). Schumpeter's idea was to build a new economic theory based on change and newness. His basic realization was that economic growth resulted not from capital accumulation, but from innovations or 'new combinations' that create a disequilibrium on the market. Another view of the entrepreneur in economic theory was found in the Austrian School of economic thought, represented by Carl Menger in the $19^{\text {th. }}$ century and further developed by Ludwig von Mises and Friedrich von Hayek in the $20^{\text {th. }}$ century. Today, the most prominent disciple of the Austrian tradition is probably one of Mises' students, Israel Kirzner (1973), who regards the entrepreneur as a person who is alert to imperfections on the market and is able to coordinate resources in a more effective way thanks to information about the needs and resources of different actors. Finally, we should mention the work by Frank Knight, who in his thesis Risk, Uncertainty and Profit (1916, revised 1921) made an important distinction between insurable risk and non-insurable uncertainty, arguing that entrepreneurial returns result from activities that cannot be predicted and that entrepreneurial competence is the individual's ability to deal with uncertainty.

In the mid-twentieth century, economics as a discipline became increasingly formalized and mathematically oriented - an approach that made it difficult to include the entrepreneur in the models of economics. However, in the 1940s, a number of scholars anchored in economic history began to take an interest in entrepreneurship as an empirical phenomenon. The effort was organized at the Research Center in Entrepreneurial History at Harvard University and led by Arthur Cole. The studies typically employed a Schumpeterian approach and focused on the modernization process of societies around the world. Among the most influential are Alexander Gerschenkron's study on the Soviet Union (1947) and David Landes'study on France (1949). However, after a couple of decades this stream of research lost momentum among economic historians, and scholars from psychology and sociology entered the field with an interest in the entrepreneur as an individual and started to study the key traits and the personality of the entrepreneur. The best known study in this respect is David McClelland's work The Achieving Society (1961), in which he argued that norms and values in a society, particularly with respect to the 'need for achievement', are of vital importance for economic development. The works by McClelland and others meant that the personal qualities of the entrepreneur occupied a prominent position in entrepreneurship research during the 1960 s and 1970s. 
One conclusion to be drawn is that entrepreneurship never attracted a large number of researchers nor became institutionalized within mainstream disciplines. This marginalization may partly be explained by a limited interest in entrepreneurship and small businesses in society. Economic development and dynamics were assumed to be based more on massproduction; large companies were seen as superior in terms of efficiency and the driving force behind technological development. The marginalization may also partly be explained by changes within mainstream disciplines. For example, economics became increasingly formalized and mathematically oriented, while economic history came to focus more strongly on 'business' history rather than the economic evolution of societies.

\section{The evolving field of entrepreneurship research}

However, the 1970s and 1980s were characterized by great economic and other changes in society. It was a period of 'creative destruction' in which new technologies were gaining ground, changes were taking place in the industrial structure, questions were being raised about the efficiency of larger companies, attitudes towards entrepreneurship and small business were evolving and there was increased political debate, supported by politicians such as Ronald Reagan in the USA and Margaret Thatcher in the UK. Against this background entrepreneurship and industrial dynamics became a more prominent theme.

From having been a rather marginal topic that only interested a few researchers in certain mainstream disciplines such as economics, economic history, sociology and psychology, many scholars from different fields, not least management studies, rushed into this promising field of research and started to elaborate on issues related to entrepreneurship and small businesses in a more systematic way. Entrepreneurship research since the 1980s can be described in terms of three phases: 1) take-off; 2) growth; and 3) a search for maturity. The phases include the development of the 'social dimension' of research, expressed in terms of the characteristics of the research community (e.g. organized fora for communication between scholars within the field, role models and positions at universities). The description also includes the 'cognitive dimension', which means the delimitation of the object of study and wide-ranging knowledge about the phenomenon as well as accepted methods and ways of reasoning.

The take-off phase: Pioneering studies on entrepreneurship 
At first, scholars interested in entrepreneurship picked up where the psychologists had left off - in the search for specific entrepreneurial traits and personalities. However, they were also interested in analysing entrepreneurship from several different angles. Given the newness of the field, it was easy for researchers from different fields to carry out research on entrepreneurship without experiencing obvious competence deficits - entrepreneurship was at that stage a 'low entry field'. It was a period when certain pioneering studies on entrepreneurship emerged that rendered the phenomenon 'visible'. In this respect, the seminal work by David Birch The Job Generation Process, published in 1979, should be mentioned. Birch showed that the majority of new jobs in the US were created by new and small firms not large established firms. The report had an enormous impact on the entrepreneurship research community, but also on policy-makers and politicians, as it provided an intellectual foundation for the incorporation of small businesses into the analyses of economic development.

In terms of the social dimension of the field, the research community can be characterized as rather fragmented and individualistic, i.e. the entrepreneurship researcher was to a considerable extent dependent on individual initiatives and projects. As a consequence, many initiatives were taken to stimulate communication within the rather fragmented and individualistic research community. During this period we can find a great many 'entrepreneurial' contributions from individual scholars to the creation of professional organizations, academic conferences and scientific journals within the field. For example, scholars, such as Karl Vesper at Babson College, were instrumental in forming an interest group on entrepreneurship within the Academy of Management, while on the European scene Josef Mugler at the Vienna School of Economics and Business Administration was important for the creation of the European Council for Small Business (ECSB). Karl Vesper, together with John Hornaday, launched the first Babson Research Conference in 1981, while Allan Gibb and Terry Webb organized the first Small Firms Policy and Research Conference in the UK. During the 1980s there was also an increase in the number of scientific journals within the field, for example, Journal of Business Venturing (with Ian MacMillan as founding editor), Entrepreneurship and Regional Development (with Gerald Sweeney as founding editor) and Small Business Economics (with Zoltan Acs and David Audretsch as founding editors).

The growth phase: Building an infrastructure and fragmentation of the research 
Since the early 1990s there has been an enormous growth in entrepreneurship research, which is obvious irrespective of the measurements employed. The social dimension of entrepreneurship as a research field was to a very large extent characterized by the building of a strong infrastructure in terms of a greater number of scientific journals and conferences, role models (e.g. chairs in entrepreneurship) and an increase in educational programmes and courses. For example, at the start of the new millennium, the infrastructure in the US included more than 2200 courses in entrepreneurship at over 1600 schools, 277 endowed positions, 44 English-language refereed journals and over 100 research centres (Katz, 2003). In this respect, a large number of scholars became instrumental in building an infrastructure at individual universities as directors of research centres and creators of education programmes in entrepreneurship as well as 'infrastructure builders' at international level, such as editors of international scientific journals and chairmen of professional organizations (Finkle and Deeds, 2001; Katz, 2003; Landström, 2005). According to Merton (1973), a strong infrastructure is important, not least as it creates 'academic autonomy'. That is, emerging fields need to legitimate themselves in the eyes of scholars from other fields, and different kinds of institution are essential for this purpose.

In the 1990 s there was not only large scale migration into the field, but the mobility of scholars in and out of the field was also quite extensive. As a consequence, the cognitive development of the field became highly fragmented, mainly consisting of atheoretical, empirical explorations of the phenomenon. Thus, Shane and Venkataraman (2000) argued that entrepreneurship research "has become a broad label under which a "hodgepodge" of research is housed' (p. 217), Low (2001) spoke about a 'potpourri' of entrepreneurship research (pp. 20-21) while Zahra (2005) described the field as only loosely connected and with 'a mosaic of issues to be explored' (p. 254).

\section{Searching for the maturity phase: Domain discussion and increased understanding of the} phenomenon

During the last decade, after almost 30 years of systematic study of entrepreneurship, the field has been searching for maturity, both in a social and a cognitive sense. As indicated, entrepreneurship has grown significantly as a research field and become a popular theme of interest among scholars from many different disciplines. As a consequence, over the last decade entrepreneurship as a research field has become more heterogeneous in character. To some extent different subgroups of scholars (or 'tribes') have emerged, and these 'tribes' 
work partly in different directions, thus creating a certain tension within the field. First, the seminal article by Shane and Venkataraman (2000) 'The promise of entrepreneurship as a field of research' triggered intense debate regarding how to define the domain of entrepreneurship research. In this debate we can find different arguments, from proponents who argue for the development of entrepreneurship research into a distinct domain of its own (domain approach) to those who advocate the integration of entrepreneurship with other fields, for example, strategic management (integrative approach), and scholars who argue that it is not possible to obtain a comprehensive entrepreneurship theory and that therefore scholars should actively divide themselves into more homogeneous communities studying specific topic areas, such as nascent entrepreneurship, venture capital, growth, etc. (multiresearch approach). Second, during the past decade, groups of scholars have broadened entrepreneurship as a phenomenon - from creating economic value to a broader range of value creation including social values (e.g. social entrepreneurship and entrepreneurship in the public sector). Finally, there are some scholars who argue for 'recreating' entrepreneurship as a research field (Hjorth, Jones and Gartner, 2008) and who stress, from a philosophical standpoint, the importance of addressing the social and cultural context in which entrepreneurship operates in addition to developing a closer relationship to 'the real world' with a stronger basis in the social and human sciences.

In the past decade we have also seen an increased theoretical focus within entrepreneurship research (Lohrke and Landström, 2010). In this respect entrepreneurship scholars have borrowed concepts and theories from mainstream disciplines, such as economics, psychology and sociology, and adapted them to the study of entrepreneurship. Importing theories from other fields of research is often a necessary first step towards a field that subsequently develops unique concepts and theories of its own, and in this respect, during the past decade we have seen entrepreneurship scholars launching and exploiting new concepts and theories in order to understand entrepreneurship, for example, Sarasvathy's 'effectuation' reasoning (2001) and Aldrich's evolutionary perspective (1999).

In conclusion, in this section we have shown that entrepreneurship research has a long tradition, beginning with individual achievements within mainstream disciplines such as economics, economic history, psychology and sociology. Since the 1980s entrepreneurship has grown significantly as a research field. As this paper focuses on 'the entrepreneurs' in entrepreneurship research, the above analysis indicates that we can find many different kinds 
of 'entrepreneur' who have been instrumental in the evolution of entrepreneurship as a research field: from the many pioneers who made the phenomenon visible in the 1980s, to scholars in the 1990s who played an important role in building an infrastructure within the field and more recently scholars who introduced new theoretical concepts and frameworks that will help us to understand entrepreneurship.

\section{METHODOLOGICAL APPROACH - BIBLIOMETRIC ANALYSIS}

As a complement to earlier historical reviews, in this study we have used bibliometric analysis to describe and understand the evolution of entrepreneurship as a field of research. In bibliometrics, various forms of citation analysis are based on the assumption that if a researcher cites a work, he/she has found it useful in some way, and therefore the more frequently a work is cited, the greater its role in the scholarly community (Garfield, 1972). This leads to the reinforcement and institutionalisation of certain opinions and, as a consequence, individual researchers end up playing a substantial role in the development of a research field (Crane, 1972). However, bibliometric analysis is not without limitations. For example, we have to bear in mind that it is based on the assumption that research is essentially cumulative - new research is built on and cites earlier high quality foundations - i.e. a 'normal science approach' (Kuhn, 1970). However, we know that this is not the only way to communicate and organize research, particularly in new and evolving fields that are organized and communicated through 'negotiations' between researchers and policy actors (Knorr Cetina, 1999; Åström and Sándor, 2009). In addition, there are concerns about the databases typically used for bibliometric analysis (Watkins, 2005) such as the Social Science Citation Index (SSCI) using the Web of Science. Although the SSCI is a wonderful resource for citation analysis, it has some limitations. The literature indexed in the databases is in favour of scholarly journals with less focus on conference proceedings. It is only now that Web of Science has started to index scholarly books. Other types of publications such as books are primarily found in databases of 'non source items', i.e. items in the reference lists of indexed journal articles not covered by the Web of Science databases. Furthermore, the coverage of journals varies greatly due to three factors: (1) the research field, where the social sciences are significantly less well-covered than medicine and the natural sciences, (2) the language and origin of the publications, where English and US-based journals dominate the databases, and (3) the age of the journal, as a period of time usually elapses between the launch of a journal and the point where Web of Science starts indexing it. Thus, citation databases such as Web 
of Science have limitations when analysing entrepreneurship research, as it is a relatively new and evolving field of research as well as being positioned within the social sciences.

\section{Methodological approach in the study}

We have used several different methodological approaches. The basis of the analysis is the 'handbooks' or state-of-the-art books published on entrepreneurship research and the core works cited in these were ranked using an index. We identified 135 core works, which constituted the basis of our analysis of citation patterns and employed the SSCI of the Web of Science in order to gain an understanding of how these entrepreneurship works are disseminated and used.

\section{Knowledge producers - methodology}

In an attempt to eliminate some of the major disadvantages of using generally available databases in bibliometric analysis, we exploited the fact that a number of authoritative contributions aimed at surveying the evolution of entrepreneurship research already exist. Since the 1980s, several 'handbooks' or state-of-the-art books have been published, containing commissioned surveys of the field or various topics of relevance to entrepreneurship. The chapters in these handbooks are generally written by experts and prominent scholars within the field, and it seems reasonable to assume that these authors will include references to the most important and relevant scholarly works. In this respect some works are referred to many times due to the fact that they are considered particularly important and could therefore be regarded as constituting the 'core knowledge' of the field. Thus, we assume that the subset of references referred to many times in the 'handbooks' constitutes the 'core works' of the field.

In order to identify these highly regarded works, we selected twelve handbooks with a total of 185 chapters on various aspects of entrepreneurship (Table 1). The twelve handbooks were chosen because they are generally highly regarded and together provide a reasonably balanced representation of the field. Since the early 1980s, Donald Sexton and colleagues (Kent, Sexton and Vesper, 1982; Sexton and Smilor, 1986; Sexton and Kasarda, 1992; Sexton and Smilor, 1997; Sexton and Landström, 2000) have published a state-of-the-art series on entrepreneurship research approximately every fifth year, in which core researchers describe the current knowledge within the field. This book series provided the basis for the selection of 
the five books included in our analysis. Likewise, Katz and Brockhaus (1993; 1995; 1997) undertook a similar task and have continued publishing volumes in the series, although these have become more focused on particular topics and methodologies, while Parker (2006) represents a new handbook with a broad overview of the field. In addition, we have included Acs and Audretsch's (2003) handbook, which represents a more explicit interdisciplinary profile. The same holds for Alvarez, Agarwal and Sorenson (2005), who also have a stronger focus on economics and small business economics, whereas Casson, Yeung, Basu and Wadeson (2006) represent more of an economics and economic history approach.

Insert Table 1 about here

We collected all the references cited in the handbook chapters in a database, a total of 12,781 references. The titles were checked individually and variations amended in terms of reference style and different editions, replacing a working paper with the later journal version or book chapter, etc. However, each title was only counted once within a chapter and repeated titles within a single chapter were removed (69 cases). The final database consisted of 12,712 references, of which 5,228 (41\%) were identical. However, half of the duplicate references $(2,722)$ were only cited two or three times, indicating a relatively low degree of influence.

In order to ensure a fair comparison of the number of references and taking into account when the work was published, we calculated and used an age-adjusted J-index (see Fagerberg, Fosaas and Sapprasert in this issue for a more detailed discussion). We selected the top one per cent of works on the J-index, equivalent to a value of 4.0. In this way we identified 135 works that could be regarded as the core literature within entrepreneurship research. The list of the 135 core works is presented in the Appendix 1.

In addition to the different rankings based on analyses of the references from the handbook chapters, we also explored the relation between the authors of the literature in the reference lists. Author co-citation analysis is a well established method for investigating the intellectual structure of the knowledge base in terms of research orientations within a larger field (White and Griffith, 1981). By defining how often works by different authors co-occur in the reference lists, we can map the intellectual structure of the field using co-occurrence 
frequencies as a measure of distance between authors, i.e. the more often two authors are cited together in the handbook chapters, the closer we can assume that they are related. This is done by using Bibexcel software (Persson, Danell and Schnedier, 2009), where co-citation frequencies and the strongest links within the set of authors selected for analysis are identified. In addition to the co-citation analysis based on relations between co-cited authors, we also used a clustering routine suggested by Persson (1994), where we scrutinised all pairs of co-cited authors, ranked by co-citation frequencies, looking for pairs that share one unit. For instance, if we have two pairs of co-cited authors, 'A and B' and 'B and C', these three authors form a cluster, whereas the pairs ' $\mathrm{A}$ and $\mathrm{B}$ ' and ' $\mathrm{C}$ and $\mathrm{D}$ ' do not. Thus, the clustering routine demands a higher level of connectivity and a multi-link connection between authors, rather than the single link co-cited pair connection. This information was exported to Pajek visualization software (de Nooy, Mrvar and Batagelj, 2005), where the Kamada and Kawai (1989) algorithm was used to produce a graphic representation of the intellectual structure of how the core knowledge in the field was used by the authors of the handbook chapters.

\section{Knowledge users - methodology}

The list of 135 core entrepreneurship works was the starting point for our analysis of knowledge users. In order to identify the knowledge users of the core literature, a search was conducted in Web of Science, using the 'Cited Reference Search' option. Based on a combination of title and authors, the citations of the top 135 core works up to 2008 were retrieved and saved in text format. In total, 54,469 documents citing the core works were found in the Web of Science databases. To obtain knowledge of where the core works are used, we analysed the following information, using Bibexcel software (Persson et al., 2009):

- The 'address field' of the articles was used to analyse the geographic location of the knowledge users.

- The name of the journals publishing the articles citing the core works was analysed to investigate where the knowledge users published their research.

- The Web of Science 'subject area' field was analysed, i.e. the categories developed by Web of Science to classify journals indexed by content, in order to investigate in what research fields the core literature was used. 
All three aspects were analysed by means of frequency rankings, and the subject areas by carrying out a co-occurrence analysis, conducted and visualized on the same principles as the co-citation analysis described above.

\section{Methodological reflections}

All studies have strengths and weaknesses. In this respect we will elaborate on a couple of concerns that need to be raised in order to evaluate the contribution of the present study.

It is important to bear in mind that history can be depicted from many different perspectives and that various aspects of history can be focused upon. For example, on the one hand, we can emphasize the cognitive dimensions of the evolution of entrepreneurship research, or instead look more closely at the social dimensions of the field. On the other, we can highlight the individual achievements that have been influential over time or focus more strongly on collective action taken by different groups of scholars within the field (see Aldrich in this issue). In the present study, using a bibliometric analysis, we have chosen to focus on the individual scholars who have made significant cognitive contributions to the evolution of the field.

The selection of 'handbooks' is critical for our results and conclusions. In order to identify other handbooks, a search was carried out on Google, Worldcat and in the Library of Congress Catalogue. However, we could find no other handbooks that took a general view of entrepreneurship, indicating that the twelve handbooks selected for our analysis represent a reasonable choice. However, it must be emphasized that we have only chosen general handbooks and not those that cover specific topics within the field, such as The Handbook of Qualitative Research Methods in Entrepreneurship, Handbook of Research on Ethnic Minority Entrepreneurship, Handbook of Venture Capital and Handbook of BioEntrepreneurship. The same holds for volume 4 and onwards of the titles published by JAI Press in the series Advances in Entrepreneurship, Firm Emergence and Growth. As a consequence of the use of this broad selection of general handbooks, we can expect to find a wide selection of scholars with different disciplinary backgrounds, writing in a range of journals and 'subject areas' compared to bibliometric studies using more narrow approaches, for example, using specific management and entrepreneurship journals as the basis for their analysis (e.g. Shane, 1997; Crump, Abbery and Zu, 2009). In addition, we have conducted a robustness test, comparing the citation structures in the handbooks with those in 
entrepreneurship journal articles indexed in the Web of Science databases. These analyses revealed substantial similarities in terms of citation structure when comparing the two forms of entrepreneurship research publications: the age of the references showed only minor variations between the two publication forms, while an author co-citation analysis of the top 120 most cited authors linked the same authors in both datasets to a substantial degree. When analysing the overlap of cited authors on a more comprehensive level, at least $50 \%$ of the cited authors were the same, while variations were primarily found among authors with few citations (Åström, 2011).

We checked the importance of the authors of the handbook chapters in order to satisfy ourselves that they can be regarded as experts and prominent scholars within the field. To do this, we analysed whether they were members of the editorial boards of the leading entrepreneurship journals (such as Journal of Business Venturing, Small Business Economics, Entrepreneurship Theory and Practice, Journal of Small Business Management, Entrepreneurship and Regional Development and Strategic Management Journal). The share of editorial board members among the authors of the chapters in the handbooks was generally high, in the range of $68-80 \%$. We found a lower proportion of authors on editorial boards in the early handbooks edited by Sexton, Kent et al. (1982) (28\%), Sexton and Kasarda (1992) (49\%) and Sexton and Smilor (1997) (44\%) as well as the handbooks edited by Casson et al. $(33 \%)$ and Parker (32\%). However, as the latter two have a more multidisciplinary focus, it seems reasonable that many of the authors were not members of the editorial boards of entrepreneurship journals.

Finally, we must be aware of the characteristics of handbook references. Authors of the chapters are often asked to be inclusive in their research reviews and therefore include their own works that might be of less importance. In addition, works that synthesize and are important for the evolution of the field (e.g. works that define central concepts) tend to be over-represented in such state-of-the-art reviews and also have a self-citation tendency, i.e. authors of handbook chapters tend to cite chapters in previous handbooks.

\section{KNOWLEDGE PRODUCERS IN ENTREPRENEURSHIP RESEARCH}

In this section we will elaborate on the knowledge producers and core works of entrepreneurship research. In order to answer the first research question: 'Who are the leading 
knowledge producers within the field?', in the first two subsections we will focus on the authors of the core works in entrepreneurship. Initially, we conducted an analysis of all 12,712 references in the entrepreneurship research handbooks. From the analysis we identified the 20 top-ranked scholars within the field, who will be presented in the second subsection. We then turned to the second research question focusing on the core works of these influential scholars in entrepreneurship research, and in the third subsection the analysis focused on the 135 works that constitute the top one per cent of references in the handbooks. Finally, in a separate subsection, the 20 top-ranked works are described in detail.

\section{References in entrepreneurship research handbooks}

Of the twelve handbooks, two were published during the 1980s, five in the 1990s and five in the early 2000s. In order to identify the most influential scholars during each decade, we focused on an 'author co-citation analysis' that helped us to identify clusters of core scholars over time. The analysis revealed some interesting knowledge development paths within entrepreneurship research, and in this section we will elaborate on these changes over time.

Insert Figure 1a about here

Two clusters of scholars were identified in the 1980s (Figure 1a).

- Cluster 1 (yellow circles): Pioneers in entrepreneurship research during the 1980s. During this decade a large number of entrepreneurship research pioneers emerged, a rather eclectic cluster that includes scholars such as Cooper, Vesper, Roberts, Shapero, Brockahus, Bruno, Hornaday, Birch and Timmons - almost all of US origin, indicating the strong US tradition in entrepreneurship research.

- Cluster 2 (green circles): Classical scholars rooted in economics and psychology. It is obvious that at this stage entrepreneurship research was highly anchored in economics and psychology. This cluster includes scholars from different disciplines who made early contributions to our knowledge of entrepreneurship, e.g. Schumpeter, Leibenstein, Kilby, Knight, Kirzner, Redlich, Baumol and Cole in economics, and McClelland, Winter and Aboud in psychology. 
In the 1990s the focus of entrepreneurship research changed, and the number of clusters increased, indicating greater heterogeneity (Figure 1b). In addition, the clusters illustrate the transformation of entrepreneurship research that occurred during the 1990s, from a trait-based to a more behavioural approach.

Insert Figure $1 \mathrm{~b}$ about here

- Cluster 1 (yellow circles): Scholars with an individual focus but also an emerging behavioural interest. In this cluster we can detect the transformation from an individual focus (represented by the strong nodes of Carsrud, Brockhaus and Sexton) to a more 'entrepreneurial behaviour' interest (represented by the nodes of Vesper, Stevenson, Timmons and Bygrave).

- Cluster 2 (green circles): Scholars with a strong anchor in mainstream disciplines, such as sociology, in which Aldrich represents a very strong node in entrepreneurship, as well as, in which Cooper and the group around him became important. It is interesting to find a strong group of scholars researching the importance of venture capital in entrepreneurial ventures (represented by MacMillan).

- Cluster 3 (red circles): Scholars with a focus on 'small business economics'. A small cluster comprising empirical studies on the importance and dynamics of new and small ventures, represented by Birch, Phillips and Kirchhoff, and Storey.

The 2000s witnessed more changes in the characteristics of entrepreneurship research and the scholars seemed to form one large and two smaller clusters (Figure 1c).

Insert Figure 1c about here

- Cluster 1 (yellow circles): Entrepreneurship scholars anchored in management studies. This is a very large and rather eclectic cluster with many 'key nodes'. It includes scholars who are regarded as core authors within the field, for example, Aldrich, 
Shane, Venkataraman, Gartner, Acs and Audretsch. In particular, it is interesting to note the increased theoretical emphasis in entrepreneurship research, for example, in this cluster we find theoretical contributions from Barney, Cohen and Levinthal, Nelson and Winter, Hannan and Freeman, Williamson, Porter and Penrose.

- Cluster 2 (green circles): Entrepreneurship scholars anchored in economics. The increased interest in entrepreneurship among scholars rooted in economics during the 2000 s is reflected by a fairly small cluster including Storey, Evans, Holtz-Eakin, Leighton, Parker, Blanchflower and Wright.

- Cluster 3 (red circles): Scholars in the area of venture capital and financial economics emerged more strongly from cluster 2 in the 1990s and formed a separate cluster. This small cluster is made up of financial economics scholars with an interest in venture capital, such as Amit, Gompers, Lerner and Jensen.

In conclusion, as can be seen from Figures 1a, 1b and 1c, entrepreneurship seems to be a rather changeable field of research, as few scholars appear to maintain their influence over a longer period of time. Apart from Schumpeter, only Arnold Cooper, Howard Aldrich and Donald Sexton (perhaps due to his editorship of several handbooks) are included in the clusters in all three decades. It is also interesting to note that over time, the structure of the maps presents networks that move increasingly closer to each other. This could be an effect of the greater use of a knowledge-base situated within the field itself rather than classics from other fields. For example, from the 1990s, the structure of these maps represents specialization within the field itself rather than classics from other fields or early pioneers of entrepreneurship research. This could be interpreted to mean that entrepreneurship is becoming more formalized as a field, with its own research specialities and the establishment of 'in-field' core knowledge, indicating an increased convergence also shown by Cornelius, Landström and Persson (2006) and Grégoire, Noël, Déry and Béchard (2006).

\section{Top-ranked scholars in entrepreneurship research}

To be able to further elaborate on the first research question: 'Who are the leading knowledge producers in entrepreneurship research?', Table 2 ranks the top 20 scholars on the basis of their total contribution to the list of the 135 works in our database, i.e. their contribution to the field based on the overall J-index of their various titles within the core literature. The ranking includes both the main author and co-authors, and we used a ratio of co-authorship that takes 
into account the number of co-authors included in each work, i.e. in works that include two authors, each author received a 50\% share of the J-index and SSCI citations. In this way we strengthened the importance of single authorship.

The most influential scholars within a field typically publish several important contributions. Table 2 reveals that several top-ranked authors have made a number of contributions to the core works in entrepreneurship. For example, authors like Howard Aldrich and William Gartner have as many as 6 and 5 contributions respectively in the list of 135 core works, whereas six authors received their rankings based on a single work (Knight, Bhidé, McClelland, Storey, Casson and Saxenian).

Insert Table 2 about here

We argue that among the top-ranked scholars in entrepreneurship, some are extremely important and frequently cited in mainstream disciplines in general, not just in entrepreneurship. If we use the list of the 135 core works identified in the Appendix and calculate the ratio of each top-ranked scholar's total citations in SSCI in relation to the Jindex $^{1}$ (see Table 2), it is obvious that the top-ranked scholars can be divided into two groups; the first is 'mainstream discipline researchers' with a high ratio, indicating that their impact (reflected by the total SSCI citations) is high in comparison to their internal influence in entrepreneurship (reflected by the J-index). This group includes top-ranked scholars such as Schumpeter (with a ratio of 83.08), Knight (112.56), McClelland (226.58), Barney (125.63), Porter (349.27) and Saxenian (113.92). The other group can be regarded as 'entrepreneurship researchers' and their ratio is, in general, less than 20. The only exception is David Storey with a ratio of 40.76 . However, we have decided to regard him as an 'entrepreneurship researcher' as he has, over time, published extensively on entrepreneurship and small businesses and been very influential within the field.

Thus, we can identify fourteen scholars who stand out as being the most influential 'entrepreneurship researchers'. The most highly ranked, with a J-index of over 20, are

1 ( $\sum$ SSCI Citations $/ \sum$ J-index $) /$ Number of core works on entrepreneurship by the author 
William Gartner, Howard Aldrich, Israel Kirzner, Scott Shane and Sankaran Venkataraman. In general, these scholars have published several core works over a long period and have all shown a long-term interest in entrepreneurship. Researchers with a J-index of 15.00 to 19.00 include William Baumol and David Audretsch, both with a long-standing interest in entrepreneurship. Finally, there is a group of core researchers with a J-index of 10.00 to 14.00, including David Birch, Amar Bhidé, David Blanchflower, David Storey, Mark Casson, Josh Lerner and David Evans - who in many cases have only published one or two heavily influential works in the field.

In order to gain an understanding of the careers of these fourteen most influential entrepreneurship researchers, we conducted an analysis of their curricula vitae (CVs). One of the great advantages of studying the careers of researchers is the near universal reliance on the $\mathrm{CV}$, as it functions as a personal advertisement, which gives the researchers a strong incentive to provide timely and accurate data (Cañibano and Bozeman, 2009). The data included in the $\mathrm{CVs}$ reflect changes in interests, jobs and collaboration, making the $\mathrm{CV}$ a rich source of longitudinal data (Dietz et al., 2000; Bozeman, Dietz and Gaughan, 2001). At the same time, analysis of CVs as a data source is not unproblematic. For example, the information is selfreported and thus subjective in nature. In addition, the CV has a semi-structured and nonstandardized format and may lack valuable information, which makes comparisons and analysis difficult (Dietz et al., 2000). Despite the disadvantages, the potential of the CV as a research tool is enormous, but it has rarely been used as a basis for research. A summary of the CVs of the fourteen 'entrepreneurship researchers' is presented in Appendix 2.

In the CVs of top-ranked scholars in entrepreneurship research we looked at their (a) career trajectories, (b) mobility and (c) scientific productivity (Table 3).

Insert Table 3 about here

Entrepreneurship is generally regarded as a research field closely connected to practice. Therefore, it is somewhat surprising to find that the top-ranked scholars seem to lack extensive industrial experience. Birch and Evans are the exceptions, as both have long experience of working in industry, although their industry careers started after they published 
their core works in entrepreneurship. Most of the top-ranked scholars have made an impressive and rapid career in the academic system. On average, they obtained their $\mathrm{PhD}$ at the age of 29 years (Casson was only 24 years old) and became full professors at the age of 39 (with Baumol being the youngest full professor at 27 years). It is also interesting to find that the top-ranked scholars in entrepreneurship are heavily rooted in a mainstream discipline, primarily economics but also sociology and the broader field of management studies, and few have changed their disciplinary focus over time. The fact that they are strongly rooted in their mainstream discipline is also reflected in their generally high age when they published their first major contribution to entrepreneurship research, i.e. their first work included in our list of 135 core works in entrepreneurship - the average age being 40 years with a range from 32 (Gartner) to 47 years (Storey).

When analysing the mobility of the top-ranked scholars, we find that it is rather low between universities, and only Baumol, Audretsch and Blanchflower have moved from one country to another. On average, after obtaining their $\mathrm{PhD}$ degree, the scholars moved from one university to another 3.3 times in their careers. On the other hand, eight out of fourteen reported receiving visiting professorships, the average number being 2.6, including a broad range of universities around the world.

The scientific productivity among the top-ranked scholars in entrepreneurship is extensive. On average, they have published almost 114 scientific works (including books, edited books, book chapters and refereed journal articles, but excluding conference papers and other reports). The high scientific productivity is not due to a large number of co-authorships, as in many cases the scholars are the sole author of the articles, with a single to co-authorship ratio of 0.50 , indicating that almost five out of ten articles were written solely by the top-ranked scholars themselves. It is also interesting that books seem to play an important role in their publication strategies. Not only are many of their most highly cited works 'books', but in terms of quantity they have also published a large number - on average 7.4 - with Casson, Audretsch and Shane as the most productive scholar in this respect with more than ten books each.

\section{Core works in entrepreneurship research}


In this section we will address our second research question: 'What core works can be identified in entrepreneurship research?' We will base our analysis on the top 135 core works. In this subsection we will describe these works with regard to age distribution, publication format, geographic distribution of the research and insider versus outsider works within the research field.

From the list of 135 core works, it is obvious that entrepreneurship is a fairly young research field. Of the 135 core works, 113 (84\%) have been published since 1980 (Table 4). As the number of publications in entrepreneurship has increased enormously over time, it is important to relate the frequency of core works to that of publications. If related to the number of titles in the sample database cited more than once (duplicates), it is obvious that the field relies heavily, on the one hand, on some 'classic' works published before the 1980s and, on the other, on recent contributions mainly published in the 2000s. In Table 4, a ratio of the core works in relation to duplicate titles (i.e. not the whole initial database, as duplicates are considered a measure of the importance of a citation) is presented.

Insert Table 4 about here

Of the 135 core works, 49 (36\%) consist of books and book chapters, 81 works were published in scientific journals and 5 as reports. A closer look at the journal publications reveals that the Journal of Business Venturing (JBV) heads the field (with 15 out of 81 journal articles), followed by a couple of rather theoretically oriented journals within management science (Academy of Management Review and Administrative Science Quarterly), economics (American Economic Review) and the social sciences (Journal of Political Economy and American Journal of Sociology). The results indicate that books play an important role in the social sciences, perhaps because a book-length exposition is needed in order to set out new theoretical contributions in an emerging field.

Scholars from the US dominate the field of entrepreneurship research, as revealed by the Jindex (and adjusting for co-authorships). US scholars constitute $84.6 \%$ of the total J-index of the 135 core works, their counterparts in Europe $15.2 \%$ and Asian scholars a mere $0.2 \%$. The US dominance is also reflected in the top ranked institutions in the area of entrepreneurship 
(Figure 2). The affiliation of all authors of the core works has been investigated. Affiliation corresponds to one year prior to the publication of the work and co-authorship has been taken into account. The calculation in Figure 2 indicates that there does not seem to be a main centre of entrepreneurship research. One exception is Harvard Business School with a number of scholars contributing to the core works in entrepreneurship (e.g. Bhidé, Stevenson, Gompers, Lerner, Sahlman, Kanter and Porter) and to some extent Stanford University (with scholars such as Hellmann, Eisenhardt, Hannan and Arrow). Apart from that, most top research institutions in entrepreneurship are represented by one or a few scholars, for example, Kirzner and Baumol at New York University, Aldrich at the University of North Carolina, Gartner at Georgetown University, Shane at Maryland University, Saxenian, Freeman and Teece at the University of California, and Audretsch at the Wissenschaftszentrum Berlin für Sozialforschung (WZB).

Insert Figure 2 about here

In order to obtain a sense of the importance of insiders versus outsiders within the field, we calculated the ratio between 'SSCI citations per year' and the 'J-index' for each core work. A ratio above 2.00 was regarded as indicating an 'outsider', i.e. a scholar cited by entrepreneurship researchers but who is even more heavily cited by researchers from other fields of research (indicated by a much higher number of 'SSCI citations per year') in relation to the work's importance in entrepreneurship research (as reflected by its J-index). The publication years of the outsider and insider works are presented in Table 5.

Insert Table 5 about here

Table 5 indicates that 14 outsider works in entrepreneurship research were published prior to the 1980s, whereas few insider works were published during this period, an outsider/insider ratio of 1.75 . However, the 1980s saw an increase in the number of insider works that have been influential in entrepreneurship research but did not receive much attention outside of the field (reflected in a high J-index but not a high number of SSCI citations per year; during the 
period in question the outsider/insider ratio was 0.38). The 1980s can be regarded as a pioneering phase with many works that opened up the field and received a great deal of attention in various handbooks.

In the 1990s we find a mix of outsider and insider works. The number of insider works published during the decade increased compared to the $1980 \mathrm{~s}$, but there was also a significant increase in the number of outsider works (ratio 0.75). The field grew due to the migration of scholars from other research fields. Looking at the characteristics of the outsider works, we find an inflow of works anchored in disciplines such as economics (e.g. Storey, 1994; Blanchflower and Oswald, 1998; Audretch, 1995; Acz and Audretsch, 1990; Baumol, 1990), financial economics (e.g. Gompers and Lerner, 1999; Berger and Udell, 1998; Sahlman, 1990), economic geography (e.g. Saxenian, 1994; Audretsch and Feldman, 1996; Jaffe, Trajtenberg and Henderson, 1993; Glaeser, Kallal, Scheinkman and Shleifer, 1992; Krugman, 1991) and strategic management (e.g. Cohen and Levinthal, 1990; Barney, 1991; Teece, Pisano and Sheen, 1997; Porter, 1990) - works with a broader audience and to some extent anchored in disciplines with a slightly different publication pattern to that of entrepreneurship research.

Finally, in the first three years of the 2000s, the ratio of outsider/insider works was only 0.11 , indicating an increased number of insider works (the only outsider works published between 2000 and 2002 were Sorenson and Stuart (2001) and Carroll and Hannan [2000]). However, the results may be influenced by the fact that it often takes some time to receive a high number of SSCI citations, and several of the works published in the early 2000s might not yet have had the possibility to receive a large number.

\section{Top-ranked works in entrepreneurship research}

In order to further elaborate on the core works in entrepreneurship research, we will focus on the 20 top-ranked works in entrepreneurship research presented in Table 6.

Insert Table 6 about here 
We have divided the top-ranked works into thematic groups based on content:

- Contribution to the theoretical foundation works, focusing on

- The function of entrepreneurship in the creation of new markets

- The characteristics of the entrepreneur as an individual

- The evolution of entrepreneurship and the entrepreneurial process

- Domain-defining works

- Empirical studies of entrepreneurship and small businesses

\section{Theoretical foundation works}

Out of the 20 top-ranked works, as many as thirteen can be regarded as theoretical foundations of entrepreneurship anchored in economics and in 'the function of entrepreneurship in the creation of new markets' (Schumpeter, 1934; 1942; Kirzner, 1973; 1997; Knight, 1921; Casson, 1982; Shane, 2000) as well as in the behavioural sciences and 'the characteristics of the entrepreneur as an individual' (McClelland, 1961). There are also theoretical foundations related to the understanding of 'the evolution of entrepreneurship and the entrepreneurial process' (Stinchcombe, 1965; Penrose, 1959; Nelson and Winter, 1982; Aldrich, 1999; Aldrich and Zimmer, 1986).

The function of entrepreneurship in the creation of new markets

From the list of core works in entrepreneurship with a theoretical focus, a couple are rooted in economics that elaborate on the function of entrepreneurship in the creation of new markets. In this respect, different schools of economic thought as a foundation of entrepreneurship research can be identified, such as the Schumpeterian, Kirznerian, Knightian and 'integrative' schools (Landström and Benner, 2010).

- The Schumpeterian school

Joseph Schumpeter is the best known economist with an interest in entrepreneurship. Throughout his career he tried to formulate an economic theory built on change and 'newness' and was the first to treat innovation as an endogenous process - with the entrepreneur as an innovator and prime mover in the economic system, who leads the market away from existing equilibrium positions and drives it to a higher one (Van Praag, 2005). It is obvious that Joseph Schumpeter's works (1934 and 1942) can be regarded as some of the most influential entrepreneurship contributions. Schumpeter's book The Theory of Economic 
Development (1934), in which he lays the foundation of his argumentation, is top ranked in our analysis with a J-index of 33.51. Schumpeter's second contribution to the top-20 list is Capitalism, Socialism and Democracy (1942), which is ranked $5^{\text {th }}$ in our analysis (J-index 13.51). In this book he focused on the institutional structure of society and argued that increased rationality in society weakens entrepreneurship and leads to the stagnation of capitalism. Due to economies of scale, large corporations have an innovative advantage over small firms and the economic landscape is dominated by giant corporations.

D The Kirznerian school

Without doubt, Schumpeter's view of the function of the entrepreneurial process has been predominant in entrepreneurship research for many years. However, the Austrian economic tradition has received much attention during the past decade, not least after the domain defining article by Shane and Venkataraman in 2000 (see below). Today, the most prominent exponent of the Austrian tradition is Israel Kirzner, and several of his works are included in the top ranked entrepreneurship literature, such as his book Competition and Entrepreneurship (1973), which is ranked $8^{\text {th }}$ in our analysis (J-index 11.89). According to Kirzner, it is fundamental for an entrepreneur to be alert in identifying and dealing with profit-making opportunities ('entrepreneurial alertness'). He/She searches for imbalances in the market system. In such situations, there is an asymmetry of information in the market, which means that resources are not effectively coordinated. By seeking out these imbalances and constantly trying to coordinate resources in a more effective way, the entrepreneur leads the process towards a new equilibrium.

In addition, two other works related to the Kirznerian way of thinking are included among the top-ranked works in entrepreneurship research. First, Kirzner's article "Entrepreneurial discovery and the competitive market process: An Austrian approach", published in the Journal of Economic Literature in 1997 (rank 11, J-index 11.46), in which he conducts a survey of Austrian economics and clarifies some of his own arguments regarding mainstream microeconomics in general and the entrepreneurial discovery process in particular. Second, in relation to the Austrian tradition of economic thought, we also include the article by Scott Shane on 'Prior knowledge and discovery of entrepreneurial opportunities' in Organization Science (2000), which is ranked $3^{\text {rd }}$ in our analysis (J-index 16.22). In the article, Shane conducted an empirical test of some assumptions in Austrian economics and demonstrated that any given technological change in society will generate a range of entrepreneurial 
opportunities that are not obvious to all potential entrepreneurs and that any given entrepreneur will discover only those opportunities related to his or her prior knowledge.

\section{- The Knightian school}

A third function of entrepreneurship is the entrepreneur as 'risk-taker', a theme addressed by Frank Knight in his thesis Risk, Uncertainty and Profit (1916/1921). The work is very highly ranked in $4^{\text {th }}$ position with a J-index of 15.68. In his book, Knight made a distinction between insurable risk and non-insurable uncertainty, arguing that opportunities arise out of uncertainty related to change and that an entrepreneur receives a return for making decisions under conditions of 'true' uncertainty - if change is predictable, there is no opportunity for profit. Knight's work has been highly influential in entrepreneurship research, primarily in the context of different occupational choice models (e.g. Lucas, 1978; Kihlstrom and Laffont, 1979) and more recently regarding decisions made in entrepreneurial ventures (e.g. Sarasvathy, 2001).

- The integrative approach

For many years there has been little room for entrepreneurship in mainstream economics, or as William Baumol argued 'The theoretical firm is entrepreneur-less - the Prince of Denmark has been expunged from the discussion of Hamlet' (1968, p. 68). During recent decades, several attempts have been made to include entrepreneurship in economic modelling and analysis. One such attempt that has been important is by Mark Casson in his book The Entrepreneur: An Economic Theory (1982), which in our analysis is ranked $12^{\text {th }}$ with a Jindex of 11.38. In the book, Casson synthesizes the relationship between the entrepreneurial market-making process and neo-classical economics. In line with the arguments of the Austrian economic tradition, he recognizes that individuals differ not only in their tastes but also in their access to information. As a result, the entrepreneur will make superior judgemental decisions about the coordination of scarce resources that differ from those of other people, seeing entrepreneurship as an intermediation, or 'market-making', process.

\section{The characteristics of the entrepreneur as an individual}

In the late 1950s and early 1960s, a series of large-scale studies were conducted in an effort to understand the personal traits and characteristics of the entrepreneur: these were mainly carried out by behavioural scientists from disciplines such as psychology and sociology. One of the most influential works in this respect is David McClelland's study The Achieving 
Society (1961) (ranked $9^{\text {th }}$, J-index 11.89). McClelland posed the question: 'Why do certain societies develop more dynamically than others?' and demonstrated the link between the need for achievement in society and economic development. In this respect, entrepreneurs become an important driving force in the development of a society - the need for achievement is transformed into economic growth through the medium of the entrepreneur. McClelland's contribution meant that the personal qualities of the entrepreneur occupied a prominent position in entrepreneurship research during the 1970s and 1980s. However, over time, such research was subject to criticism and eventually came to be regarded as something of a 'dead end'.

$\underline{\text { The evolution of entrepreneurship and the entrepreneurial process }}$

The creation of evolutionary models accelerated during the 1970s, mainly as a result of the open-system revolution in organization theory. Within a short period, scholars in different disciplines presented evolutionary theories, inspired in some cases by the seminal work of Donald Campbell (1965), who attempted to explain phenomena ranging from the micro to macro levels of an organization. For example, on the theory of the firm, Richard Nelson and Sidney Winter (1982) were pioneers in the application of evolutionary models of economic change - although perhaps less inspired by Campbell and more by the Carnegie School of routine-based models of organizational action. These authors were also inspired by Schumpeter, who was a prominent exponent of the idea that economic change could be conceptualized as an evolutionary process (Fagerberg, 2002).

In our analysis, Richard Nelson and Sidney Winter's book Evolutionary Theory of Economic Change (1982) is ranked $18^{\text {th }}$ with a J-index of 9.58. The book summarizes a series of papers by Nelson and Winter in the 1970s, in which they tried to develop formal models of economic evolution as well as answer the basic question of how firms and industries change over time. In line with Schumpeter, they focused their interest on technological change in the economy, arguing that technological competition is the driving force of economic growth. In their attempts to build a model of evolutionary changes in organizations, Nelson and Winter relied on the Carnegie School of 'bounded' and 'procedural' rationality in organizations (e.g. Simon, 1959; 1965; Cyert and March, 1963).

What Nelson and Winter did at a micro economic level, Howard Aldrich (1979) did at an organizational behaviour level. He argued that organizations flourish or fail because they are 
more or less suited to the particular environment in which they operate. His book on Organizations Evolving (1999) (ranked 20 ${ }^{\text {th }}$, J-index 9.38) provides a conceptual framework based on an evolutionary approach to new firm formation. Here, Aldrich attempts to explain why and how new ventures develop using four generic processes - variation, selection, retention and struggle - which are necessary for and allow the evolution of new ventures. Among the highest ranked works within the field of entrepreneurship is another contribution by Howard Aldrich; Aldrich and Zimmer's chapter on 'Entrepreneurship through social networks' in a handbook edited by Sexton and Smilor in 1986 (ranked $13^{\text {th }}$, J-index 10.90). In this conceptual chapter, Aldrich and Zimmer take an evolutionary perspective in order to introduce a view of entrepreneurship as embedded in networks of relationships and show the necessity for entrepreneurs to seek and employ social ties in order to attract resources and compete in markets.

In line with the evolutionary argumentation, we can also add Arthur Stinchcombe's seminal book chapter on 'Social structure and organization' (1965) (ranked $16^{\text {th }}$, J-index 9.73), in which he introduced the concept of the 'liability of newness'. Stinchcombe argued that there are significant differences in survival probabilities between established and young firms and that a new venture will experience the liability of newness, as (1) individuals in a young venture face challenges learning new roles; (2) there is a lack of defined routines and standardized procedures; (3) there is a lack of trust among new-venture employees; and (4) there is a lack of critical and stable external ties.

Most research to date has focused on external issues related to the liability of newness, rather than internal aspects that may influence the evolution of new ventures (Nagy and Lohrke, 2010). However, one 'internal' approach is the resource-based view (RBV), in which a firm's competitiveness is enhanced by the extent to which it can develop and maintain control over its resources or capabilities. One pioneering contribution within this framework is Edith Penrose's work on The Theory of the Growth of the Firm in 1959 (ranked 17 ${ }^{\text {th }}$, J-index 9.73). In her book, Penrose intended to create a theory of firm growth, but most attention has been paid to her perhaps unintentional contribution to the resource-based view. Central to Penrose's argument is the view of the firm as an administrative unit with control over a number of potentially valuable resources, and she emphasizes the importance of managerial (administrative and entrepreneurial) capabilities in the growth of the firm. 


\section{Domain-defining works}

In new fields, there is often an ongoing discussion concerning the domain of research, and this has certainly been the case among entrepreneurship scholars. At different points in time, we can find highly influential contributions on this subject. In the late 1980s, interest in the characteristics of the entrepreneur as an individual gathered momentum. In this respect, the works of William Gartner became important, not least his article "Who is the entrepreneur? is the wrong question" in 1988 , which is ranked $6^{\text {th }}(\mathrm{J}$-index 12.82$)$ in our analysis. In this article, Gartner questioned the prevailing focus in entrepreneurship research on the characteristics of the entrepreneur, instead viewing entrepreneurship as a set of activities involved in the creation of new organizations. This article (together with a couple of later articles in a similar vein e.g. Gartner, 1990; 1993) can be seen as the start of a shift from a focus on the entrepreneur to an increased interest in behavioural and process-related aspects.

About a decade later, a new domain-defining discussion emerged based on Scott Shane and Sankaran Venkataraman's influential article on 'The promise of entrepreneurship as a field of research' published as a 'research note' in Academy of Management Review in 2000 - an article that is highly ranked in our analysis (ranked $2^{\text {nd }}, \mathrm{J}$-index 22.97 ). In the article, which draws on the work by Venkataraman (1997) (ranked 15 ${ }^{\text {th }}$, J-index 10.42), the two authors discussed the domain of entrepreneurship research and triggered several developments within the field: (1) the article created a renewed interest in the Austrian school of economics, as Shane and Venkataraman anchored their argumentation in the works of Kirzner $(1973 ; 1997)$; (2) the article became a driving force that focused research interest on 'business opportunity recognition'; and, not least, (3) the article triggered intense debate regarding the definition of the domain of entrepreneurship research, a debate that has continued up to the present.

\section{Empirical studies of entrepreneurship and small businesses}

In evolving fields of research it is always important to gain a systematic and rigorous understanding of the phenomenon under study. Much research in entrepreneurship during the 1980s and 1990s focused on empirical investigations of different aspects of entrepreneurship and small businesses. Among the top 20 core works in entrepreneurship we find three contributions that try to illuminate the decision to become self-employed (Hamilton, 2000), to understand the survival and growth of the entrepreneurial venture (Bhidé, 2000) and to provide a synthesized understanding of the small business sector (Storey, 1994). Furthermore, we know that 'context' is important for entrepreneurship and within the top-ranked works we 
find one empirical study in the regional context of Silicon Valley and Route 128 in the US (Saxenian, 1994).

Barton Hamilton discussed the decision to become an entrepreneur in his article 'Does entrepreneurship pay? An empirical analysis of the returns to self-employment' in the Journal of Political Economy (2000). In our analysis the article is ranked $19^{\text {th }}$ with a J-index of 9.46. In order to understand the motives for becoming self-employed, the article examines differences in the earning distributions of self-employed individuals and paid employees. Based on a large panel database in the US, Hamilton concluded that the non-pecuniary benefits of self-employment are substantial. Most entrepreneurs enter and persist in business despite the fact that they have both lower initial earnings and lower earnings growth than paid employees.

Among the top-ranked works in entrepreneurship we also find a contribution that tries to understand the survival and growth of entrepreneurial ventures. In the book The Origin and Evolution of New Businesses by Amar Bhidé (2000), which is ranked $7^{\text {th }}$ with a J-index of 12.16, the author conducted an empirical analysis of the nature of the opportunities pursued by entrepreneurs, the problems they face in the creation and evolution of the entrepreneurial venture and their contributions. The book focuses on the original conditions of new ventures, and an interesting conclusion is that many successful new ventures on the Inc. 500-list started without any innovative idea or significant external finance.

David Storey's book Understanding the Small Business Sector published in 1994 (ranked $10^{\text {th }}$, J-index 11.63) can be regarded as the most comprehensive synthesis of our knowledge of the small business sector. The book has its origins in a major research programme on small businesses in the UK, financed by the Economic and Social Research Council (ESRC). Storey was appointed Programme Co-ordinator of the research programme that was conducted between 1989 and 1992. The book is more or less a summary of the knowledge acquired within the research programme on issues such as the birth, growth and death of small firms, the rate of employment within the sector as well as the regional distribution of small businesses and provides carefully considered conclusions from a policy perspective.

Silicon Valley has long been regarded as a highly successful entrepreneurial region, and politicians around the world have tried to copy its characteristics. In her book Regional 
Advantage: Culture and Competition in Silicon Valley and Route 128 (1994), ranked $14^{\text {th }}$ with a J-index of 10.85, AnnaLee Saxenian contrasts the cultures of Silicon Valley and Route 128 outside Boston. The detailed chronological case stories of the two leading high-tech regions in the US are related to the role of innovation-based competition, but also to the importance of cultural-institutional aspects of technology-based clusters. The conclusion is that the success of Silicon Valley is structural rather than specific and that it is necessary to create a culture and modes of action that support the overall development of a region.

\section{Some concluding remarks}

The conclusion that can be drawn from this review of the top-ranked works in entrepreneurship research is that the theoretical development of the field seems to have been rather slow. While some of the most influential empirical works were produced during the 1990s and early 2000s (Storey, 1994; Saxenian, 1994; Hamilton, 2000; Bhidé, 2000), in a theoretical sense the field is based on imported theories from mainstream disciplines, such as Schumpeter (1934; 1942), Kirzner (1973), Knight (1916) and Casson (1982) who are anchored in economics, as in the original McClelland (1961) in the behavioural sciences. Several works are based on an evolutionary view of the firm (Stinchcombe, 1965; Penrose, 1959; Nelson and Winter, 1982; Aldrich, 1999).

As has been shown in our earlier cluster analyses of core authors in entrepreneurship research (pp. 9 and 17), theoretical interest in entrepreneurship research has increased, and we can conclude that the theoretical focus has mainly been based on fairly old frameworks. However, during the past decade there have been various attempts to introduce 'entrepreneurial concepts and theories', for example, as represented by the works of Aldrich (1999), Bhidé (2000) and Sarasvathy (2001), which now feature among the core works in entrepreneurship research.

\section{KNOWLEDGE USERS IN ENTREPRENEURSHIP RESEARCH}

In this section we change perspective and move from the knowledge producers and scholars who have produced the core contributions in entrepreneurship, to the users of this knowledge. We therefore employed the Web of Science 'Cited Reference Search' to locate all documents citing the 135 core works identified from the handbook chapter analysis. In total, we identified 54,469 documents in the Web of Science database citing the core entrepreneurship knowledge base, which we downloaded and analysed using Bibexcel software (Persson et al., 
2009). Following the research question formulated in the Introduction section, we focused our analysis on the geographical location of the knowledge users as well as where they published their results and the subject areas of the journals in which they publish.

\section{The geographic location of the users of core contributions}

To investigate the impact of the core contributions on a geographical level, the address field of the articles by the knowledge users was analysed. Searches were performed for each of the top 20 core works using the Web of Science 'Cited reference search' option, and documents citing these top 20 texts were retrieved and analysed, using the Web of Science 'Analyze results' function. To investigate the extent to which the impact of the core contributions was local or global, the national origin of each of the top 20 core contributions was determined, after which we investigated whether the citing documents had author addresses in the US, Europe or other continents.

The identification of the origin of the core contributions involved some problems. Among the top 20 documents are two texts by Schumpeter (1934 and 1942): one originally published in German when he resided in Austria and one published in English after he moved to the US. The main strategy for resolving this issue was to focus on the origin of the text rather than the author. Therefore, the 1934 Schumpeter text was classified as a European text while the later one was classified as American. Another problem was the 1959 contribution by Penrose, originally an American but predominantly considered a European scholar, at the same time as her contribution to the top 20 core works was written while she was still resident in America but published after her move to the UK. In this case, we chose the geographic location with which Penrose is primarily associated. The analyses were performed on one core document at a time, and the percentage of the distribution of the users was calculated as the average of the individual distributions (Table 7).

Insert Table 7 about here

Among the top 20 core contributions, four are of European origin whereas 16 originated in the US, making the total number of citations to American texts substantially higher. However, 
when looking at the average number of citations per paper, the frequencies are quite similar, with roughly 1,500 citations per paper for European core documents and 1,200 for the American ones. The overall conclusion is that core texts of American origin are equally used in the US and Europe with a $40 \%$ share of users respectively, while the other $20 \%$ have their affiliation in the rest of the world. Core contributions from Europe are to a larger extent used by European scholars, who constitute $50 \%$ of the users, while the share of American users is $30 \%$. Thus, the impact of American core contributions is more international than that of their European counterparts, who seem to have more of a local impact. There are some caveats to be considered when interpreting these results. The number of European core contributions is significantly smaller than contributions from the US. Looking at the dataset as a whole, the distribution of users is almost identical to the share of users of the American contributions. There is also one extreme outlier in the European dataset, with one text (Storey, 1994) having $79 \%$ of European users but only 7\% with an American affiliation. However, there is only one European contribution where the distribution of American and European users is fairly even and when using the median value to adjust for outliers, the distribution is still 50/32 in favour of European users of European core contributions.

\section{Thematic focus of the users of core contributions}

In this section we will conduct an analysis of the journals in which entrepreneurship knowledge base users are publishing research, and cluster them into fields based on the 'subject areas' of the journals.

\section{Journals publishing knowledge base users' research}

The 135 core works are cited in 54,469 documents in a total of 3,903 journals. The distribution of articles between journals is skewed, with a few journals accounting for a majority of the articles, whereas the rest are distributed over a large number of journals. In Table 8 we list the 20 journals with the highest number of articles citing the core texts, accounting for $18.49 \%$ of all citations to the core works. As shown in the table, the largest number of citations of the core works in entrepreneurship came from The Strategic Management Journal, Research Policy, Academy of Management Journal, Small Business Economics, Academy of Management Review, Journal of Business Venturing and Journal of Management Studies. The majority of journals can be regarded as mainstream such as The Academy of Management Journal, Academy of Management Review and Administrative 
Science Quarterly. Looking at the subject areas of the top 20 journals, we can conclude that 'business' and 'management' heavily dominate as the top citing journals in entrepreneurship research. Out of the top 20 journals, with the exception of Regional Studies, Journal of Economic Behavior and Organization, American Economic Review and Journal of Economic Issues, all include the subject area(s) 'business' and/or 'management', which indicates that scholars working in management studies are important users of entrepreneurship knowledge. Among the top 20 journals there are only two that can be regarded as entrepreneurship journals: Small Business Economics and Journal of Business Venturing.

Insert Table 8 about here

We argued above that entrepreneurship is a changeable field of research, and Table 9 illustrates that certain changes have occurred with regard to the relative importance of various journals over time. However, the relationship between the fields of strategic management and entrepreneurship is obvious, as the Strategic Management Journal is top-ranked during all three decades. Research Policy, a journal that covers broader issues with regard to technology and its effects on society, has climbed in rank. The same holds for journals such as the Journal of Management Studies and Regional Studies and, not least, entrepreneurship specific journals; Small Business Economics and Journal of Business Venturing. In the 1980s' ranking there were several journals in mainstream disciplines such as economics, sociology, political science, finance and business that have disappeared from or declined in the rankings from the 1990 s onwards. On the other hand, several journals in the top 20 rankings in the 2000s such as the International Journal of Technology Management, Technovation, Journal of Business Ethics and Organization Science have emerged.

Insert Table 9 about here

\section{Subject areas of journals publishing research by the knowledge users}

The analysis of the Web of Science 'subject areas' should be interpreted with some caution, especially in terms of seeing them as a reflection of research areas and/or as a way of looking 
at the migration of ideas between research areas. One aspect to bear in mind is that the subject areas were developed to categorise journals for information retrieval purposes, not as a way of categorizing or making distinctions between research fields. The categorization is rather static, both in terms of the categories per se and how they are used for describing the individual journals. This is a problem, not least when analysing emerging fields.

Of the total of 54,469 documents that cite the core works in entrepreneurship research (Table 10), as many as 19,072 were included in journals that can be classified as 'management', 'business' and/or 'business and finance', followed by 10,776 in journals classified as 'economics'. However, the size of the subject areas differs, for example, 'economics', 'environmental studies' and 'political science' are fairly large subject areas including a great number of articles in the Web of Science database, which means that after taking the size of the subject areas into consideration, the core entrepreneurship contributions are cited in a comparatively higher percentage of works in 'management' and 'business' compared to areas such as 'economics'. Core entrepreneurship works are cited in a large variety of different subject areas, including some not immediately related to research fields adjacent to entrepreneurship, such as computer science, education, public administration and history.

Insert Table 10 about here

The distribution of documents between subject areas has been relatively stable over time (Table 11). Very few subject areas occur in only one period and, when comparing the rankings over time, most subject areas are within the same segment. For example, the subject areas in the top segment (the top 6 subject areas) appear to maintain their position over time. However, having said that, we find that 'business', 'management' and/or 'business and finance' have strengthened their positions, whereas several subject areas in the social sciences such as sociology, political science, psychology and history have tended to become less important. Interestingly, subject areas related to engineering, including 'engineering', 'engineering, industrial' and 'computer science' have strengthened their positions over time, and to some extent the same holds true for geography (including 'planning and development'). 
Insert Table 11 about here

The classification of a journal into more than one subject area makes it possible to look at cooccurrences of subject areas to investigate the relations between them. To do this, we followed the same approach as in the previous co-citation and co-authorship analyses to produce a map of co-occurrence strengths between subject areas over time (see Figures 3a-c).

Insert Figures $3 \mathrm{a} / \mathrm{b} / \mathrm{c}$

As one would expect, the maps are centred around 'business', 'management' and 'economics'. These groupings became larger over time, i.e. the field seems to increasingly centre around 'business', 'management' and 'economics'. However, there were other changes over time. In the map of subject areas of journal articles published in the 1980s (Figure 3a) we find three distinct clusters: one (yellow circles) with 'economics' and 'business' as the strong nodes and with 'management' somewhat separated from the core; another (green circles) that can be considered a behavioural science cluster with 'sociology' as the strongest node, but including 'psychology', 'anthropology' and 'education'; and finally, a small, distinct cluster (red circles) rather far removed from the centre including natural sciences and medicine.

During the 1990s (Figure 3b) the field became more fragmented with many more subject areas, but 'business', 'management' and 'economics' (yellow circles) became even more dominant. It is interesting to note that, during this decade, the behavioural cluster became a joint cluster, bringing 'sociology', 'psychology' etc. closer to the 'economics' and 'management' clusters, while at the same time we can see that 'management' and 'business' have moved closer together whereas 'economics' has distanced itself from 'management' and 'business'. In a parallel development, a small cluster (green circles) comprising 'geography' and 'environmental studies' was formed, having broken out of the 1980s cluster. There are also two very small clusters related to health care and medicine (red and blue circles). 
The trend towards coalescence around 'management' and 'business' (yellow circles), together with 'economics' and the other social sciences continued in the 2000s. At the same time, the 'geography cluster' (green circles) has become stronger and closer to the centre (Figure 3c). We can also see a growing health care cluster (red circles), now including 'psychology'.

\section{Some concluding remarks}

In this section we explored where the users of the core entrepreneurship research works presented their results, and the most significant conclusion to be drawn is the very strong anchoring of entrepreneurship research in the 'management' and 'economics' fields as evidenced not only by the journals in which the core works were published but also by the analysis of the 'subject areas' of publications citing the core works. This to some extent contradicts the conclusions drawn by Davidsson and Wiklund (2001) that entrepreneurship research is dominated by micro-level analysis, mainly using the firm or individual as the level of analysis. 'Management' and 'economics' seemed to strengthen their positions over time and are now at the centre of entrepreneurship research. Having said that, these signs of convergence between 'management' and 'economics' should not be exaggerated as they are clearly separate field of research, we are talking about rather low level linkages between the fields, and the change over time is also quite limited (in line with the 'bounded multidisciplinarity’ in entrepreneurship research as discussed by Landström and Persson [2010]). In addition, it is obvious that the core contributions in entrepreneurship research are cited in studies within many different fields - there are a large number of low frequency users of core entrepreneurship works within a range of research fields - creating a 'long tail', suggesting that a large number of knowledge users are to be found some distance from the core of entrepreneurship research.

\section{CONCLUDING REFLECTIONS}

\section{What constitutes a core work in entrepreneurship research?}

In this study we focused on the core contributions of entrepreneurship research, the most influential scholars within the field as well as on the most highly cited works. Against this background it is worth reflecting on the question: 'What constitutes a core work in entrepreneurship research?' Davis (1971) argued that scholars are regarded as 'great' not because their theory is true, but because it is interesting. Such theories challenge the taken- 
for-granted assumptions of their audience. A large number of the core works in entrepreneurship could be regarded as interesting in the sense that the theories challenge conventional wisdom in explaining entrepreneurship as a phenomenon. The most obvious work in this respect is Birch's report The Job Generation Process (1979), in which he argued that it is young and small ventures that create the most new jobs, not large and established companies. Other examples are Acs and Audretsch's observation, contrary to conventional wisdom at the time, that small firms play an important role in innovation and industrial changes, and the study by Bhidé, which challenged conventional wisdom of venture creation and growth. Among the core works we also find interesting arguments, an example of which is Gartner who, at the end of the 1980s, challenged the existing research tradition by arguing that 'Who is the entrepreneur? is the wrong question' and instead called for a more behaviourand process-oriented approach. Thus, many core contributions can be regarded as 'interesting' in that they challenge our taken-for-granted assumptions.

In the early stages of knowledge development within a research field, it is important to gain robust empirical knowledge about the phenomenon - empirical knowledge that provides researchers with a deeper understanding and that constitutes a necessary first step in effective theory building (Eisenhardt, 1989). Thus, some of the core works in entrepreneurship research contribute by providing robust empirical knowledge, i.e. well-developed syntheses of our knowledge and/or conducting high-quality empirical studies. Among entrepreneurship scholars there has been an ambition to empirically understand the phenomenon and, naturally, among the core works in entrepreneurship we find several high-quality empirical studies. One such example is Storey's book Understanding the Small Business Sector (1994), in which the author synthesized the empirical results of a large research programme on small businesses in the UK.

\section{Entrepreneurship as an entrepreneurial achievement}

We have regarded the establishment of entrepreneurship research as an entrepreneurial achievement in itself and focused our attention on individual scholars who have made significant cognitive contributions to the field, i.e. those scholars who have formulated interesting research questions and attracted other researchers to build on their works, thus

shaping the field. Our analysis reveals that in new and evolving fields of research, as in many other emerging entrepreneurial activities, there is always a risk of becoming too 'opportunity 
oriented' (Wiklund, 1998). This means that researchers identify new research topics all the time, creating a highly fragmented field that is generally unrelated to previous knowledge, whereby the resulting lack of historical awareness creates difficulties with regard to knowledge accumulation. However, as in successful entrepreneurial ventures in general that combine an opportunity focus and resource orientation (ibid.), it is not sufficient to identify new research opportunities unless they are securely anchored to earlier knowledge within the field - what we could call a 'knowledge-based' focus combining an interest in searching for new opportunities with a stronger knowledge base within the field. This will not only help to identify new research opportunities, but also ensure a stronger accumulation of knowledge of entrepreneurship research.

\section{Future directions of entrepreneurship research}

What are the implications of our study for the future development of entrepreneurship as a research field? In line with our argumentation above, a stronger 'knowledge-based' focus can initially be achieved by borrowing concepts and theories from other fields. Historically in entrepreneurship research, this has mainly involved the fields of economics and management studies. In borrowing theories and concepts from other fields of research, it is important to understand the foundations and assumptions on which these theories are based, as otherwise mistakes may be made in any explanation or understanding of entrepreneurship as a phenomenon (Lohrke and Landström, 2010). However, our study demonstrates that, over time, the number of influential 'insider' works has increased, and the clusters of research in entrepreneurship have come closer to each other. This indicates that the field is on the way to creating a knowledge-base of its own, with distinct research specialities and a set of core knowledge. Over recent years we have seen several attempts in this direction, for example, with the emergence of concepts such as 'effectuation' (Sarasvathy, 2001), evolutionary approaches (Aldrich, 1999) and ‘bootstrapping' (Bhidé, 2000).

Despite the fact that entrepreneurship has borrowed theories from other fields and many scholars from other disciplines have migrated into entrepreneurship research, it has been surprisingly disconnected from the neighbouring field of innovation studies. Despite common roots in Schumpeter and some interrelated topics such as innovation management (corporate entrepreneurship) and an interest in technology-based firms, 'entrepreneurship' and 'innovation' have evolved over time as two separate research fields. This holds true when 
seen in a cognitive sense, focusing on the knowledge development within the fields (e.g. Bhupatiraju, Normaler, Triulzi and Verspagen in this issue; Persson, 2010) as well as in a social sense when viewing the research communities within each field (e.g. Gartner, Davidsson and Zahra, 2006). Lindholm-Dahlstrand and Stevenson (2007) also argued that innovation policy and entrepreneurship policy are rarely integrated in policy interventions by government.

Not all new ventures can be regarded as innovative and not all new knowledge generates viable (business) opportunities. However, there are several obvious connections between entrepreneurship and innovation; both are strongly linked to economic growth and industrial renewal, the concepts of 'entrepreneurship' and 'innovation' are partly intertwined (not least in everyday speech) and academic teaching often combines knowledge on entrepreneurship and innovation. In order to better understand economic growth in society, Braunerhjelm, Acs, Audretsch and Carlsson (2009) proposed a stronger emphasis on entrepreneurship in the innovation process, arguing that entrepreneurial activity is the key factor in transferring knowledge to exploit commercial opportunities. This study would seem to confirm that there is considerable potential for a stronger integration between the fields of entrepreneurship and innovation in future research.

\section{Acknowledgements}

This article is part of the EXPLORE project within the DIME Network of Excellence financed by the European Commission, and the financial support from DIME (European Commission) is gratefully acknowledged. We are indebted to workshops at CIRCLE, Lund University, TIK, Oslo University, and the School of Economics at Utrecht University, as well as the EXPLORE Conference at Lund University in December 2010 and the DIME Final Conference in Mastricht in April 2011 for valuable comments. We would especially like to thank Professor Howard Aldrich, University of North Carolina, Professor Ben Martin at SPRU, Associate Professor Jonas Gabrielsson at CIRCLE and the three reviewers of the special issue of Research Policy for valuable comments and suggestions.

\section{REFERENCES}

Acs, Z.J. and D.B. Audretsch (1990), Innovation and Small Firms, Cambridge, MA: MIT University Press.

Acs, Z.J. and D.B. Audretsch (eds.) (2003), Handbook of Entrepreneurship Research, Dordrecht: Kluwer Academic Publishers. 
Aldrich, H.E. (1979), Organizations and environments, Englewood Cliffs, NJ: Prentice Hall.

Aldrich, H.E. (1999), Organizations evolving, Thousand Oaks: SAGE.

Aldrich, H. and C. Zimmer (1986), 'Entrepreneurship Through Social Networks', in D.L. Sexton and R.W. Smilor (eds.), The Art and Science of Entrepreneurship, Cambridge, MA: Ballinger, pp. 3-23.

Alvarez, S.A., R. Agarwal and O. Sorenson (eds.) (2005), Handbook of Entrepreneurship Research: Disciplinary Perspectives, New York: Springer.

Åström, F. (2011), 'Comparing citation patterns in entrepreneurship research articles in subject handbooks and Web of Science journals', in E. Noyons, P. Ngulube and J. Leta (eds.), Proceedings of ISSI 2011: The $13^{\text {th }}$ Conference of the International Society for Scientometrics and Informatics, Leiden and KwaDlangezwa: ISSI, Leiden University and University of Zululand, pp. 89-96.

Åström, F. and Á. Sándor (2009), 'Models of Scholarly Communication and Citation Analysis', in B. Larsen and J. Leta (eds.), Proceedings of ISSI 2009: The $12^{\text {th }}$ Conference of the International Society for Scientometrics and Informatics, Rio de Janeiro: BIREME/PAHO/WHO and Federal University of Rio de Janeiro, pp. 10-21.

Audretsch, D.B. (1995), Innovation and Industry Evolution, Cambridge, MA: MIT University Press.

Audretsch, D.B. and M.P. Feldman (1996), 'R\&D spillovers and the geography of innovation and production', American Economic Review, 86(3), 630-40.

Barney, J.B. (1991), 'Firm resources and sustained competitive advantage', Journal of Management, 17, 99-120.

Baumol, W.J. (1968), 'Entrepreneurship in Economic Theory', American Economic Review, 58(2), 64-71.

Baumol, W.J. (1990), 'Entrepreneurship: Productive, Unproductive and Destructive', Journal of Political Economy, 98(5), 893-921.

Bhidé, A. (2000), The Origin and Evolution of New Businesses, New York: Oxford University Press.

Birch, D.L. (1979), The Job Generation Process, MIT Program on Neighborhood and Regional Change, Cambridge, MA.

Berger, A.N. and G.F. Udell (1998), 'The Economics of Small Business Finance', Journal of Banking and Finance, 22, 613-73.

Blanchflower, D.G. and A.J. Oswald (1998), 'What makes and entrepreneur?', Journal of Labor Economics, 16(1), 26-60. 
Bozeman, B., J. Dietz and M. Gaughan (2001), 'Scientific and technical human capital: an alternative model for research evaluation', Journal of Technology Management, 22(7/8), 71640 .

Braunerhjelm, P., Z.J. Acs, D.B. Audretsch and B. Carlsson (2009), 'The missing link: knowledge diffusion and entrepreneurship in endogenous growth', Small Business Economics, 34(2), 105-25.

Campbell, D. (1965), 'Variation and selective retention in socio-cultural evolution', in H.R. Barringer, G.I. Blanksten and R.W. Mack (eds.), Social change in developing areas, Cambridge, MA: Schenkman, pp. 19-49.

Cañibano, C. and B. Bozeman (2009), 'Curriculum vitae method in science policy and research evaluation: the state-of-the-art', Research Evaluation, 18(2), 86-94.

Cantillon, R. (1755/1999), Essai sur la nature du commerce en général, London: MacMillan.

Carroll, G.R and M. Hannan (2000), The Demography of Corporations and Industries, Princeton, NJ: Princeton University Press.

Casson, M. (1982), The entrepreneur. An economic theory, Oxford: Martin Robertson.

Casson, M., B. Yeung, A. Basu and N. Wadeson (eds.) (2006), Oxford Handbook of Entrepreneurship, Oxford: Oxford University Press.

Cohen, W.M. and D.A. Levinthal (1990), 'Absorptive capacity: a new perspective on learning and innovation', Administrative Science Quarterly, 35(1), 128-52.

Cornelius, B., H. Landström and O. Persson (2006), 'Entrepreneurial studies: the dynamic research front of a developing social science', Entrepreneurship Theory and Practice, May, 375-98.

Cyert, R.M. and J.G. March (1963), A Behavioural Theory of the Firm, Englewood Cliffs, NJ: Prentice Hall.

Crane, D. (1972), Invisible colleges. Diffusion of knowledge in scientific communities, Chicago: University of Chicago Press.

Crump, M.E.S., A. Abbery and X. Zu (2009), 'Rankings of top entrepreneurship researchers and affiliations: 1995 through 2006', paper at the 2009 Academy of Management Meeting, Chicago, 9-11 August.

Davidsson, P. (2005), Researching entrepreneurship, New York: Springer.

Davidsson, P. and J. Wiklund (2001), 'Levels of analysis in entrepreneurship research: current research practice and suggestions for the future', Entrepreneurship Theory and Practice, 24(4), 81-99.

Davis, M.S. (1971), 'That is Interesting! Towards a Phenomenology of Sociology and a Sociology of Phenomenology', Philosophy of the Social Sciences, 1, 309-44. 
De Noov, W., A. Mrvar and V. Batageli (2005), Exploratory social network analysis with Pajek, New York: Cambridge University Press.

Dietz, J.S., I. Chompalov, B. Bozeman, E. O’Neil Lane and J. Park (2000), 'Using the curriculum vita to study the career path of scientists and engineers: An exploratory assessment', Scientometrics, 49(3), 419-42.

Eisenhardt, K. (1989), 'Building theories from case study research', Academy of Management Review, 14, 532-50.

Fagerberg, J. (2002), A Layman's Guide to Evolutionary Economics, Working Paper, Oslo: TIK.

Finkle, T.A. and D. Deeds (2001), 'Trends in the market for entrepreneurship faculty', Journal of Business Venturing, 16, 613-30.

Fleck, L. (1979), The Genesis and Development of a Scientific Fact, Chicago: University of Chicago Press.

Garfield, E. (1972), 'Citation analysis as a tool in journal evaluation', Science, 178, 471-79.

Gartner, W.B. (1988), 'Who is the entrepreneur? Is the wrong question', American Journal of Small Business, 12, 11-32.

Gartner, W.B. (1990), 'What are we talking about when we talk about entrepreneurship?', Journal of Business Venturing, 5(1), 15-28.

Gartner, W.B. (1993), 'Words lead to deeds: Towards an organizational emergence vocabulary', Journal of Business Venturing, 8, 231-39.

Gartner, W.B., P. Davidsson and S.A. Zahra (2006), 'Are you talking to me? The nature of community in entrepreneurship scholarship', Entrepreneurship Theory and Practice, May, $321-31$.

Gerschenkron, A. (1947), 'The Soviet Indices of Industrial Production', Review of Economics and Statistics, 29, 217-26.

Glaeser, E.L., H.D. Kallal, J.A. Scheinkman and A. Shleifer (1992), 'Growth in Cities', Journal of Political Economy, 100(6), 1126-52.

Gompers, P. and J. Lerner (1999), The Venture Capital Cycle, Cambridge, MA: MIT Press.

Grégoire, D.A., M.X. Noël, R. Déry and J-P. Béchard (2006), 'Is there conceptual convergence in entrepreneurship research? A co-citation analysis of Frontiers of Entrepreneurship Research, 1981-2004', Entrepreneurship Theory and Practice, May, 333 73.

Hamilton, B. (2000), 'Does Entrepreneurship Pay? An Empirical Analysis of the Returns of Self-Employment', Journal of Political Economy, 108(3), 604-31. 
Hébert, R.F. and A.N. Link (1982), The Entrepreneur, New York: Praeger.

Hébert, R.F. and A.N. Link (2009), A History of Entrepreneurship, Milton Park: Routledge.

Hitt, M.A., R.D. Ireland, D.G. Sirmon and C.A. Trahms (2011), 'Strategic Entrepreneurship: Creating Value for Individuals, Organizations, and Society', Academy of Management Perspectives, 25(2), 57-75.

Hjorth, D., C. Jones and W.B. Gartner (2008), 'Introduction for recreating/recontextualising entrepreneurship', Scandinavian Journal of Management, 24, 81-84.

Jaffe, A.B., M. Trajtenberg and R. Henderson (1993), 'Geographic localization of knowledge spillovers as evidenced by patent citations', Quarterly Journal of Economics, 108(3), 577-98.

Kamada, T. and S. Kawai (1989), 'An algorithm for drawing general undirected graphs', Information Processing Letters, 31(12), 7-15.

Katz, J. (2003), 'The chronology and intellectual trajectory of American entrepreneurship education 1876-1999', Journal of Business Venturing, 18, 293-300.

Katz, J. and R. Brockhaus (eds.) (1993), Advances in entrepreneurship, firm emergence, and growth, Volume 1, Greenwich, CT: JAI Press.

Katz, J. and R. Brockhaus (eds.) (1995), Advances in entrepreneurship, firm emergence, and growth, Volume 2, Greenwich, CT: JAI Press.

Katz, J. and R. Brockhaus (eds.) (1997), Advances in entrepreneurship, firm emergence, and growth, Volume 3, Greenwich, CT: JAI Press.

Kent, C.A., D.L. Sexton and K.H. Vesper (eds.) (1982), Encyclopedia of Entrepreneurship, Englewood Cliffs, NJ: Prentice Hall,

Kihlstrom, R.E. and J.J. Laffont (1979), 'A general equilibrium entrepreneurial theory of firm formation based on risk', Journal of Political Economy, 87, 719-49.

Kirzner, I.M. (1973), Competition and Entrepreneurship, Chicago: University of Chicago Press.

Kirzner, I.M. (1997), 'Entrepreneurial discovery and the competitive market process. An Austrian approach', Journal of Economic Literature, 35(1), 60-85.

Knight, F.H. (1916/1921), Risk, Uncertainty and Profit, New York: Houghton Mifflin.

Knorr Cetina, K. (1999), Epistemic Cultures: How the Sciences Make Knowledge, Cambridge, MA: Harvard Business School Press.

Krugman, P. (1991), Geography and Trade, Cambridge, MA: MIT Press. 
Kuhn, T. (1970), The structure of scientific revolutions, Chicago: University of Chicago Press.

Landes, D. (1949), 'French Entrepreneurship and Industrial Growth in the Nineteenth Century', Journal of Economic History, 9, 45-61.

Landström, H. (2005), Pioneers in entrepreneurship and small business research, New York: Springer.

Landström, H. and M. Benner (2010), 'Entrepreneurship research: a history of scholarly migration', in H. Landström and F. Lohrke (eds.), Historical Foundations of Entrepreneurship Research, Cheltenham: Edward Elgar, pp. 15-45.

Landström, H. and O. Persson (2010), 'Entrepreneurship research: research communities and knowledge platforms', in H. Landström and F. Lohrke (eds.), Historical Foundations of Entrepreneurship Research, Cheltenham: Edward Elgar, pp. 46-76.

Lindholm-Dahlstrand, Å. and L. Stevenson (2007), Linking Innovation and Entrepreneurship Policy, Working Paper, Stockholm: IPREG.

Lohrke, F. and H. Landström (2010), 'History matters in entrepreneurship research', in H. Landström and F. Lohrke (eds.), Historical Foundations of Entrepreneurship Research, Cheltenham: Edward Elgar, pp. 1-11.

Low, M.B. (2001), 'The adolescence of entrepreneurship research: specification of purpose', Entrepreneurship Theory and Practice, 24(4), 17-39.

Lucas, R.E. (1978), 'On the size distribution of business firms', Bell Journal of Economics, 9, $508-23$.

McClelland, D.C. (1961), The Achieving Society, Princeton, NJ: van Nostrand.

Merton, R.K. (1973), The Sociology of Science, Chicago: University of Chicago Press.

Nagy, B. and F. Lohrke (2010), 'Only the good die young? A review of liability of newness and related new venture mortality research', in H. Landström and F. Lohrke (eds.), Historical Foundations in Entrepreneurship Research, Cheltenham: Edward Elgar, pp. 185-204.

Nelson, R. and S. Winter (1982), An Evolutionary Theory of Economic Change, Cambridge, MA: Harvard University Press.

Parker, S.C. (2005), 'The economics of entrepreneurship: what we know and what we don't', Foundations and Trends in Entrepreneurship, 1(1), 1-54.

Parker, S.C. (ed.) (2006), The Life Cycle of Entrepreneurial Ventures, New York: Springer.

Penrose, E.T. (1959), The theory of the growth of the firm, Oxford: Blackwell.

Persson, O. (1994), 'The intellectual base and research fronts of JASIS 1986-1990', Journal of the American Society for Information Science, 45(1), 31-38. 
Persson, O. (2010), Networks of paper in entrepreneurship, innovation, and science \& technology studies, paper presented at the EXPLORE Workshop, CIRCLE, Lund University, 7-8 December.

Persson, O., R. Danell and J.W. Schneider (2009), 'How to use Bibexcel for various types of bibliometric analysis', in F. Åström et al. (eds.), Celebrating Scholarly Communication Studies: A Festschrift for Olle Persson at his $60^{\text {th }}$ Birthday, ISSI, pp. 9-24.

http://www.issi-society.info/ollepersson60/ (2010.11.15)

Porter, M. (1990), The Competitive Advantage of Nations, New York: Free Press.

Sahlman, W. (1990), 'The structure and governance of venture capital organizations', Journal of Financial Economics, 27, 473-521.

Sarasvathy, S. (2001), 'Causation and effectuation: toward a theoretical shift from economic inevitability to entrepreneurial contingency', Academy of Management Review, 26(2), 243-63.

Saxenian, A.L. (1994), Regional advantage: Culture and competition in Silicon Valley and Route 128, Cambridge, MA: Harvard University Press.

Schumpeter, J.A. (1912), Theorie der Wirtschaftlichen Entwicklung, Leipzig: Dunker \& Humblot.

Schumpeter, J.A. (1934), The Theory of Economic Development, Cambridge, MA: Harvard University Press.

Schumpeter, J.A. (1942), Capitalism, Socialism and Democracy, New York: Harper \& Row.

Sexton, D.L. and J.D. Kasarda (eds.) (1992), The State of the Art of Entrepreneurship, Boston, MA: PWS-Kent Publishers.

Sexton, D.L. and H. Landström (eds.) (2000), The Blackwell Handbook of Entrepreneurship, Oxford: Blackwell.

Sexton, D.L. and R.W. Smilor (eds.) (1986), The Art and Science of Entrepreneurship, Cambridge, MA: Ballinger.

Sexton, D.L. and R.W. Smilor (eds.) (1997), Entrepreneurship 2000, Chicago, IL: Upstart.

Shane, S.A. (1997), 'Who is publishing in entrepreneurship research', Journal of Management, 23, 83-95.

Shane, S.A. (2000), 'Prior knowledge and the discovery of entrepreneurial opportunities', Organization Science, 11(4), 448-69.

Shane, S.A. and S. Venkataraman (2000), 'The promise of entrepreneurship as a field of research', Academy of Management Review, 25(1), 217-26. 
Simon, H.A. (1959), 'Theories of decision making in economics', American Economic Review, 49, 253-83.

Simon, H.A. (1965), Administrative Behaviour, New York: Free Press.

Smith, A. (1776), An Inquiry into the Nature and Causes of the Wealth of Nations, London: Methuen and Co.

Sorenson, O. and T.E. Stuart (2001), 'Syndication networks and the spatial distribution of venture capital investments', American Journal of Sociology, 106(6), 1546-88.

Stinchcombe, A.L. (1965), 'Organizations and social structure', in J.G. March (ed.), Handbook of Organizations, Chicago: Rand McNally \& Company, pp. 142-93.

Storey, D.J. (1994), Understanding the Small Business Sector, London: Routledge.

Swedberg, R. (2000), Entrepreneurship. The Social Science View, Oxford: Oxford University Press.

Teece, D.J., G. Pisano and A. Sheen (1997), 'Dynamic capabilities and strategic management', Strategic Management Journal, 18(7), 509-33.

Van Praag, C.M. (2005), Successful Entrepreneurship. Confronting Economic Theory with Empirical Practice, Cheltenham: Edward Elgar.

Venkataraman, S. (1997), 'The distinctive domain of entrepreneurship research', in J.A. Katz (ed.), Advances in entrepreneurship, firm emergence and growth, Vol. 3, Oxford:

Elsevier/JAI Press, pp. 119-38.

Watkins, D. (2005), Identifying Trends in Entrepreneurship Research: Textual Analysis Revisited, paper presented at the Academy of Management Meeting, Honolulu, Hawaii, August 5-10.

White, H.D. and B.C. Griffith (1981), 'Author co-citation: A literature measure of intellectual structure’, Journal of the American Society for Information Science, 32, 463-72.

Wiklund, J. (1998), Small Firm Growth and Performance: Entrepreneurship and Beyond, Jönköping: Jönköping International Business School.

Zahra, S.A. (2005), 'Entrepreneurship and Disciplinary Scholarship: Return to the Fountainhead', in S.A. Alvarez, R. Agarwal and O. Sorenson (eds.), Handbook of Entrepreneurship Research. Interdisciplinary Perspectives, New York: Springer, pp 253-68. 
Table 1 List of 'Handbooks'

\begin{tabular}{|c|c|c|c|c|c|}
\hline Editors & Title & Year & Publisher & Chapters* & References \\
\hline $\begin{array}{l}\text { Kent, C.A., } \\
\text { Sexton, D.L. and } \\
\text { Vesper, K.H. }\end{array}$ & Encyclopedia of Entrepreneurship & 1982 & Prentice-Hall & 18 & 630 \\
\hline $\begin{array}{l}\text { Sexton, D.L. and } \\
\text { Smilor, R.W. }\end{array}$ & $\begin{array}{l}\text { The Art and Science of } \\
\text { Entrepreneurship }\end{array}$ & 1986 & Ballinger & 11 & 381 \\
\hline $\begin{array}{l}\text { Sexton, D.L. and } \\
\text { Kasarda, J.D. }\end{array}$ & $\begin{array}{l}\text { The State of the Art of } \\
\text { Entrepreneurship }\end{array}$ & 1992 & PWS-KENT & 22 & 1547 \\
\hline $\begin{array}{l}\text { Katz, J.A. and } \\
\text { Brockhaus, R.H. }\end{array}$ & $\begin{array}{l}\text { Advances in Entrepreneurship, } \\
\text { Firm Emergence, and Growth, } \\
\text { Vol. } 1\end{array}$ & 1993 & JAI Press & 5 & 335 \\
\hline $\begin{array}{l}\text { Katz, J.A. and } \\
\text { Brockhaus, R.H. }\end{array}$ & $\begin{array}{l}\text { Advances in Entrepreneurship, } \\
\text { Firm Emergence, and Growth, } \\
\text { Vol. } 2\end{array}$ & 1995 & JAI Press & 8 & 657 \\
\hline $\begin{array}{l}\text { Katz, J.A. and } \\
\text { Brockhaus, R.H. }\end{array}$ & $\begin{array}{l}\text { Advances in Entrepreneurship, } \\
\text { Firm Emergence, and Growth, } \\
\text { Vol. } 3\end{array}$ & 1997 & JAI Press & 7 & 852 \\
\hline $\begin{array}{l}\text { Sexton, D.L. and } \\
\text { Smilor, R.W. }\end{array}$ & Entrepreneurship 2000 & 1997 & Upstart & 18 & 907 \\
\hline $\begin{array}{l}\text { Sexton, D.L. and } \\
\text { Landström, H. }\end{array}$ & $\begin{array}{l}\text { The Blackwell Handbook of } \\
\text { Entrepreneurship }\end{array}$ & 2000 & Blackwell & 22 & 1427 \\
\hline $\begin{array}{l}\text { Acs, Z.J. and } \\
\text { Audretsch, D.B. }\end{array}$ & $\begin{array}{l}\text { Handbook of Entrepreneurship } \\
\text { Research }\end{array}$ & 2003 & Kluwer & 19 & 1687 \\
\hline $\begin{array}{l}\text { Alvarez, S.A., } \\
\text { Agarwal, R. and } \\
\text { Sorenson, O. }\end{array}$ & $\begin{array}{l}\text { Handbook of Entrepreneurship } \\
\text { Research: Disciplinary } \\
\text { Perspectives }\end{array}$ & 2005 & Springer & 11 & 652 \\
\hline $\begin{array}{l}\text { Casson, M., } \\
\text { Yeung, B., } \\
\text { Basu, A. and } \\
\text { Wadeson, N. }\end{array}$ & $\begin{array}{l}\text { Oxford Handbook of } \\
\text { Entrepreneurship }\end{array}$ & 2006 & Oxford & 27 & 2079 \\
\hline Parker, S. & $\begin{array}{l}\text { The Life Cycle of Entrepreneurial } \\
\text { Ventures }\end{array}$ & 2006 & Springer & 17 & 1627 \\
\hline & & & & 185 & 12781 \\
\hline
\end{tabular}

* Total number of chapters that have references. This has also been the basis for calculating E in the J-index. 
Table 2 Top 20 scholars

\begin{tabular}{|c|c|c|c|c|c|c|c|c|}
\hline Rank & $\begin{array}{l}\text { Total } \\
\text { SSCI }\end{array}$ & $\begin{array}{l}\text { Total } \\
\text { J- } \\
\text { index }\end{array}$ & $\begin{array}{l}\text { Ratio } \\
\text { SSCI/ } \\
\text { J-index }\end{array}$ & $\begin{array}{l}\text { Ratio } \\
\text { SSCI/J- } \\
\text { index } \\
\text { per core } \\
\text { work }\end{array}$ & Author & Year(s) & Country & Affiliation(s) \\
\hline 1 & 7813 & 47.02 & 166.16 & 83.08 & $\begin{array}{l}\text { Joseph } \\
\text { Schumpeter }\end{array}$ & 1934,1942 & $\begin{array}{l}\text { Austria/ } \\
\text { USA }\end{array}$ & Harvard University \\
\hline 2 & 504 & 29.52 & 17.07 & 3.41 & William Gartner & $\begin{array}{l}1985,1988, \\
1990,1992, \\
1995\end{array}$ & USA & $\begin{array}{l}\text { University of Virginia } \\
\text { Georgetown University } \\
\text { University of Southern } \\
\text { California } \\
\text { San Francisco State University }\end{array}$ \\
\hline 3 & 2080 & 29.23 & 71.16 & 11.86 & Howard Aldrich & $\begin{array}{l}1979,1986, \\
1990,1993, \\
1994,1999\end{array}$ & USA & $\begin{array}{l}\text { Cornell University, USA } \\
\text { University of North Carolina }\end{array}$ \\
\hline 4 & 1012 & 29.30 & 34.54 & 11.51 & Israel Kirzner & $\begin{array}{l}1973,1979, \\
1997\end{array}$ & USA & New York University \\
\hline 5 & 351 & 27.71 & 12.67 & 6.34 & Scott Shane & 2000,2000 & USA & $\begin{array}{l}\text { MIT } \\
\text { University of Maryland, }\end{array}$ \\
\hline 6 & 348 & 21.91 & 15.88 & 7.94 & $\begin{array}{l}\text { Sankaran } \\
\text { Venkataraman }\end{array}$ & 1997,2000 & USA & $\begin{array}{l}\text { Rensselaer Polytechnic } \\
\text { Institute } \\
\text { University of Virginia }\end{array}$ \\
\hline 7 & 352 & 17.14 & 20.54 & 6.85 & William Baumol & $\begin{array}{l}1968,1990, \\
1993\end{array}$ & USA & New York University \\
\hline 8 & 774 & 16.59 & 46.65 & 11.66 & David Audretsch & $\begin{array}{l}1988,1990 \\
1995,1996\end{array}$ & $\begin{array}{l}\text { Germany } \\
/ \\
\text { USA }\end{array}$ & $\begin{array}{l}\text { Wissenschaftszentrum Berlin } \\
\text { fur Sozialforschung }\end{array}$ \\
\hline 9 & 1765 & 15.68 & 112.56 & 112.56 & Frank Knight & 1921 & USA & University of Chicago \\
\hline 10 & 572 & 14.62 & 39.12 & 19.56 & David Birch & 1979,1987 & USA & MIT \\
\hline 11 & 106 & 12.16 & 8.72 & 8.72 & Amarnath Bhidé & 2000 & USA & Harvard Business School \\
\hline 12 & 154 & 11.90 & 12.94 & 12.94 & $\begin{array}{l}\text { David } \\
\text { Blanchflower }\end{array}$ & $\begin{array}{l}1998,2000, \\
2001\end{array}$ & USA & Dartmouth College \\
\hline 13 & 2694 & 11.89 & 226.58 & 226.58 & David McClelland & 1961 & USA & Harvard University \\
\hline 14 & 474 & 11.63 & 40.76 & 40.76 & David Storey & 1994 & UK & Warwick Business School \\
\hline 15 & 184 & 11.38 & 16.17 & 16.17 & Mark Casson & 1982 & UK & University of Reading \\
\hline 16 & 2789 & 11.10 & 251.26 & 125.63 & Jay Barney & 1991,1997 & USA & $\begin{array}{l}\text { Texas A\&M University } \\
\text { Ohio State University }\end{array}$ \\
\hline 17 & 7663 & 10.97 & 698.54 & 349.27 & Michael Porter & 1980,1990 & USA & Harvard Business School \\
\hline 18 & 165 & 10.94 & 15.08 & 7.54 & Josh Lerner & 1999, 1999 & USA & Harvard Business School \\
\hline 19 & 327 & 10.90 & 30.00 & 10.00 & David Evans & $\begin{array}{l}1989,1989, \\
1990\end{array}$ & USA & $\begin{array}{l}\text { NERA: National Economic } \\
\text { Research Associates, Inc. }\end{array}$ \\
\hline 20 & 1236 & 10.85 & 113.92 & 113.92 & $\begin{array}{l}\text { AnnaLee } \\
\text { Saxenian }\end{array}$ & 1994 & USA & University of California \\
\hline
\end{tabular}


Table 3 Top-ranked 'entrepreneurship scholars' - CV-analysis

\begin{tabular}{|c|c|c|c|}
\hline & Number & Average & Median \\
\hline \multicolumn{4}{|l|}{ Career trajectories } \\
\hline Age - PhD-degree & 14 & 29.1 years & 29.0 years \\
\hline Age on becoming Assistant Professor & 11 & 29.1 years & 29.0 years \\
\hline Age on becoming Associate Professor & 10 & 34.1 years & 34.0 years \\
\hline Age on becoming Full Professor & 13 & 39.0 years & 39.0 years \\
\hline Age when publishing the first major work in entrepreneurship & 14 & 40.0 years & 40.0 years \\
\hline \multicolumn{4}{|l|}{ Mobility } \\
\hline Number of employment institutions (academic) & 14 & 3.3 & 3.0 \\
\hline Number of visiting professorships & 11 & 2.6 & 1.0 \\
\hline \multicolumn{4}{|l|}{ Scientific productivity } \\
\hline $\begin{array}{l}\text { Total number of publications (books, edited books, book chapters and } \\
\text { refereed journal articles) }\end{array}$ & 12 & 113.8 & 100.0 \\
\hline Number of books & 12 & 7.4 & 7.5 \\
\hline Number of edited books & 12 & 5.4 & 1.5 \\
\hline Number of book chapters & 12 & 33.1 & 21.0 \\
\hline Number of single authored refereed journal articles & 12 & 22.7 & 23.5 \\
\hline Number of multi-authored refereed journal articles & 12 & 45.2 & 46.5 \\
\hline Co-authorship ratio (single/multi-authored articles) & & 0.50 & 0.51 \\
\hline
\end{tabular}


Table 4 Core literature ratio - age distribution

\begin{tabular}{|l|l|l|c|}
\hline & $\begin{array}{l}\text { Frequency: } \\
\text { Core literature }\end{array}$ & $\begin{array}{l}\text { Frequency: Duplicates } \\
\text { (titles) }\end{array}$ & $\begin{array}{l}\text { Ratio: } \\
\text { Core literature to Duplicates }\end{array}$ \\
\hline$<1980$ & 22 & 264 & $17.1 \%$ \\
\hline $1980-1989$ & 36 & 514 & $7.0 \%$ \\
\hline $1990-1999$ & 56 & 641 & $8.7 \%$ \\
\hline $2000-2002 *$ & 21 & 111 & $18.9 \%$ \\
\hline & 135 & 1530 & \\
\hline
\end{tabular}

*69 titles published after 2002 have been removed as they are included in too few 'handbooks'. 
Table 5 Publication year of outsider and insider works in entrepreneurship research

\begin{tabular}{|l|c|c|c|c|c|}
\hline \multicolumn{7}{|c|}{ Publication year of core works } \\
\hline & $<\mathbf{1 9 8 0}$ & $\mathbf{1 9 8 0 - 1 9 8 9}$ & $\mathbf{1 9 9 0 - 1 9 9 9}$ & $\mathbf{2 0 0 0 - 2 0 0 2}$ & Total number \\
\hline Outsider & 14 & 10 & 24 & 2 & 50 \\
\hline Insider & 8 & 26 & 32 & 19 & 85 \\
\hline $\begin{array}{l}\text { Ratio: } \\
\text { Outsider/Insider }\end{array}$ & 1.75 & 0.38 & 0.75 & 0.11 & 0.59 \\
\hline
\end{tabular}


Table 6 Top 20 core works

\begin{tabular}{|c|c|c|c|c|c|c|c|}
\hline Rank & Year & Author(s) & Title & Type & J-index & $\begin{array}{l}\text { SSCI } \\
\text { Citation }\end{array}$ & $\begin{array}{l}\text { SSCI/ } \\
\text { Year }\end{array}$ \\
\hline 1 & 1934 & Schumpeter, J. & $\begin{array}{l}\text { Theory of Economic } \\
\text { Development, Cambridge, } \\
\text { MA: Harvard University Press. }\end{array}$ & Book & 33.51 & 2967 & 57.06 \\
\hline 2 & 2000 & $\begin{array}{l}\text { Shane, S. and } \\
\text { Venkataraman, } \\
\text { S. }\end{array}$ & $\begin{array}{l}\text { 'The Promise of } \\
\text { Entrepreneurship as a Field of } \\
\text { Research', } \\
\text { Academy of Management } \\
\text { Review }\end{array}$ & Article & 22.97 & 342 & 42.75 \\
\hline 3 & 2000 & Shane, S. & $\begin{array}{l}\text { 'Prior Knowledge and the } \\
\text { Discovery of Entrepreneurial } \\
\text { Opportunities', } \\
\text { Organization Science }\end{array}$ & Article & 16.22 & 180 & 22.50 \\
\hline 4 & 1921 & Knight, F. & $\begin{array}{l}\text { Risk, Uncertainty and Profit, } \\
\text { Chicago, IL: University of } \\
\text { Chicago Press. }\end{array}$ & Book & 15.68 & 1765 & 33.94 \\
\hline 5 & 1942 & Schumpeter, J. & $\begin{array}{l}\text { Capitalism, Socialism and } \\
\text { Democracy, New York: } \\
\text { Harper and Brothers. }\end{array}$ & Book & 13.51 & 4846 & 93.19 \\
\hline 6 & 1988 & Gartner, W. & $\begin{array}{l}\text { 'Who is an entrepreneur? Is } \\
\text { the wrong question', } \\
\text { American Journal of Small } \\
\text { Business }\end{array}$ & Article & 12.85 & 217 & 10.85 \\
\hline 7 & 2000 & Bhidé A. & $\begin{array}{l}\text { The Origin and Evolution of } \\
\text { New Businesses, New York: } \\
\text { Oxford University Press. }\end{array}$ & Book & 12.16 & 106 & 13.25 \\
\hline 8 & 1973 & Kirzner, I. & $\begin{array}{l}\text { Competition and } \\
\text { Entrepreneurship, Chicago, } \\
\text { IL: University of Chicago. }\end{array}$ & Book & 11.89 & 592 & 16.91 \\
\hline 9 & 1961 & McClelland, D. & $\begin{array}{l}\text { The Achieving Society, } \\
\text { Princeton, NJ: Van Nostrand. }\end{array}$ & Book & 11.89 & 2694 & 57.32 \\
\hline 10 & 1994 & Storey, D. & $\begin{array}{l}\text { Understanding the Small } \\
\text { Business Sector, London: } \\
\text { Routledge. }\end{array}$ & Book & 11.63 & 474 & 33.86 \\
\hline 11 & 1997 & Kirzner, I. & $\begin{array}{l}\text { 'Entrepreneurial Discovery } \\
\text { and the Competitive Market } \\
\text { Process: An Austrian } \\
\text { approach', Journal of } \\
\text { Economic Literature }\end{array}$ & Article & 11.46 & 172 & 15.64 \\
\hline 12 & 1982 & Casson, $\mathrm{M}$. & $\begin{array}{l}\text { The Entrepreneur: An } \\
\text { Economic Theory, Oxford: } \\
\text { Martin Robertson }\end{array}$ & Book & 11.38 & 184 & 7.08 \\
\hline 13 & 1986 & $\begin{array}{l}\text { Aldrich, H. and } \\
\text { Zimmer, C. }\end{array}$ & $\begin{array}{l}\text { 'Entrepreneurship through } \\
\text { Social Networks', in D. Sexton } \\
\text { and R. Smilor (eds.), The Art } \\
\text { and Science of } \\
\text { Entrepreneurship, New York: } \\
\text { Ballinger, pp. 3-23. }\end{array}$ & $\begin{array}{l}\text { Book } \\
\text { chapter }\end{array}$ & 10.90 & 204 & 9.27 \\
\hline 14 & 1994 & Saxenian, A. & $\begin{array}{l}\text { Regional Advantage: Culture } \\
\text { and Competition in Silicon } \\
\text { Valley and Route 128, } \\
\text { Cambridge, MA: Harvard } \\
\text { University Press. }\end{array}$ & Book & 10.85 & 1236 & 88.29 \\
\hline
\end{tabular}




\begin{tabular}{|c|c|c|c|c|c|c|c|}
\hline 15 & 1997 & $\begin{array}{l}\text { Venkataraman, } \\
\text { S. }\end{array}$ & $\begin{array}{l}\text { 'The Distinctive Domain of } \\
\text { Entrepreneurship Research', in } \\
\text { J. Katz and R. Brockhaus } \\
\text { (eds.), Advances in } \\
\text { Entrepreneurship, Firm } \\
\text { Emergence and Growth, } \\
\text { Greenwich, CT: JAI Press, pp. } \\
\text { 119-38. }\end{array}$ & $\begin{array}{l}\text { Book } \\
\text { chapter }\end{array}$ & 10.42 & 177 & 16.09 \\
\hline 16 & 1965 & Stinchcombe, A. & $\begin{array}{l}\text { 'Social Structure and } \\
\text { Organizations', in J.G. March } \\
\text { (ed.), Handbook of } \\
\text { Organizations, Chicago, ILL: } \\
\text { Rand-McNally, pp. 142-93. }\end{array}$ & $\begin{array}{l}\text { Book } \\
\text { chapter }\end{array}$ & 9.73 & 1289 & 29.98 \\
\hline 17 & 1959 & Penrose, E. & $\begin{array}{l}\text { Theory of the Growth of the } \\
\text { Firm, Oxford: Oxford } \\
\text { University Press. }\end{array}$ & Book & 9.73 & 2169 & 44.27 \\
\hline 18 & 1982 & $\begin{array}{l}\text { Nelson, R. and } \\
\text { Winter, S. }\end{array}$ & $\begin{array}{l}\text { An Evolutionary Theory of } \\
\text { Economic Change, } \\
\text { Cambridge: Harvard } \\
\text { University Press. }\end{array}$ & Book & 9.58 & 4303 & 165.50 \\
\hline 19 & 2000 & Hamilton, B. & $\begin{array}{l}\text { 'Does Entrepreneurship Pay? } \\
\text { An Empirical Analysis of the } \\
\text { Returns to Self-employment', } \\
\text { Journal of Political Economy }\end{array}$ & Article & 9.46 & 78 & 9.75 \\
\hline 20 & 1999 & Aldrich, H. & $\begin{array}{l}\text { Organizations Evolving, } \\
\text { London: Sage. }\end{array}$ & Book & 9.38 & 457 & 50.78 \\
\hline
\end{tabular}


Table 7 Geographic distribution of users citing the top 20 core contributions

\begin{tabular}{|l|c|c|c|}
\hline Core text origin & $\begin{array}{c}\text { European users: } \\
\text { Average/Median }\end{array}$ & $\begin{array}{c}\text { US users: } \\
\text { Average/Median }\end{array}$ & $\begin{array}{c}\text { Other users: } \\
\text { Average/Median }\end{array}$ \\
\hline $\begin{array}{l}\text { Total (24,948 } \\
\text { citations) }\end{array}$ & $42 \% / 42 \%$ & $40 \% / 39 \%$ & $18 \% / 18 \%$ \\
\hline $\begin{array}{l}\text { Europe }(4 \text { texts, } \\
6,123 \text { citations) }\end{array}$ & $55 \% / 50 \%$ & $27 \% / 32 \%$ & $18 \% / 18 \%$ \\
\hline $\begin{array}{l}\text { US (16 texts, } \\
18,825 \text { citations) }\end{array}$ & $39 \% / 41 \%$ & $43 \% / 40 \%$ & $18 \% / 18 \%$ \\
\hline
\end{tabular}


Table 8 Top 20 most citing journals in entrepreneurship

\begin{tabular}{|c|c|c|c|c|}
\hline Rank & Journal & Frequency & $\begin{array}{l}\text { Ratio of total } \\
\text { works }\end{array}$ & Subjects \\
\hline 1 & Strategic Management Journal & 1,278 & 2.35 & $\begin{array}{l}\text { Business; } \\
\text { Management }\end{array}$ \\
\hline 2 & Research Policy & 711 & 1.31 & $\begin{array}{l}\text { Management; } \\
\text { Planning \& } \\
\text { Development }\end{array}$ \\
\hline 3 & $\begin{array}{l}\text { Academy of Management } \\
\text { Journal }\end{array}$ & 626 & 1.15 & $\begin{array}{l}\text { Business; } \\
\text { Management }\end{array}$ \\
\hline 4 & Small Business Economics & 572 & 1.05 & $\begin{array}{l}\text { Business; Economics; } \\
\text { Management }\end{array}$ \\
\hline 5 & $\begin{array}{l}\text { Academy of Management } \\
\text { Review }\end{array}$ & 564 & 1.04 & $\begin{array}{l}\text { Business; } \\
\text { Management }\end{array}$ \\
\hline 6 & Journal of Business Venturing & 554 & 1.02 & Business \\
\hline 7 & Journal of Management Studies & 549 & 1.01 & $\begin{array}{l}\text { Business; } \\
\text { Management }\end{array}$ \\
\hline 8 & $\begin{array}{l}\text { Administrative Science } \\
\text { Quarterly }\end{array}$ & 445 & 0.82 & $\begin{array}{l}\text { Business; } \\
\text { Management }\end{array}$ \\
\hline 9 & $\begin{array}{l}\text { International Journal of } \\
\text { Technology Management }\end{array}$ & 442 & 0.81 & $\begin{array}{l}\text { Engineering; } \\
\text { Multidisciplinary; } \\
\text { Management; } \\
\text { Operations Research } \\
\text { \& Management } \\
\text { Science }\end{array}$ \\
\hline 10 & Organization Studies & 438 & 0.80 & Management \\
\hline 11 & $\begin{array}{l}\text { Journal of International } \\
\text { Business Studies }\end{array}$ & 431 & 0.79 & $\begin{array}{l}\text { Business; } \\
\text { Management }\end{array}$ \\
\hline 12 & Organization Science & 425 & 0.78 & Management \\
\hline 13 & Regional Studies & 412 & 0.76 & $\begin{array}{l}\text { Environmental } \\
\text { Studies; Geography }\end{array}$ \\
\hline 14 & Journal of Business Research & 402 & 0.74 & Business \\
\hline 15 & $\begin{array}{l}\text { Journal of Economic Behavior } \\
\text { and Organization }\end{array}$ & 399 & 0.73 & Economics \\
\hline 16 & American Economic Review & 393 & 0.72 & Economics \\
\hline 17 & Management Science & 373 & 0.68 & $\begin{array}{l}\text { Management; } \\
\text { Operations Research } \\
\text { \& Management } \\
\text { Science } \\
\end{array}$ \\
\hline 18 & Journal of Business Ethics & 367 & 0.67 & Business; Ethics \\
\hline 19 & Journal of Management & 351 & 0.64 & $\begin{array}{l}\text { Business; } \\
\text { Management }\end{array}$ \\
\hline 20 & Journal of Economic Issues & 337 & 0.62 & Economics \\
\hline
\end{tabular}

Total 54,469 documents 
Table 9 Top journals over time (1980s, 1990s and 2000s)

\begin{tabular}{|c|c|c|c|c|c|c|}
\hline Rank & $1980 \mathrm{~s}$ & Freq. & $1990 \mathrm{~s}$ & Freq. & $2000 \mathrm{~s}$ & Freq. \\
\hline 1 & $\begin{array}{l}\text { Strategic Management } \\
\text { Journal }\end{array}$ & 183 & $\begin{array}{l}\text { Strategic Management } \\
\text { Journal }\end{array}$ & 594 & $\begin{array}{l}\text { Strategic Management } \\
\text { Journal }\end{array}$ & 533 \\
\hline 2 & $\begin{array}{l}\text { Administrative Science } \\
\text { Quarterly }\end{array}$ & 132 & $\begin{array}{l}\text { Academy of } \\
\text { Management Journal }\end{array}$ & 233 & Research Policy & 455 \\
\hline 3 & $\begin{array}{l}\text { Academy of } \\
\text { Management Review }\end{array}$ & 114 & Research Policy & 221 & $\begin{array}{l}\text { Small Business } \\
\text { Economics }\end{array}$ & 368 \\
\hline 4 & $\begin{array}{l}\text { American Economic } \\
\text { Review }\end{array}$ & 104 & $\begin{array}{l}\text { Small Business } \\
\text { Economics }\end{array}$ & 218 & $\begin{array}{l}\text { International Journal of } \\
\text { Technology } \\
\text { Management }\end{array}$ & 328 \\
\hline 5 & $\begin{array}{l}\text { Journal of Economic } \\
\text { Behavior \& } \\
\text { Organisation }\end{array}$ & 96 & $\begin{array}{l}\text { Journal of Business } \\
\text { Venturing }\end{array}$ & 218 & $\begin{array}{l}\text { Academy of } \\
\text { Management Journal }\end{array}$ & 296 \\
\hline 6 & $\begin{array}{l}\text { Academy of } \\
\text { Management Journal }\end{array}$ & 85 & $\begin{array}{l}\text { Academy of } \\
\text { Management Review }\end{array}$ & 214 & $\begin{array}{l}\text { Journal of Management } \\
\text { Studies }\end{array}$ & 292 \\
\hline 7 & $\begin{array}{l}\text { Journal of Economic } \\
\text { Issues }\end{array}$ & 81 & $\begin{array}{l}\text { Journal of Management } \\
\text { Studies }\end{array}$ & 205 & $\begin{array}{l}\text { Journal of Business } \\
\text { Venturing }\end{array}$ & 284 \\
\hline 8 & Journal of Finance & 78 & $\begin{array}{l}\text { Journal of Institutional } \\
\text { and Theoretical } \\
\text { Economics }\end{array}$ & 171 & Technovation & 270 \\
\hline 9 & Long Range Planning & 78 & Organization Science & 169 & $\begin{array}{l}\text { Journal of Business } \\
\text { Ethics }\end{array}$ & 263 \\
\hline 10 & $\begin{array}{l}\text { American Journal of } \\
\text { Sociology }\end{array}$ & 74 & $\begin{array}{l}\text { Journal of Economic } \\
\text { Behavior \& } \\
\text { Organisation }\end{array}$ & 151 & Organization Science & 256 \\
\hline 11 & $\begin{array}{l}\text { History of Political } \\
\text { Economy }\end{array}$ & 73 & Organization Studies & 150 & $\begin{array}{l}\text { Journal of International } \\
\text { Business Studies }\end{array}$ & 252 \\
\hline 12 & $\begin{array}{l}\text { Managerial and } \\
\text { Decision Economics }\end{array}$ & 68 & $\begin{array}{l}\text { Administrative Science } \\
\text { Quarterly }\end{array}$ & 149 & $\begin{array}{l}\text { Journal of Business } \\
\text { Research }\end{array}$ & 251 \\
\hline 13 & Management Science & 65 & $\begin{array}{l}\text { Journal of International } \\
\text { Business Studies }\end{array}$ & 145 & Regional Studies & 250 \\
\hline 14 & Journal of Marketing & 63 & Long Range Planning & 141 & $\begin{array}{l}\text { Academy of } \\
\text { Management Review }\end{array}$ & 250 \\
\hline 15 & $\begin{array}{l}\text { American Sociological } \\
\text { Review }\end{array}$ & 62 & Journal of Management & 137 & $\begin{array}{l}\text { Industrial and } \\
\text { Corporate Change }\end{array}$ & 237 \\
\hline 16 & $\begin{array}{l}\text { Journal of Financial } \\
\text { Economics }\end{array}$ & 61 & Regional Studies & 126 & Organization Studies & 230 \\
\hline 17 & Organization Studies & 58 & $\begin{array}{l}\text { Journal of Business } \\
\text { Research } \\
\end{array}$ & 125 & $\begin{array}{l}\text { Industrial Marketing } \\
\text { Management }\end{array}$ & 204 \\
\hline 18 & $\begin{array}{l}\text { Journal of Post } \\
\text { Keyenesian Economics }\end{array}$ & 58 & $\begin{array}{l}\text { International Journal of } \\
\text { Technology } \\
\text { Management }\end{array}$ & 122 & Management Science & 190 \\
\hline 19 & $\begin{array}{l}\text { Journal of Management } \\
\text { Studies }\end{array}$ & 58 & Management Science & 114 & $\begin{array}{l}\text { European Planning } \\
\text { Studies }\end{array}$ & 189 \\
\hline 20 & $\begin{array}{l}\text { Southern Economic } \\
\text { Journal }\end{array}$ & 55 & $\begin{array}{l}\text { History of Political } \\
\text { Economy }\end{array}$ & 106 & $\begin{array}{l}\text { International Journal of } \\
\text { Human Resource } \\
\text { Management }\end{array}$ & 182 \\
\hline
\end{tabular}

1980s: 1,346 journals

1990s: 1,765 journals

2000s: 2,126 journals 
Table 10 Top 20 Web of Science 'subject areas' of journals citing the core knowledge

\begin{tabular}{|c|c|l|}
\hline Rank & Frequency & Subject Areas \\
\hline 1 & 11,724 & Business \\
\hline 2 & 10,776 & Economics \\
\hline 3 & 4,738 & Management \\
\hline 4 & 2,760 & Sociology \\
\hline 5 & 2,610 & Business, Finance \\
\hline 6 & 1,997 & Law \\
\hline 7 & 1,807 & Environmental Studies \\
\hline 8 & 1,341 & Political Science \\
\hline 9 & 903 & Psychology \\
\hline 10 & 807 & Computer Science, Information Systems \\
\hline 11 & 769 & Social Sciences, Interdisciplinary \\
\hline 12 & 746 & Psychology, Applied \\
\hline 13 & 737 & Engineering \\
\hline 14 & 730 & Education \& Educational Research \\
\hline 15 & 615 & Public Administration \\
\hline 16 & 614 & Engineering, Industrial \\
\hline 17 & 568 & History \\
\hline 18 & 566 & Computer Science \\
\hline 19 & 559 & Planning \& Development \\
\hline 20 & 556 & Geography \\
\hline
\end{tabular}

This only draws on the first and thus main subject category in the case of journals that have more than one. Categories have been merged, such as different variation of computer science, except in cases where the subcategory (e.g. 'Computer Science, Information Systems') has large frequencies on their own. This should provide a more accurate representation of from which subjects journals citing the knowledge base come from. 
Table 11 Top 20 Web of Science 'subject areas' of journals citing the core knowledge over time

\begin{tabular}{|c|c|c|c|c|c|c|}
\hline & 1980s & & 1990s & & 2000s & \\
\hline Rank & Freq & Subject Categories & Freq & Subject Categories & Freq & Subject Categories \\
\hline 1 & 1906 & Economics & 3513 & Economics & 6484 & Business \\
\hline 2 & 1458 & Business & 3501 & Business & 4004 & Economics \\
\hline 3 & 584 & Sociology & 1347 & Management & 3030 & Management \\
\hline 4 & 508 & Law & 834 & Sociology & 1291 & Business, Finance \\
\hline 5 & 488 & Business, Finance & 671 & Business, Finance & 1145 & Environmental Studies \\
\hline 6 & 283 & Management & 668 & Law & 819 & Sociology \\
\hline 7 & 262 & Political Science & 496 & Environmental Studies & 651 & Law \\
\hline 8 & 212 & Psychology & 437 & Political Science & 518 & Engineering \\
\hline 9 & 159 & History & 244 & Psychology, Applied & 501 & Engineering, Industrial \\
\hline 10 & 154 & $\begin{array}{l}\text { Education \& } \\
\text { Educational Research }\end{array}$ & 241 & $\begin{array}{l}\text { Computer Science, } \\
\text { Information Systems }\end{array}$ & 500 & $\begin{array}{l}\text { Computer Science, } \\
\text { Information Systems }\end{array}$ \\
\hline 11 & 145 & $\begin{array}{l}\text { Social Sciences, } \\
\text { Interdisciplinary }\end{array}$ & 232 & Public Administration & 443 & Political Science \\
\hline 12 & 138 & Environmental Studies & 225 & $\begin{array}{l}\text { Planning \& } \\
\text { Development }\end{array}$ & 402 & Computer Science \\
\hline 13 & 132 & Psychology, Social & 220 & Psychology & 328 & Psychology, Applied \\
\hline 14 & 130 & Public Administration & 216 & $\begin{array}{l}\text { Social Sciences, } \\
\text { Interdisciplinary }\end{array}$ & 288 & Geography \\
\hline 15 & 122 & Psychology, Applied & 212 & $\begin{array}{l}\text { Education \& } \\
\text { Educational Research }\end{array}$ & 243 & $\begin{array}{l}\text { Social Sciences, } \\
\text { Interdisciplinary }\end{array}$ \\
\hline 16 & 91 & Computer Science & 208 & International Relations & 234 & Public Administration \\
\hline 17 & 86 & Anthropology & 204 & Geography & 230 & $\begin{array}{l}\text { Industrial Relations \& } \\
\text { Labor }\end{array}$ \\
\hline 18 & 85 & $\begin{array}{l}\text { Industrial Relations \& } \\
\text { Labor }\end{array}$ & 177 & $\begin{array}{l}\text { Industrial Relations \& } \\
\text { Labor }\end{array}$ & 222 & $\begin{array}{l}\text { Planning \& } \\
\text { Development }\end{array}$ \\
\hline 19 & 83 & $\begin{array}{l}\text { Humanities, } \\
\text { Multidisciplinary }\end{array}$ & 173 & Engineering & 196 & $\begin{array}{l}\text { Information Science \& } \\
\text { Library Science }\end{array}$ \\
\hline 20 & 81 & $\begin{array}{l}\text { Planning \& } \\
\text { Development }\end{array}$ & 166 & History & 190 & $\begin{array}{l}\text { Education \& } \\
\text { Educational Research }\end{array}$ \\
\hline
\end{tabular}


Figure 1a Clusters of scholars during the 1980s

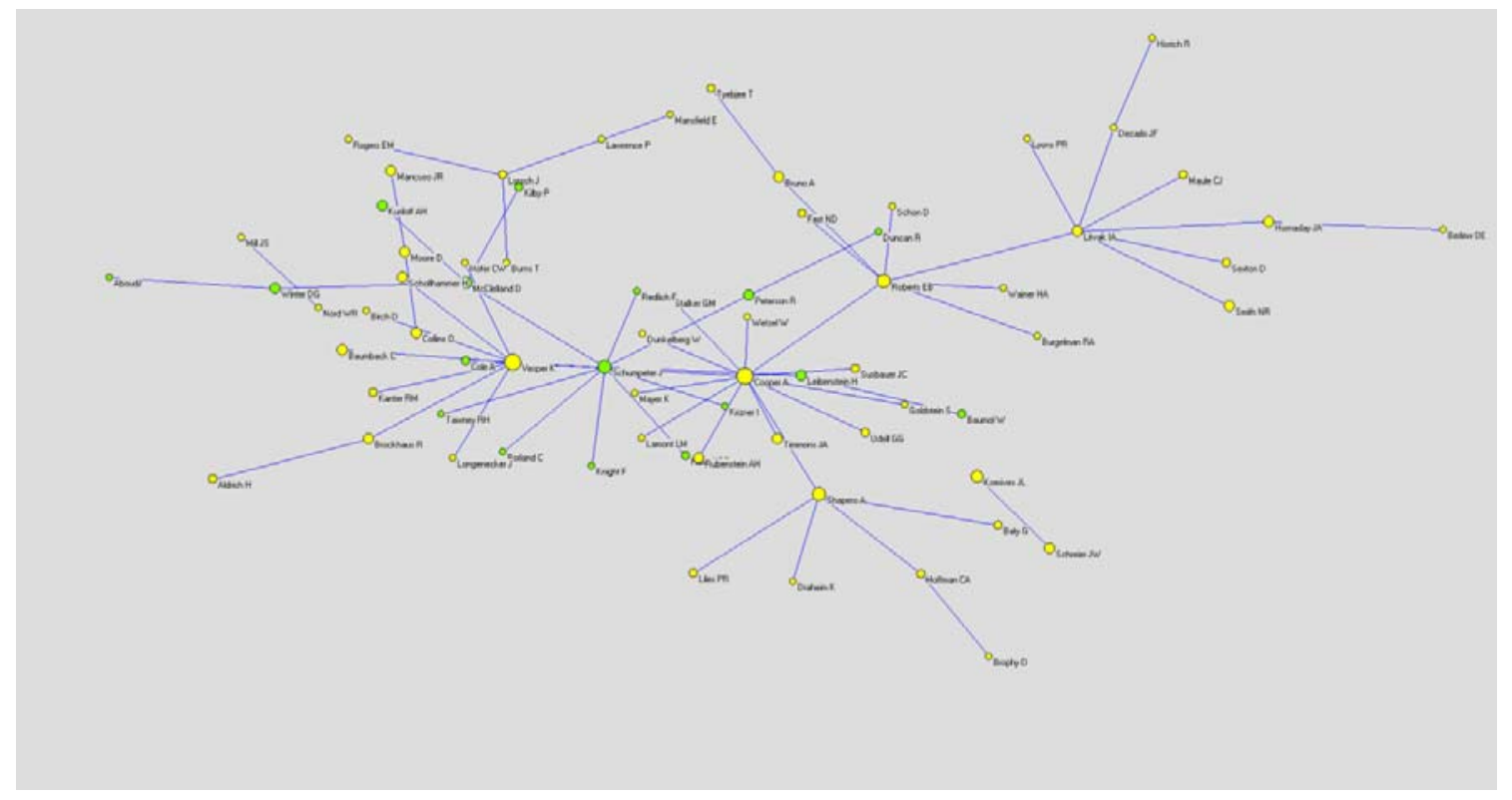

Figure 1b Clusters of scholars during the 1990s

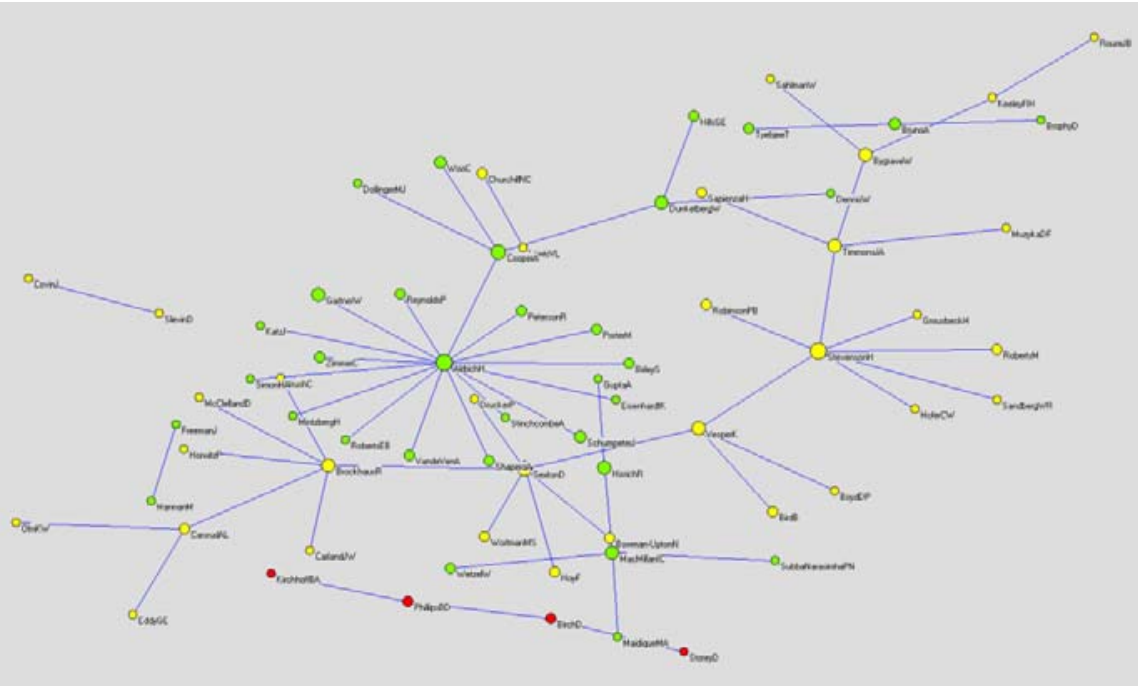


Figure 1c Clusters of scholars during the 2000s

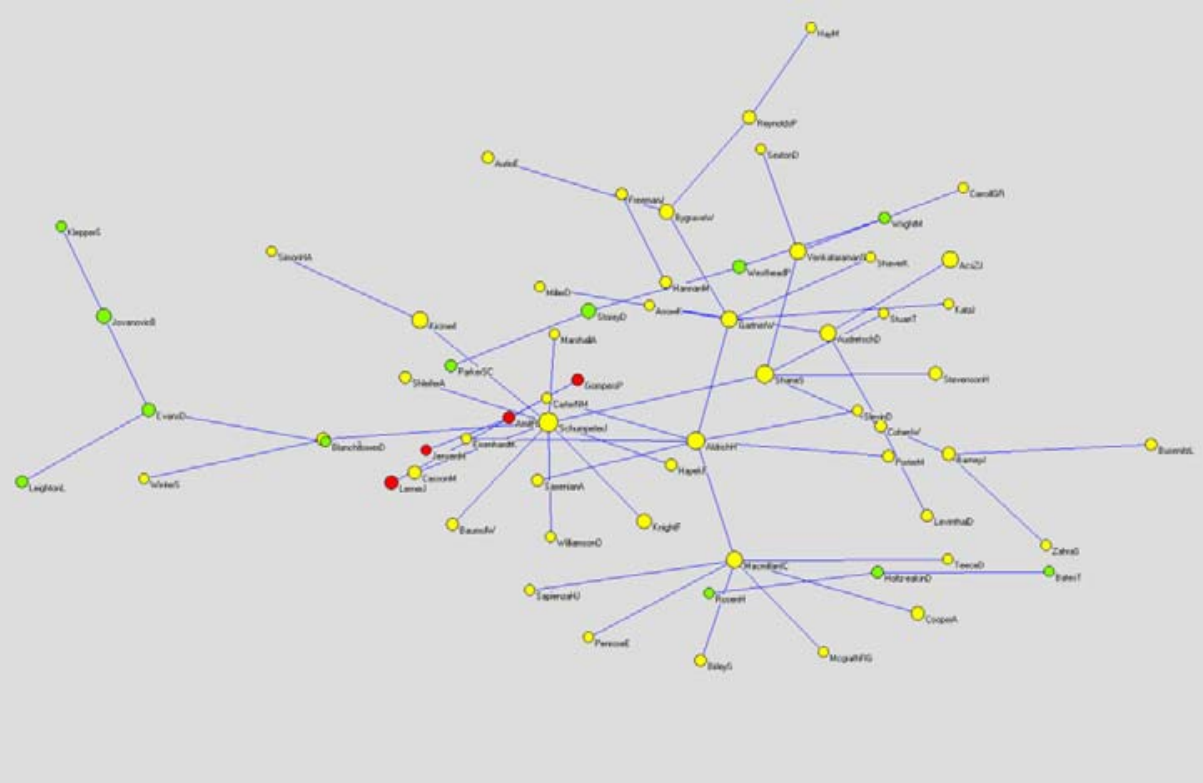


Figure 2 Top research institutions in entrepreneurship (total J-index)

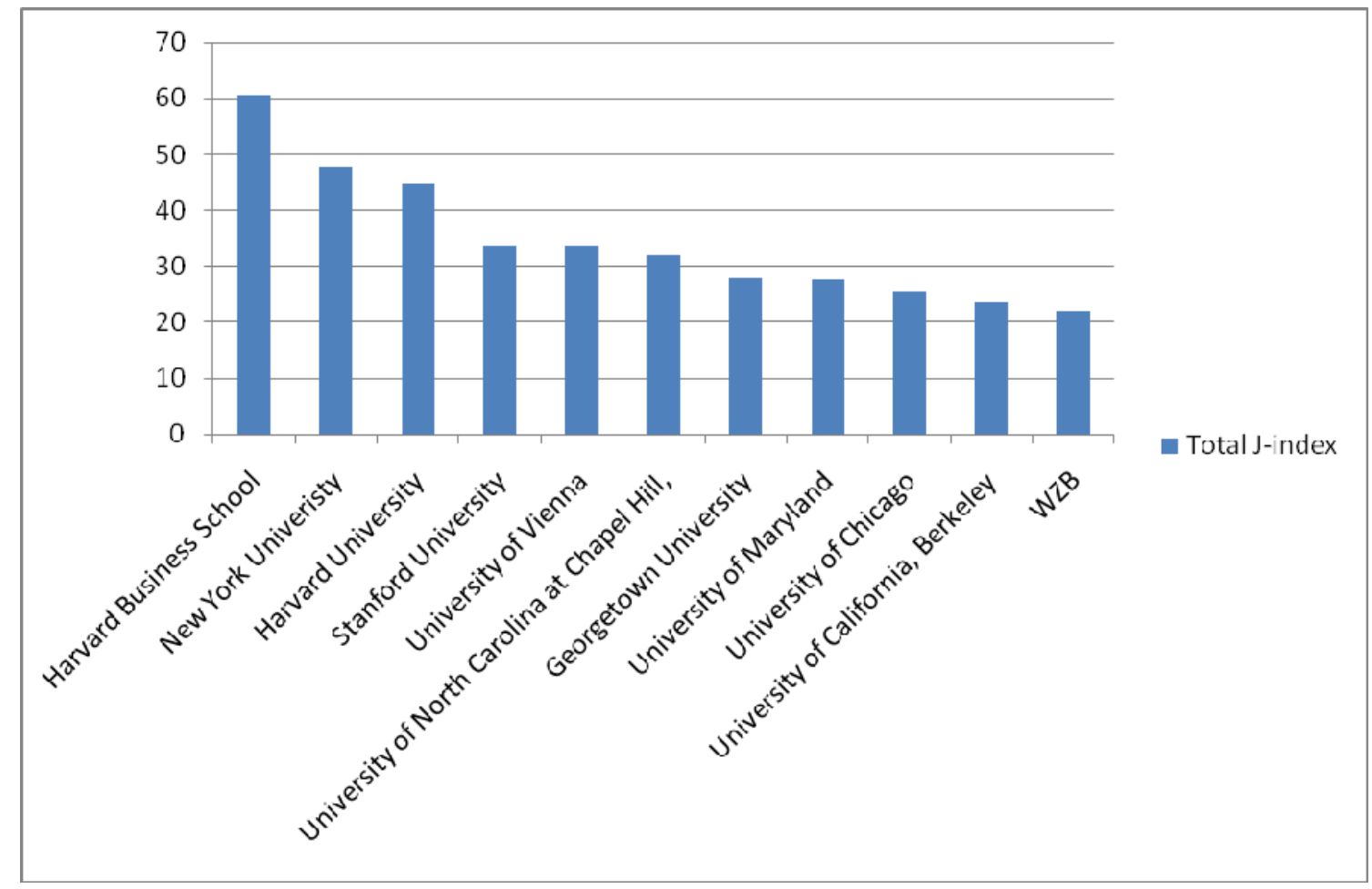


Figure 3a Co-occurrence of Web of Science 'subject areas' of journals citing the core knowledge producers during the $1980 \mathrm{~s}$

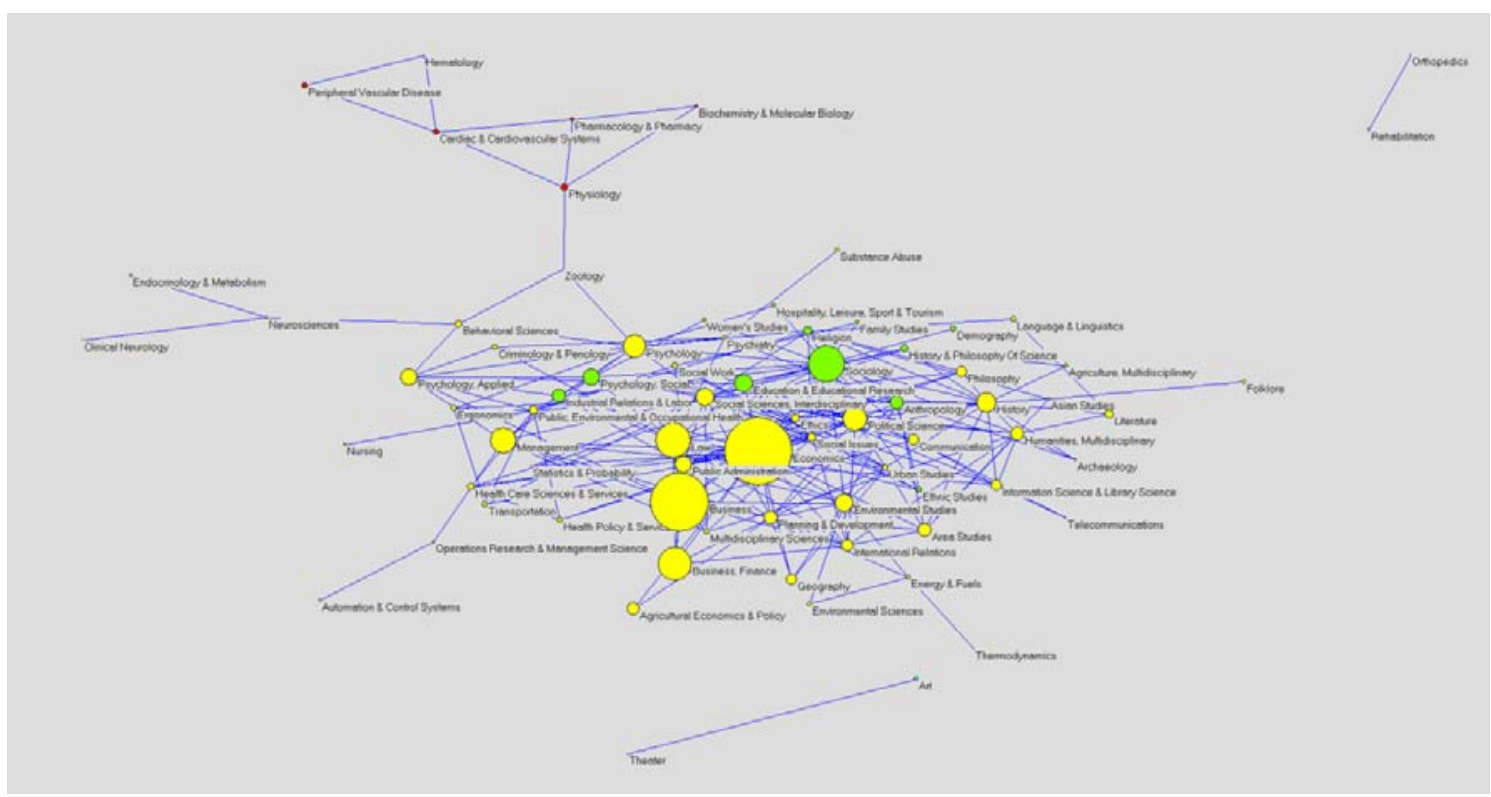

Figure 3b Co-occurrence of Web of Science 'subject areas' of journals citing the core knowledge producers during the 1990s

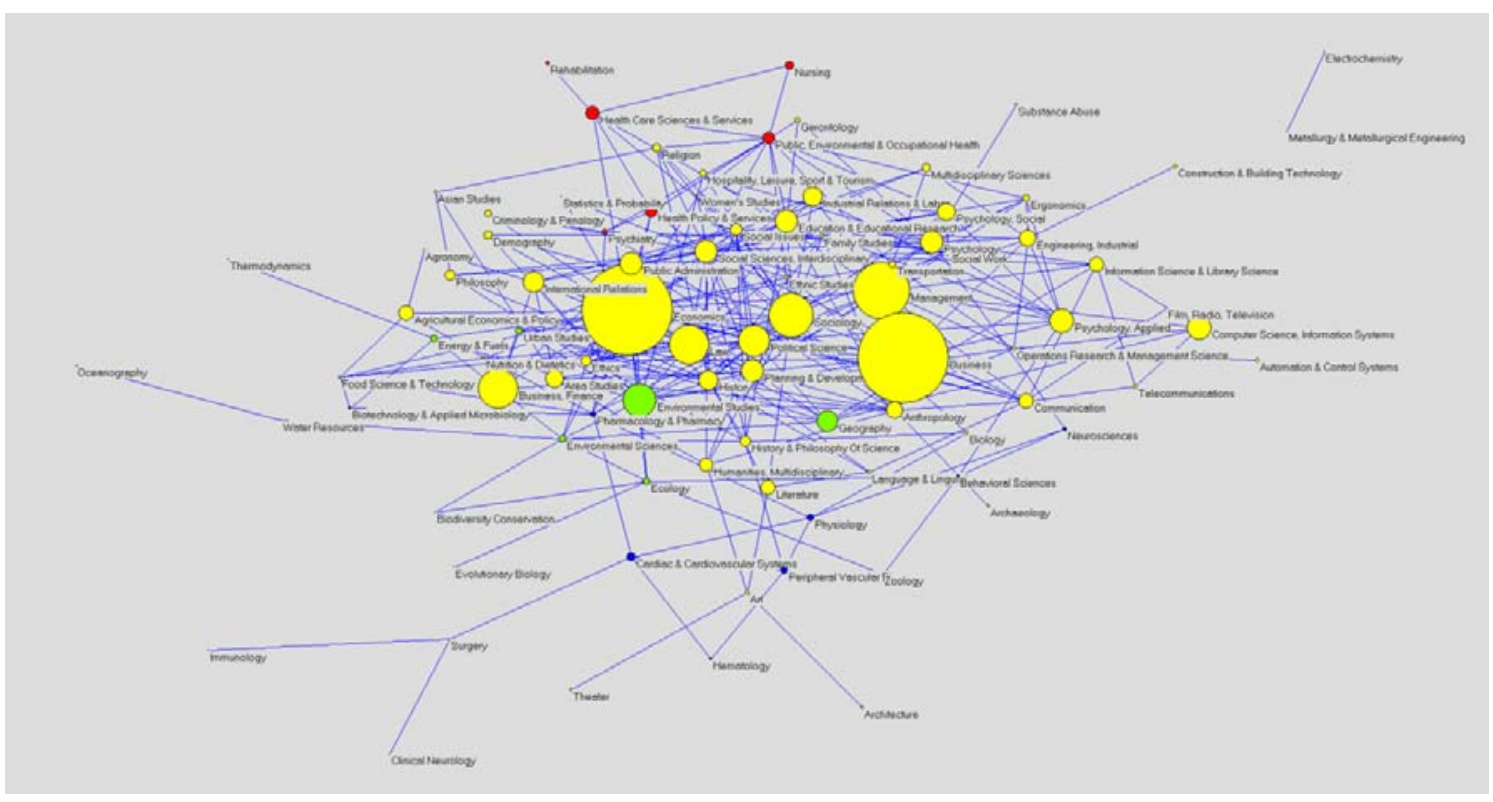


Figure 3c Co-occurrence of Web of Science 'subject areas' of journals citing the core knowledge producers during the 2000 s

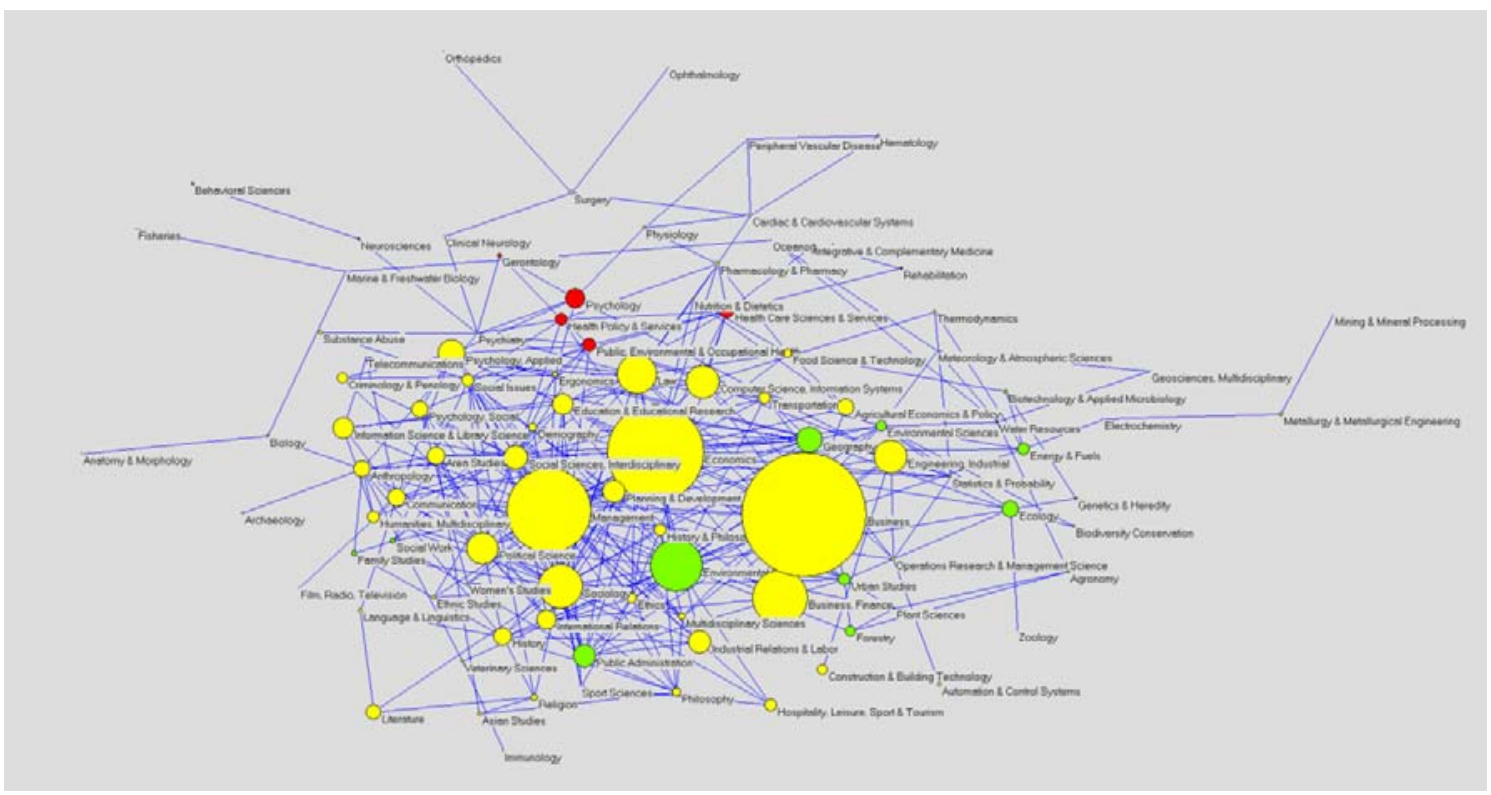




\begin{tabular}{|c|c|c|c|c|c|c|c|c|}
\hline \multicolumn{9}{|c|}{ APPENDIX 1} \\
\hline Rank & Year & Author & Title & Type & Journal & $\begin{array}{l}J- \\
\text { index }\end{array}$ & $\begin{array}{l}\text { SSCI } \\
\text { Citation }\end{array}$ & $\begin{array}{l}\text { SSCI/ } \\
\text { Year }\end{array}$ \\
\hline 1 & 1934 & Schumpeter, J. & $\begin{array}{l}\text { The theory of economic } \\
\text { development, Cambridge: } \\
\text { Harvard University. }\end{array}$ & Book & & 33.51 & 2967 & 57.06 \\
\hline 2 & 2000 & $\begin{array}{l}\text { Shane, S. and } \\
\text { Venkataraman, S. }\end{array}$ & $\begin{array}{l}\text { The promise of } \\
\text { entrepreneurship as a field of } \\
\text { research. }\end{array}$ & Journal & $\begin{array}{l}\text { Academy of } \\
\text { Management } \\
\text { Review }\end{array}$ & 22.97 & 342 & 42.75 \\
\hline 3 & 2000 & Shane, S. & $\begin{array}{l}\text { Prior knowledge and the } \\
\text { discovery of entrepreneurial } \\
\text { opportunities. }\end{array}$ & Journal & $\begin{array}{l}\text { Organization } \\
\text { Science }\end{array}$ & 16.22 & 180 & 22.50 \\
\hline 4 & 1921 & Knight, F. & $\begin{array}{l}\text { Risk, Uncertainty and } \\
\text { Profit, Chicago: University } \\
\text { of Chicago Press. }\end{array}$ & Book & & 15.68 & 1765 & 33.94 \\
\hline 5 & 1942 & Schumpeter, J. & $\begin{array}{l}\text { Capitalism, socialism and } \\
\text { democracy: Can capitalism } \\
\text { survive?, New York: Harper } \\
\text { and Brothers. }\end{array}$ & Book & & 13.51 & 4846 & 93.19 \\
\hline 6 & 1988 & Gartner, W. & $\begin{array}{l}\text { "Who is an entrepreneur?" Is } \\
\text { the wrong question. }\end{array}$ & Journal & $\begin{array}{l}\text { American } \\
\text { Journal of } \\
\text { Small } \\
\text { Business }\end{array}$ & 12.85 & 217 & 10.85 \\
\hline 7 & 2000 & Bhidé, A. & $\begin{array}{l}\text { The Origin and Evolution of } \\
\text { New Businesses, New York: } \\
\text { Oxford University Press. }\end{array}$ & Book & & 12.16 & 106 & 13.25 \\
\hline 8 & 1973 & Kirzner, I. & $\begin{array}{l}\text { Competition and } \\
\text { Entrepreneurship, Chicago: } \\
\text { University of Chicago. }\end{array}$ & Book & & 11.89 & 592 & 16.91 \\
\hline 9 & 1961 & McClelland, D. & $\begin{array}{l}\text { The Achieving Society, } \\
\text { Princeton, NJ: Van } \\
\text { Nostrand. }\end{array}$ & Book & & 11.89 & 2694 & 57.32 \\
\hline 10 & 1994 & Storey, D. & $\begin{array}{l}\text { Understanding the Small } \\
\text { Business Sector, London: } \\
\text { Routledge. }\end{array}$ & Book & & 11.63 & 474 & 33.86 \\
\hline 11 & 1997 & Kirzner, I. & $\begin{array}{l}\text { Entrepreneurial discovery } \\
\text { and the competitive market } \\
\text { process: An Austrian } \\
\text { approach. }\end{array}$ & Journal & $\begin{array}{l}\text { Journal of } \\
\text { Economic } \\
\text { Literature }\end{array}$ & 11.46 & 172 & 15.64 \\
\hline 12 & 1982 & Casson, M. & $\begin{array}{l}\text { The entrepreneur: An } \\
\text { economic theory, Oxford: } \\
\text { Martin Robertson. }\end{array}$ & Book & & 11.38 & 184 & 7.08 \\
\hline 13 & 1986 & $\begin{array}{l}\text { Aldrich, H. and } \\
\text { Zimmer, C. }\end{array}$ & $\begin{array}{l}\text { Entrepreneurship through } \\
\text { Social Networks, in D. } \\
\text { Sexton and R. Smilor (eds), } \\
\text { The Art and Science of } \\
\text { Entrepreneurship, New } \\
\text { York: Ballinger. }\end{array}$ & $\begin{array}{l}\text { Book } \\
\text { chapter }\end{array}$ & & 10.90 & 204 & 9.27 \\
\hline 14 & 1994 & Saxenian, A. & $\begin{array}{l}\text { Regional Advantage: } \\
\text { Culture and Competition in } \\
\text { Silicon Valley and Route } \\
\text { 128, Cambridge, MA: } \\
\text { Harvard University Press. }\end{array}$ & Book & & 10.85 & 1236 & 88.29 \\
\hline
\end{tabular}




\begin{tabular}{|c|c|c|c|c|c|c|c|c|}
\hline 15 & 1997 & Venkataraman, S. & $\begin{array}{l}\text { The distinctive domain of } \\
\text { entrepreneurship research, in } \\
\text { J. Katz and R. Brockhaus } \\
\text { (eds), Advances in } \\
\text { Entrepreneurship, Firm } \\
\text { Emergence and Growth, } \\
\text { Greenwich, CT: JAI Press. }\end{array}$ & $\begin{array}{l}\text { Book } \\
\text { chapter }\end{array}$ & & 10.42 & 177 & 16.09 \\
\hline 16 & 1965 & Stinchcombe, A. & $\begin{array}{l}\text { Social structure and } \\
\text { organizations, in J.G. March } \\
\text { (ed), Handbook of } \\
\text { Organizations, Chicago: } \\
\text { Rand-McNally. }\end{array}$ & $\begin{array}{l}\text { Book } \\
\text { chapter }\end{array}$ & & 9.73 & 1289 & 29.98 \\
\hline 17 & 1959 & Penrose, E. & $\begin{array}{l}\text { The Theory of the Growth of } \\
\text { the Firm, Oxford: Oxford } \\
\text { University Press. }\end{array}$ & Book & & 9.73 & 2169 & 44.27 \\
\hline 18 & 1982 & $\begin{array}{l}\text { Nelson, R. and } \\
\text { Winter, S. }\end{array}$ & $\begin{array}{l}\text { An Evolutionary Theory of } \\
\text { Economic Change, } \\
\text { Cambridge, MA: Harvard } \\
\text { University Press. }\end{array}$ & Book & & 9.58 & 4303 & 165.50 \\
\hline 19 & 2000 & Hamilton, B. & $\begin{array}{l}\text { Does Entrepreneurship Pay? } \\
\text { An Empirical Analysis of } \\
\text { the Returns to Self- } \\
\text { employment. }\end{array}$ & Journal & $\begin{array}{l}\text { Journal of } \\
\text { Political } \\
\text { Economy }\end{array}$ & 9.46 & 78 & 9.75 \\
\hline 20 & 1999 & Aldrich, H. & $\begin{array}{l}\text { Organizations Evolving, } \\
\text { London: Sage. }\end{array}$ & Book & & 9.38 & 457 & 50.78 \\
\hline 21 & 1998 & $\begin{array}{l}\text { Blanchflower, D. } \\
\text { and Oswald, A. }\end{array}$ & $\begin{array}{l}\text { What Makes an } \\
\text { Entrepreneur? }\end{array}$ & Journal & $\begin{array}{l}\text { Journal of } \\
\text { Labor } \\
\text { Economics }\end{array}$ & 9.38 & 194 & 19.40 \\
\hline 22 & 1997 & $\begin{array}{l}\text { Busenitz, L. and } \\
\text { Barney, J. }\end{array}$ & $\begin{array}{l}\text { Differences between } \\
\text { entrepreneurs and managers } \\
\text { in large organizations: } \\
\text { Biases and heuristics in } \\
\text { strategic decision-making. }\end{array}$ & Journal & $\begin{array}{l}\text { Journal of } \\
\text { Business } \\
\text { Venturing }\end{array}$ & 9.38 & 163 & 14.82 \\
\hline 23 & 1989 & $\begin{array}{l}\text { Evans, D. and } \\
\text { Jovanovic, B. }\end{array}$ & $\begin{array}{l}\text { An Estimated Model of } \\
\text { Entrepreneurial Choice } \\
\text { Under Liquidity Constraints. }\end{array}$ & Journal & $\begin{array}{l}\text { Journal of } \\
\text { Political } \\
\text { Economy }\end{array}$ & 8.97 & 321 & 16.89 \\
\hline 24 & 1985 & Drucker, P. & $\begin{array}{l}\text { Innovation and } \\
\text { entrepreneurship: practice } \\
\text { and principles, New York: } \\
\text { Harper and Row. }\end{array}$ & Book & & 8.38 & 518 & 22.52 \\
\hline 25 & 1997 & ENSR & $\begin{array}{l}\text { The European Observatory } \\
\text { for SMEs, Fifth Annual } \\
\text { Report to the European } \\
\text { Commission, EIM, } \\
\text { Netherlands. }\end{array}$ & Report & & 8.33 & 16 & 1.45 \\
\hline 26 & 1990 & $\begin{array}{l}\text { Stevenson, H. and } \\
\text { Jarillo, J. }\end{array}$ & $\begin{array}{l}\text { A Paradigm of } \\
\text { Entrepreneurship: } \\
\text { Entrepreneurial } \\
\text { Management. }\end{array}$ & Journal & $\begin{array}{l}\text { Strategic } \\
\text { Management } \\
\text { Journal }\end{array}$ & 8.33 & 157 & 8.72 \\
\hline 27 & 1988 & $\begin{array}{l}\text { Low, M. and } \\
\text { MacMillan, I. }\end{array}$ & $\begin{array}{l}\text { Entrepreneurship: Past } \\
\text { research and future } \\
\text { challenges. }\end{array}$ & Journal & $\begin{array}{l}\text { Journal of } \\
\text { Management }\end{array}$ & 8.33 & 182 & 9.10 \\
\hline
\end{tabular}




\begin{tabular}{|c|c|c|c|c|c|c|c|c|}
\hline 28 & 1996 & $\begin{array}{l}\text { Lumpkin, G.T. } \\
\text { and Dess, G.G. }\end{array}$ & $\begin{array}{l}\text { Clarifying the } \\
\text { Entrepreneurial Orientation } \\
\text { Construct and Linking It to } \\
\text { Performance. }\end{array}$ & Journal & $\begin{array}{l}\text { Academy of } \\
\text { Management } \\
\text { Review }\end{array}$ & 8.26 & 273 & 22.75 \\
\hline 29 & 1995 & Audretsch, D. & $\begin{array}{l}\text { Innovation and Industry } \\
\text { Evolution, Cambridge: MIT } \\
\text { Press. }\end{array}$ & Book & & 8.26 & 280 & 21.54 \\
\hline 30 & 2001 & $\begin{array}{l}\text { Alvarez, S.A. and } \\
\text { Busenitz, L. }\end{array}$ & $\begin{array}{l}\text { The entrepreneurship of } \\
\text { resource-based theory. }\end{array}$ & Journal & $\begin{array}{l}\text { Journal of } \\
\text { Management }\end{array}$ & 8.11 & 62 & 8.86 \\
\hline 31 & 2001 & $\begin{array}{l}\text { Reynolds, P., } \\
\text { Camp, S.M., } \\
\text { Bygrave, W., } \\
\text { Autio, E. and } \\
\text { Hay, M. }\end{array}$ & $\begin{array}{l}\text { Global Entrepreneurship } \\
\text { Monitor. } 2001 \text { Executive } \\
\text { Report, Kauffman } \\
\text { Foundation, Kansas, MO. }\end{array}$ & Report & & 8.11 & 55 & 7.86 \\
\hline 32 & 1985 & Gartner, W. & $\begin{array}{l}\text { A conceptual framework for } \\
\text { describing the phenomenon } \\
\text { of new venture creation. }\end{array}$ & Journal & $\begin{array}{l}\text { Academy of } \\
\text { Management } \\
\text { Review }\end{array}$ & 7.78 & 192 & 8.35 \\
\hline 33 & 1982 & Jovanovic, B. & $\begin{array}{l}\text { Selection and the evolution } \\
\text { of industry. }\end{array}$ & Journal & Econometrica & 7.78 & 628 & 24.15 \\
\hline 34 & 1991 & $\begin{array}{l}\text { Shaver, K. and } \\
\text { Scott, L. }\end{array}$ & $\begin{array}{l}\text { Person, Process, Choice: } \\
\text { The Psychology of New } \\
\text { Venture Creation. }\end{array}$ & Journal & $\begin{array}{l}\text { Entrepreneur- } \\
\text { ship Theory } \\
\text { and Practice }\end{array}$ & 7.69 & 95 & 5.59 \\
\hline 35 & 1990 & $\begin{array}{l}\text { Cohen, W. and } \\
\text { Levinthal, D. }\end{array}$ & $\begin{array}{l}\text { Absorptive Capacity: A New } \\
\text { Perspective on Learning and } \\
\text { Innovation. }\end{array}$ & Journal & $\begin{array}{l}\text { Administrative } \\
\text { Science } \\
\text { Quarterly }\end{array}$ & 7.69 & 2245 & 124.72 \\
\hline 36 & 1989 & $\begin{array}{l}\text { Evans, D. and } \\
\text { Leighton, L. }\end{array}$ & $\begin{array}{l}\text { Some empirical aspects of } \\
\text { entrepreneurship. }\end{array}$ & Journal & $\begin{array}{l}\text { American } \\
\text { Economic } \\
\text { Review }\end{array}$ & 7.69 & 288 & 15.16 \\
\hline 37 & 1986 & $\begin{array}{l}\text { Brockhaus, R. and } \\
\text { Horwitz, P. }\end{array}$ & $\begin{array}{l}\text { The psychology of the } \\
\text { entrepreneur, in D. Sexton } \\
\text { and R. Smilor (eds),The Art } \\
\text { and Science of } \\
\text { Entrepreneurship, } \\
\text { Cambridge: Ballinger. }\end{array}$ & $\begin{array}{l}\text { Book } \\
\text { chapter }\end{array}$ & & 7.69 & 95 & 4.32 \\
\hline 38 & 1980 & Vesper, K. & $\begin{array}{l}\text { New venture strategies, } \\
\text { Englewood Cliffs, NJ: } \\
\text { Prentice Hall. }\end{array}$ & Book & & 7.57 & 177 & 6.32 \\
\hline 39 & 1979 & Birch, D. & $\begin{array}{l}\text { The job generation process, } \\
\text { MIT Program for } \\
\text { Neighborhood and Regional } \\
\text { Change, Cambridge, MA: } \\
\text { MIT. }\end{array}$ & Report & & 7.57 & 320 & 11.03 \\
\hline 40 & 1976 & $\begin{array}{l}\text { Jensen, M. and } \\
\text { Meckling, W.H. }\end{array}$ & $\begin{array}{l}\text { Theory of the firm: } \\
\text { Managerial behavior, agency } \\
\text { costs and ownership } \\
\text { structure. }\end{array}$ & Journal & $\begin{array}{l}\text { Journal of } \\
\text { Financial } \\
\text { Economics }\end{array}$ & 7.57 & 5361 & 167.53 \\
\hline 41 & 1999 & $\begin{array}{l}\text { Gompers, P. and } \\
\text { Lerner, J. }\end{array}$ & $\begin{array}{l}\text { The Venture Capital Cycle, } \\
\text { Cambridge, MA: MIT Press. }\end{array}$ & Book & & 7.29 & 196 & 21.78 \\
\hline 42 & 1999 & Lerner, J. & $\begin{array}{l}\text { The Government as Venture } \\
\text { Capitalist: The Long Run } \\
\text { Impact of the SBIR } \\
\text { Program. }\end{array}$ & Journal & $\begin{array}{l}\text { Journal of } \\
\text { Business }\end{array}$ & 7.29 & 67 & 7.44 \\
\hline
\end{tabular}




\begin{tabular}{|c|c|c|c|c|c|c|c|c|}
\hline 43 & 1998 & Caves, R.E. & $\begin{array}{l}\text { Industrial Organization and } \\
\text { New Findings on the } \\
\text { Turnover and Mobility of } \\
\text { Firms. }\end{array}$ & Journal & $\begin{array}{l}\text { Journal of } \\
\text { Economic } \\
\text { Literature }\end{array}$ & 7.29 & 197 & 19.70 \\
\hline 44 & 1987 & Birch, D. & $\begin{array}{l}\text { Job creation in America: } \\
\text { how our smallest companies } \\
\text { put the most people to work, } \\
\text { New York: Free Press. }\end{array}$ & Book & & 7.05 & 252 & 12.00 \\
\hline 45 & 1986 & $\begin{array}{l}\text { Carsrud, A.L., } \\
\text { Olm, K.W. and } \\
\text { Eddy, G.E. }\end{array}$ & $\begin{array}{l}\text { Entrepreneurship: Research } \\
\text { in quest of a paradigm, in D. } \\
\text { Sexton and R. Smilor (eds), } \\
\text { The art and science of } \\
\text { entrepreneurship, } \\
\text { Cambridge, MA: Ballinger. }\end{array}$ & $\begin{array}{l}\text { Book } \\
\text { chapter }\end{array}$ & & 7.05 & 21 & 0.95 \\
\hline 46 & 1986 & Wortman, M.S. & $\begin{array}{l}\text { A unified framework, } \\
\text { research typologiesand } \\
\text { research prospectuses for the } \\
\text { interface between } \\
\text { entrepreneurship and small } \\
\text { business, in D. Sexton and } \\
\text { R. Smilor (eds), The Art and } \\
\text { Science of Entrepreneurship, } \\
\text { Cambridge, MA: Ballinger. }\end{array}$ & $\begin{array}{l}\text { Book } \\
\text { chapter }\end{array}$ & & 7.05 & 16 & 0.73 \\
\hline 47 & 1890 & Marshall, A. & $\begin{array}{l}\text { Principles of economics, } \\
\text { London: MacMillan. }\end{array}$ & Book & & 7.03 & 4013 & 77.17 \\
\hline 48 & 2002 & Lazear, E. P. & $\begin{array}{l}\text { Entrepreneurship, Working } \\
\text { Paper No 9109, Cambridge, } \\
\text { MA: NBER. }\end{array}$ & Report & & 6.76 & 19 & 3.17 \\
\hline 49 & 2001 & $\begin{array}{l}\text { Gaglio, C. and } \\
\text { Katz, J. }\end{array}$ & $\begin{array}{l}\text { The psychological basis of } \\
\text { opportunity identification: } \\
\text { entrepreneurial alertness. }\end{array}$ & Journal & $\begin{array}{l}\text { Small } \\
\text { Business } \\
\text { Economics }\end{array}$ & 6.76 & 43 & 6.14 \\
\hline 50 & 2000 & $\begin{array}{l}\text { Reynolds, P., } \\
\text { Hay, M., } \\
\text { Bygrave, W., } \\
\text { Camp, M. and } \\
\text { Autio, E. }\end{array}$ & $\begin{array}{l}\text { Global Entrepreneurship } \\
\text { Monitor: } 2000 \text { Executive } \\
\text { Report, Kansas City: } \\
\text { Kauffman Center for } \\
\text { Entrepreneurial Leadership. }\end{array}$ & Report & & 6.76 & 48 & 6.00 \\
\hline 51 & 2000 & $\begin{array}{l}\text { Sorenson, O. and } \\
\text { Audia, P.G. }\end{array}$ & $\begin{array}{l}\text { The social structure of } \\
\text { entrepreneurial activity: } \\
\text { Geographic concentration of } \\
\text { footwear production in the } \\
\text { United States, 1940- } 1989 \text {. }\end{array}$ & Journal & $\begin{array}{l}\text { American } \\
\text { Journal of } \\
\text { Sociology }\end{array}$ & 6.76 & 92 & 11.50 \\
\hline 52 & 1995 & Gompers, P. & $\begin{array}{l}\text { Optimal investing, } \\
\text { monitoring and the staging } \\
\text { of venture capital. }\end{array}$ & Journal & $\begin{array}{l}\text { Journal of } \\
\text { Finance }\end{array}$ & 6.61 & 156 & 12.00 \\
\hline 53 & 1984 & $\begin{array}{l}\text { Hannan, M. and } \\
\text { Freeman, J. }\end{array}$ & $\begin{array}{l}\text { Structural inertia and } \\
\text { organizational change. }\end{array}$ & Journal & $\begin{array}{l}\text { American } \\
\text { Sociological } \\
\text { Review }\end{array}$ & 6.59 & 1058 & 44.08 \\
\hline 54 & 1980 & Porter, M. & $\begin{array}{l}\text { Competitive Strategy, New } \\
\text { York: Free Press. }\end{array}$ & Book & & 6.49 & 4533 & 161.89 \\
\hline 55 & 1945 & Hayek, F. & $\begin{array}{l}\text { The use of knowledge in } \\
\text { society. }\end{array}$ & Journal & $\begin{array}{l}\text { American } \\
\text { Economic } \\
\text { Review }\end{array}$ & 6.49 & 1014 & 19.50 \\
\hline 56 & 1991 & Barney, J. & $\begin{array}{l}\text { Firm Resources and } \\
\text { Sustained Competitive } \\
\text { Advantage. }\end{array}$ & Journal & $\begin{array}{l}\text { Journal of } \\
\text { Management }\end{array}$ & 6.41 & 2708 & 159.29 \\
\hline
\end{tabular}




\begin{tabular}{|c|c|c|c|c|c|c|c|c|}
\hline 57 & 1994 & $\begin{array}{l}\text { Holtz-Eakin, D., } \\
\text { Joulfaian, D. and } \\
\text { Rosen, H. }\end{array}$ & $\begin{array}{l}\text { Sticking it Out: } \\
\text { Entrepreneurial Survival and } \\
\text { Liquidity Constraints. }\end{array}$ & Journal & $\begin{array}{l}\text { Journal of } \\
\text { Political } \\
\text { Economy }\end{array}$ & 6.20 & 148 & 10.57 \\
\hline 58 & 1985 & Birley, S. & $\begin{array}{l}\text { The role of networks in the } \\
\text { entrepreneurial process. }\end{array}$ & Journal & $\begin{array}{l}\text { Journal of } \\
\text { Business } \\
\text { Venturing } \\
\end{array}$ & 5.99 & 155 & 6.74 \\
\hline 59 & 1985 & $\begin{array}{l}\text { Stevenson, H., } \\
\text { Roberts, M. and } \\
\text { Grousbeck, H. }\end{array}$ & $\begin{array}{l}\text { New Business Ventures and } \\
\text { the Entrepreneur, } \\
\text { Homewood, IL: Irwin. }\end{array}$ & Book & & 5.99 & 78 & 3.39 \\
\hline 60 & 1982 & $\begin{array}{l}\text { Kent, C.A., } \\
\text { Sexton, D. and } \\
\text { Vesper, K. }\end{array}$ & $\begin{array}{l}\text { Encyclopedia of } \\
\text { entrepreneurship, } \\
\text { Englewood Cliffs, NJ: } \\
\text { Prentice-Hall. }\end{array}$ & Book & & 5.99 & 47 & 1.81 \\
\hline 61 & 1992 & $\begin{array}{l}\text { Bygrave, W. and } \\
\text { Timmons, J. }\end{array}$ & $\begin{array}{l}\text { Venture Capital at the } \\
\text { Crossroads, Boston, MA: } \\
\text { Harvard Business School } \\
\text { Press. }\end{array}$ & Book & & 5.97 & 164 & 10.25 \\
\hline 62 & 1992 & Larson, A. & $\begin{array}{l}\text { Network dyads in } \\
\text { entrepreneurial settings: A } \\
\text { study of the governance of } \\
\text { exchange relationships. }\end{array}$ & Journal & $\begin{array}{l}\text { Administrative } \\
\text { Science } \\
\text { Quarterly }\end{array}$ & 5.97 & 330 & 20.63 \\
\hline 63 & 1979 & Kirzner, I. & $\begin{array}{l}\text { Perception, opportunity and } \\
\text { profit: Studies in the Theory } \\
\text { of Entrepreneurship, } \\
\text { Chicago: University of } \\
\text { Chicago. }\end{array}$ & Book & & 5.95 & 248 & 8.55 \\
\hline 64 & 1977 & $\begin{array}{l}\text { Hannan, M. and } \\
\text { Freeman, J. }\end{array}$ & $\begin{array}{l}\text { The population ecology of } \\
\text { organizations. }\end{array}$ & Journal & $\begin{array}{l}\text { American } \\
\text { Journal of } \\
\text { Sociology }\end{array}$ & 5.95 & 1367 & 44.10 \\
\hline 65 & 1977 & $\begin{array}{l}\text { Timmons, J.A., } \\
\text { Smollen, L.E. and } \\
\text { Dingee, A. }\end{array}$ & $\begin{array}{l}\text { New Venture Creation, } \\
\text { Homewood, IL: Irwin. }\end{array}$ & Book & & 5.95 & 253 & 8.16 \\
\hline 66 & 1968 & Baumol, W. & $\begin{array}{l}\text { Entrepreneurship in } \\
\text { economic theory. }\end{array}$ & Journal & $\begin{array}{l}\text { American } \\
\text { Economic } \\
\text { Review } \\
\end{array}$ & 5.95 & 97 & 2.43 \\
\hline 67 & 1996 & $\begin{array}{l}\text { Audretsch, D. and } \\
\text { Feldman, M. }\end{array}$ & $\begin{array}{l}\text { R\&D Spillovers and the } \\
\text { Geography of Innovation } \\
\text { and Production. }\end{array}$ & Journal & $\begin{array}{l}\text { American } \\
\text { Economic } \\
\text { Review }\end{array}$ & 5.79 & 454 & 37.83 \\
\hline 68 & 1990 & $\begin{array}{l}\text { Acs, Z.J. and } \\
\text { Audretsch, D. }\end{array}$ & $\begin{array}{l}\text { Innovation and Small Firms, } \\
\text { Cambridge: MIT Press. }\end{array}$ & Book & & 5.77 & 288 & 16.00 \\
\hline 69 & 1990 & Baumol, W. & $\begin{array}{l}\text { Entrepreneurship: } \\
\text { Productive, unproductive } \\
\text { and destructive. }\end{array}$ & Journal & $\begin{array}{l}\text { Journal of } \\
\text { Political } \\
\text { Economy }\end{array}$ & 5.77 & 224 & 12.44 \\
\hline 70 & 1990 & Gartner, W. & $\begin{array}{l}\text { What are we talking about } \\
\text { when we talk about } \\
\text { entrepreneurship? }\end{array}$ & Journal & $\begin{array}{l}\text { Journal of } \\
\text { Business } \\
\text { Venturing }\end{array}$ & 5.77 & 61 & 3.39 \\
\hline 71 & 1986 & $\begin{array}{l}\text { Churchill, N.C. } \\
\text { and Lewis, V.L. }\end{array}$ & $\begin{array}{l}\text { Entrepreneurship research: } \\
\text { Directions and methods, in } \\
\text { D. Sexton and R. Smilor } \\
\text { (eds), The art and science of } \\
\text { entrepreneurship, } \\
\text { Cambridge, MA: Ballinger. }\end{array}$ & $\begin{array}{l}\text { Book } \\
\text { chapter }\end{array}$ & & 5.77 & 12 & 0.55 \\
\hline
\end{tabular}




\begin{tabular}{|c|c|c|c|c|c|c|c|c|}
\hline 72 & 1994 & $\begin{array}{l}\text { Aldrich, H. and } \\
\text { Fiol, C.M. }\end{array}$ & $\begin{array}{l}\text { Fools rush in? The } \\
\text { institutional context of } \\
\text { industry creation. }\end{array}$ & Journal & $\begin{array}{l}\text { Academy of } \\
\text { Management } \\
\text { Review }\end{array}$ & 5.43 & 283 & 20.21 \\
\hline 73 & 1994 & $\begin{array}{l}\text { Holtz-Eakin, D., } \\
\text { Joulfaian, D. and } \\
\text { Rosen, H. }\end{array}$ & $\begin{array}{l}\text { Entrepreneurial Decisions } \\
\text { and Liquidity Constraints. }\end{array}$ & Journal & $\begin{array}{l}\text { Rand Journal } \\
\text { of Economics }\end{array}$ & 5.43 & 111 & 7.93 \\
\hline 74 & 1993 & Baumol, W. & $\begin{array}{l}\text { Formal Entrepreneurship } \\
\text { Theory in Economics: } \\
\text { Existence and bounds. }\end{array}$ & Journal & $\begin{array}{l}\text { Journal of } \\
\text { Business } \\
\text { Venturing }\end{array}$ & 5.43 & 31 & 2.07 \\
\hline 75 & 2001 & $\begin{array}{l}\text { Blanchflower, D., } \\
\text { Oswald, A. and } \\
\text { Stutzer, A. }\end{array}$ & $\begin{array}{l}\text { Latent Entrepreneurship } \\
\text { across Nations. }\end{array}$ & Journal & $\begin{array}{l}\text { European } \\
\text { Economic } \\
\text { Review }\end{array}$ & 5.41 & 40 & 5.71 \\
\hline 76 & 2001 & Klepper, S. & $\begin{array}{l}\text { Employee Startups in High- } \\
\text { Tech Industries. }\end{array}$ & Journal & $\begin{array}{l}\text { Industrial and } \\
\text { Corporate } \\
\text { Change }\end{array}$ & 5.41 & 44 & 6.29 \\
\hline 77 & 2001 & Sarasvathy, S. & $\begin{array}{l}\text { Causation and effectuation: } \\
\text { Toward a theoretical shirt } \\
\text { from economic inevitability } \\
\text { to entrepreneurial } \\
\text { contingency. }\end{array}$ & Journal & $\begin{array}{l}\text { Academy of } \\
\text { Management } \\
\text { Review }\end{array}$ & 5.41 & 72 & 10.29 \\
\hline 78 & 2001 & $\begin{array}{l}\text { Sorenson, O. and } \\
\text { Stuart, T. }\end{array}$ & $\begin{array}{l}\text { Syndication networks and } \\
\text { the spatial distribution of } \\
\text { venture capital investments. }\end{array}$ & Journal & $\begin{array}{l}\text { American } \\
\text { Journal of } \\
\text { Sociology }\end{array}$ & 5.41 & 113 & 16.14 \\
\hline 79 & 2000 & $\begin{array}{l}\text { Birley, S. and } \\
\text { Stockley, S. }\end{array}$ & $\begin{array}{l}\text { Entrepreneurial Teams and } \\
\text { Venture Growth, in D. } \\
\text { Sexton and H. Landström } \\
\text { (eds), The Blackwell } \\
\text { Handbook of } \\
\text { Entrepreneurship, Oxford: } \\
\text { Blackwell. }\end{array}$ & $\begin{array}{l}\text { Book } \\
\text { chapter }\end{array}$ & & 5.41 & 18 & 2.25 \\
\hline 80 & 2000 & Blanchflower, D. & $\begin{array}{l}\text { Self-employment in OECD } \\
\text { Countries. }\end{array}$ & Journal & $\begin{array}{l}\text { Labor } \\
\text { Economics }\end{array}$ & 5.41 & 44 & 5.50 \\
\hline 81 & 2000 & $\begin{array}{l}\text { Carroll, G.R. and } \\
\text { Hannan, M. }\end{array}$ & $\begin{array}{l}\text { The Demography of } \\
\text { Corporations and Industries, } \\
\text { Princeton, NJ: Princeton } \\
\text { University Press }\end{array}$ & Book & & 5.41 & 284 & 35.50 \\
\hline 82 & 2000 & $\begin{array}{l}\text { Dunn, T.A. and } \\
\text { Holtz-Eakin, D. }\end{array}$ & $\begin{array}{l}\text { Financial capital, human } \\
\text { capital and the transition to } \\
\text { self-employment: evidence } \\
\text { from intergenerational links. }\end{array}$ & Journal & $\begin{array}{l}\text { Journal of } \\
\text { Labor } \\
\text { Economics }\end{array}$ & 5.41 & 55 & 6.88 \\
\hline 83 & 2000 & $\begin{array}{l}\text { Jeng, L.A. and } \\
\text { Wells, P. }\end{array}$ & $\begin{array}{l}\text { The Determinants of } \\
\text { Venture Capital Funding: } \\
\text { Evidence across Countries. }\end{array}$ & Journal & $\begin{array}{l}\text { Journal of } \\
\text { Corporate } \\
\text { Finance } \\
\end{array}$ & 5.41 & 45 & 5.63 \\
\hline 84 & 2000 & $\begin{array}{l}\text { Lin, Z., } \\
\text { Picot, G. and } \\
\text { Compton, J. }\end{array}$ & $\begin{array}{l}\text { The Entry and Exit } \\
\text { Dynamics of Self- } \\
\text { Employment in Canada. }\end{array}$ & Journal & $\begin{array}{l}\text { Small } \\
\text { Business } \\
\text { Economics }\end{array}$ & 5.41 & 8 & 1.00 \\
\hline 85 & 2000 & $\begin{array}{l}\text { Simon, M., } \\
\text { Houghton, S. and } \\
\text { Aquino, K. }\end{array}$ & $\begin{array}{l}\text { Cognitive biases, risk } \\
\text { perception and venture } \\
\text { formation. }\end{array}$ & Journal & $\begin{array}{l}\text { Journal of } \\
\text { Business } \\
\text { Venturing }\end{array}$ & 5.41 & 53 & 6.63 \\
\hline 86 & 1755 & Cantillon, R. & $\begin{array}{l}\text { Essai sur la nature de } \\
\text { commerce en géneral (Essay } \\
\text { on the nature of trade in } \\
\text { general). (ed. H. Higgs, } \\
\text { 1931), London: Macmillan }\end{array}$ & Book & & 5.41 & 243 & 4.67 \\
\hline
\end{tabular}




\begin{tabular}{|c|c|c|c|c|c|c|c|c|}
\hline 87 & 1985 & Granovetter, M. & $\begin{array}{l}\text { Economic action and social } \\
\text { structure: The problem of } \\
\text { embeddedness. }\end{array}$ & Journal & $\begin{array}{l}\text { American } \\
\text { Journal of } \\
\text { Sociology }\end{array}$ & 5.39 & 3637 & 158.13 \\
\hline 88 & 1985 & $\begin{array}{l}\text { Stevenson, H. and } \\
\text { Gumpert, D. }\end{array}$ & $\begin{array}{l}\text { The heart of } \\
\text { entrepreneurship. }\end{array}$ & Journal & $\begin{array}{l}\text { Harvard } \\
\text { Business } \\
\text { Review }\end{array}$ & 5.39 & 91 & 3.96 \\
\hline 89 & 1985 & Williamson, O. & $\begin{array}{l}\text { The Economic Institutions } \\
\text { of Capitalism, New York: } \\
\text { Free Press. }\end{array}$ & Book & & 5.39 & 5352 & 232.70 \\
\hline 90 & 1992 & $\begin{array}{l}\text { Chandler, G.N. } \\
\text { and Jansen, E. }\end{array}$ & $\begin{array}{l}\text { The founder's self-assessed } \\
\text { competence and venture } \\
\text { performance. }\end{array}$ & Journal & $\begin{array}{l}\text { Journal of } \\
\text { Business } \\
\text { Venturing }\end{array}$ & 5.22 & 38 & 2.38 \\
\hline 91 & 1999 & $\begin{array}{l}\text { Stuart, T., } \\
\text { Hoang, H. and } \\
\text { Hybels, R.C. }\end{array}$ & $\begin{array}{l}\text { Interorganizational } \\
\text { Endorsements and the } \\
\text { Performance of } \\
\text { Entrepreneurial Ventures. }\end{array}$ & Journal & $\begin{array}{l}\text { Administrative } \\
\text { Science } \\
\text { Quarterly }\end{array}$ & 5.21 & 221 & 24.56 \\
\hline 92 & 1998 & $\begin{array}{l}\text { Amit, R., } \\
\text { Brander, J. and } \\
\text { Zott, C. }\end{array}$ & $\begin{array}{l}\text { Why do Venture Capital } \\
\text { Firms Exist? Theory and } \\
\text { Canadian Evidence. }\end{array}$ & Journal & $\begin{array}{l}\text { Journal of } \\
\text { Business } \\
\text { Venturing }\end{array}$ & 5.21 & 43 & 4.30 \\
\hline 93 & 1998 & Baron, R. & $\begin{array}{l}\text { Cognitive Mechanisms in } \\
\text { Entrepreneurship: Why and } \\
\text { When Entrepreneurs Think } \\
\text { Differently than Other } \\
\text { People. }\end{array}$ & Journal & $\begin{array}{l}\text { Journal of } \\
\text { Business } \\
\text { Venturing }\end{array}$ & 5.21 & 93 & 9.30 \\
\hline 94 & 1998 & $\begin{array}{l}\text { Berger, A. and } \\
\text { Udell, G. }\end{array}$ & $\begin{array}{l}\text { The Economics of Small } \\
\text { Business Finance: The Roles } \\
\text { of Private Equity and Debt } \\
\text { Markets in the Financial } \\
\text { Growth Cycle. }\end{array}$ & Journal & $\begin{array}{l}\text { Journal of } \\
\text { Banking and } \\
\text { Finance }\end{array}$ & 5.21 & 121 & 12.10 \\
\hline 95 & 1998 & $\begin{array}{l}\text { Bruderl, J. and } \\
\text { Preisendorfer, P. }\end{array}$ & $\begin{array}{l}\text { Network Support and the } \\
\text { Success of Newly Founded } \\
\text { Businesses. }\end{array}$ & Journal & $\begin{array}{l}\text { Small } \\
\text { Business } \\
\text { Economics } \\
\end{array}$ & 5.21 & 66 & 6.60 \\
\hline 96 & 1998 & Hellmann, T. & $\begin{array}{l}\text { The Allocation of Control } \\
\text { Rights in Venture Capital } \\
\text { Contracts. }\end{array}$ & Journal & $\begin{array}{l}\text { RAND } \\
\text { Journal of } \\
\text { Economics }\end{array}$ & 5.21 & 64 & 6.40 \\
\hline 97 & 1997 & $\begin{array}{l}\text { Reynolds, P. and } \\
\text { White, S.B. }\end{array}$ & $\begin{array}{l}\text { The Entrepreneurial Process: } \\
\text { Economic Growth, Men, } \\
\text { Women and Minorities, } \\
\text { Westport, CN: Quorum. }\end{array}$ & Book & & 5.21 & 54 & 4.91 \\
\hline 98 & 1997 & $\begin{array}{l}\text { Teece, D., } \\
\text { Pisano, G. and } \\
\text { Sheen, A. }\end{array}$ & $\begin{array}{l}\text { Dynamic capabilities and } \\
\text { strategic management. }\end{array}$ & Journal & $\begin{array}{l}\text { Strategic } \\
\text { Management } \\
\text { Journal }\end{array}$ & 5.21 & 1384 & 125.82 \\
\hline 99 & 1991 & Krugman, P. & $\begin{array}{l}\text { Geography and Trade, } \\
\text { Cambridge, MA: MIT Press. }\end{array}$ & Book & & 5.13 & 1216 & 71.53 \\
\hline 100 & 1990 & Bates, T. & $\begin{array}{l}\text { Entrepreneur Human Capital } \\
\text { Inputs and Small Business } \\
\text { Longevity. }\end{array}$ & Journal & $\begin{array}{l}\text { Review of } \\
\text { Economics } \\
\text { and Statistics }\end{array}$ & 5.13 & 157 & 8.72 \\
\hline 101 & 1990 & $\begin{array}{l}\text { Eisenhardt, K. } \\
\text { and Schoonhoven, } \\
\text { C.B. }\end{array}$ & $\begin{array}{l}\text { Organizational growth: } \\
\text { linking founding team, } \\
\text { strategy, environment and } \\
\text { growth among US } \\
\text { semiconductor ventures, } \\
\text { 1978- 1988. }\end{array}$ & Journal & $\begin{array}{l}\text { Administrative } \\
\text { Science } \\
\text { Quarterly }\end{array}$ & 5.13 & 314 & 17.44 \\
\hline
\end{tabular}




\begin{tabular}{|c|c|c|c|c|c|c|c|c|}
\hline 102 & 1990 & $\begin{array}{l}\text { Evans, D. and } \\
\text { Leighton, L. }\end{array}$ & $\begin{array}{l}\text { Small business formation by } \\
\text { unemployed and employed } \\
\text { workers. }\end{array}$ & Journal & $\begin{array}{l}\text { Small } \\
\text { Business } \\
\text { Economics }\end{array}$ & 5.13 & 47 & 2.61 \\
\hline 103 & 1990 & Sahlman, W. & $\begin{array}{l}\text { The Structure and } \\
\text { Governance of Venture- } \\
\text { capital Organizations. }\end{array}$ & Journal & $\begin{array}{l}\text { Journal of } \\
\text { Financial } \\
\text { Economics }\end{array}$ & 5.13 & 270 & 15.00 \\
\hline 104 & 1988 & $\begin{array}{l}\text { Acs, Z.J. and } \\
\text { Audretsch, D. }\end{array}$ & $\begin{array}{l}\text { Innovation in Large and } \\
\text { Small Firms-an Empirical- } \\
\text { Analysis. }\end{array}$ & Journal & $\begin{array}{l}\text { American } \\
\text { Economic } \\
\text { Review }\end{array}$ & 5.13 & 247 & 12.35 \\
\hline 105 & 1986 & $\begin{array}{l}\text { Roure, J.B. and } \\
\text { Maidique, M A. }\end{array}$ & $\begin{array}{l}\text { Linking prefunding factors } \\
\text { and high-technology venture } \\
\text { success. }\end{array}$ & Journal & $\begin{array}{l}\text { Journal of } \\
\text { Business } \\
\text { Venturing }\end{array}$ & 5.13 & 61 & 2.77 \\
\hline 106 & 1986 & $\begin{array}{l}\text { Sexton, D. and } \\
\text { Smilor, R. }\end{array}$ & $\begin{array}{l}\text { The art and science of } \\
\text { entrepreneurship, } \\
\text { Cambridge, MA : Ballinger. }\end{array}$ & Book & & 5.13 & 12 & 0.55 \\
\hline 107 & 1995 & $\begin{array}{l}\text { Gatewood, E., } \\
\text { Shaver, K. and } \\
\text { Gartner, W. }\end{array}$ & $\begin{array}{l}\text { A longitudinal study of } \\
\text { cognitive factors influencing } \\
\text { start-up behaviors and } \\
\text { success at venture creation. }\end{array}$ & Journal & $\begin{array}{l}\text { Journal of } \\
\text { Business } \\
\text { Venturing }\end{array}$ & 4.96 & 45 & 3.46 \\
\hline 108 & 1995 & $\begin{array}{l}\text { McGee, J., } \\
\text { Dowling, M. and } \\
\text { Megginson, W. }\end{array}$ & $\begin{array}{l}\text { Cooperative Strategy and } \\
\text { New Venture Performance: } \\
\text { The Role of Business } \\
\text { Strategy and Management. }\end{array}$ & Journal & $\begin{array}{l}\text { Strategic } \\
\text { Management } \\
\text { Journal }\end{array}$ & 4.96 & 36 & 2.77 \\
\hline 109 & 1995 & $\begin{array}{l}\text { Palich, L. and } \\
\text { Bagby, R. }\end{array}$ & $\begin{array}{l}\text { Using cognitive theory to } \\
\text { explain entrepreneurial risk- } \\
\text { taking: Challenging } \\
\text { conventional wisdom. }\end{array}$ & Journal & $\begin{array}{l}\text { Journal of } \\
\text { Business } \\
\text { Venturing }\end{array}$ & 4.96 & 61 & 4.69 \\
\hline 110 & 1980 & Brockhaus, R. & $\begin{array}{l}\text { Risk taking propensity of } \\
\text { entrepreneurs. }\end{array}$ & Journal & $\begin{array}{l}\text { Academy of } \\
\text { Management } \\
\text { Journal }\end{array}$ & 4.86 & 146 & 5.21 \\
\hline 111 & 1979 & Aldrich, H. & $\begin{array}{l}\text { Organizations and } \\
\text { Environments, Englewood } \\
\text { Cliffs, NJ: Prentice-Hall. }\end{array}$ & Book & & 4.86 & 1323 & 45.62 \\
\hline 112 & 1979 & $\begin{array}{l}\text { Kihlstrom, R.E. } \\
\text { and Laffont, J.J. }\end{array}$ & $\begin{array}{l}\text { A General Equilibrium } \\
\text { Entrepreneurial Theory of } \\
\text { Firm Formation Based on } \\
\text { Risk Aversion. }\end{array}$ & Journal & $\begin{array}{l}\text { Journal of } \\
\text { Political } \\
\text { Economy }\end{array}$ & 4.86 & 195 & 6.72 \\
\hline 113 & 1962 & Arrow, K. & $\begin{array}{l}\text { Economic welfare and the } \\
\text { allocation of resources for } \\
\text { inventions, in R. Nelson } \\
\text { (ed),The Rate and Direction } \\
\text { of Inventive Activity, } \\
\text { Princeton, NJ, Princeton } \\
\text { University Press. }\end{array}$ & $\begin{array}{l}\text { Book } \\
\text { chapter }\end{array}$ & & 4.86 & 1158 & 25.17 \\
\hline 114 & 1985 & $\begin{array}{l}\text { MacMillan, I.C., } \\
\text { Siegel, R.M. and } \\
\text { Subba Narasimha, } \\
\text { P.N. }\end{array}$ & $\begin{array}{l}\text { Criteria used by venture } \\
\text { capitalists to evaluate new } \\
\text { ventures. }\end{array}$ & Journal & $\begin{array}{l}\text { Journal of } \\
\text { Business } \\
\text { Venturing } \\
\end{array}$ & 4.79 & 125 & 5.43 \\
\hline 115 & 1983 & Kanter, R.M. & $\begin{array}{l}\text { The change masters, New } \\
\text { York: Simon and Schuster. }\end{array}$ & Book & & 4.79 & 1222 & 48.88 \\
\hline 116 & 1994 & $\begin{array}{l}\text { Fried V.H. and } \\
\text { Hisrich R.D. }\end{array}$ & $\begin{array}{l}\text { Toward A Model Of } \\
\text { Venture Capital Investment } \\
\text { Decision Making. }\end{array}$ & Journal & $\begin{array}{l}\text { Financial } \\
\text { Management }\end{array}$ & 4.65 & 40 & 2.86 \\
\hline
\end{tabular}




\begin{tabular}{|c|c|c|c|c|c|c|c|c|}
\hline 117 & 1993 & $\begin{array}{l}\text { Aldrich, H. and } \\
\text { Wiedenmayer, G. }\end{array}$ & $\begin{array}{l}\text { From traits to rates: An } \\
\text { ecological perspective on } \\
\text { organizational foundings, in } \\
\text { J. Katz and R. Brockhaus } \\
\text { (eds), Advances in } \\
\text { Entrepreneurship, Firm } \\
\text { Emergenceand Growth, } \\
\text { Greenwich, CT: JAI Press. }\end{array}$ & $\begin{array}{l}\text { Book } \\
\text { chapter }\end{array}$ & & 4.65 & 47 & 3.13 \\
\hline 118 & 1993 & $\begin{array}{l}\text { Jaffe, A., } \\
\text { Trajtenberg, M. } \\
\text { and Henderson, } \\
\text { R. }\end{array}$ & $\begin{array}{l}\text { Geographic Localization of } \\
\text { Knowledge Spillovers as } \\
\text { Evidenced by Patent } \\
\text { Citations. }\end{array}$ & Journal & $\begin{array}{l}\text { Quarterly } \\
\text { Journal of } \\
\text { Economics }\end{array}$ & 4.65 & 754 & 50.27 \\
\hline 119 & 1991 & $\begin{array}{l}\text { Covin, J. and } \\
\text { Slevin, D. }\end{array}$ & $\begin{array}{l}\text { A conceptual model of } \\
\text { entrepreneurship as firm } \\
\text { behavior. }\end{array}$ & Journal & $\begin{array}{l}\text { Entrepreneur- } \\
\text { ship Theory } \\
\text { and Practice }\end{array}$ & 4.49 & 132 & 7.76 \\
\hline 120 & 1990 & Aldrich, $\mathrm{H}$. & $\begin{array}{l}\text { Using an ecological } \\
\text { perspective to study } \\
\text { organizational founding } \\
\text { rates. }\end{array}$ & Journal & $\begin{array}{l}\text { Entrepreneur- } \\
\text { ship Theory } \\
\text { and Practice }\end{array}$ & 4.49 & 34 & 1.89 \\
\hline 121 & 1990 & $\begin{array}{l}\text { Amit, R., } \\
\text { Glosten, L. and } \\
\text { Mueller, E. }\end{array}$ & $\begin{array}{l}\text { Entrepreneurial ability, } \\
\text { venture investments and risk } \\
\text { sharing. }\end{array}$ & Journal & $\begin{array}{l}\text { Management } \\
\text { Science }\end{array}$ & 4.49 & 50 & 2.78 \\
\hline 122 & 1990 & $\begin{array}{l}\text { Freear, J. and } \\
\text { Wetzel, W. }\end{array}$ & $\begin{array}{l}\text { Who bankrolls high-tech } \\
\text { entrepreneurs?. }\end{array}$ & Journal & $\begin{array}{l}\text { Journal of } \\
\text { Business } \\
\text { Venturing }\end{array}$ & 4.49 & 22 & 1.22 \\
\hline 123 & 1990 & Porter, M. & $\begin{array}{l}\text { The competitive advantage } \\
\text { of nations, New York: Free } \\
\text { Press. }\end{array}$ & Book & & 4.49 & 3130 & 173.89 \\
\hline 124 & 1987 & $\begin{array}{l}\text { Sandberg, W.R. } \\
\text { and Hofer, C.W. }\end{array}$ & $\begin{array}{l}\text { Improving new venture } \\
\text { performance: The role of } \\
\text { strategy, industry structure } \\
\text { and the entrepreneur. }\end{array}$ & Journal & $\begin{array}{l}\text { Journal of } \\
\text { Business } \\
\text { Venturing }\end{array}$ & 4.49 & 116 & 5.52 \\
\hline 125 & 1987 & Wetzel, W. & $\begin{array}{l}\text { The informal venture capital } \\
\text { market: Aspects of scale and } \\
\text { market efficiency. }\end{array}$ & Journal & $\begin{array}{l}\text { Journal of } \\
\text { Business } \\
\text { Venturing }\end{array}$ & 4.49 & 16 & 0.76 \\
\hline 126 & 1992 & $\begin{array}{l}\text { Gartner, W., } \\
\text { Bird, B. and } \\
\text { Starr, J. }\end{array}$ & $\begin{array}{l}\text { Acting as if: Differentiating } \\
\text { entrepreneurial from } \\
\text { organizational behavior. }\end{array}$ & Journal & $\begin{array}{l}\text { Entrepreneur- } \\
\text { ship Theory } \\
\text { and Practice }\end{array}$ & 4.48 & 56 & 3.50 \\
\hline 127 & 1992 & $\begin{array}{l}\text { Glaeser, E., } \\
\text { Kallal, H., } \\
\text { Scheinkman, J. } \\
\text { and Shleifer, A. }\end{array}$ & Growth in cities. & Journal & $\begin{array}{l}\text { Journal of } \\
\text { Political } \\
\text { Economy }\end{array}$ & 4.48 & 480 & 30.00 \\
\hline 128 & 1992 & $\begin{array}{l}\text { Sexton, D. and } \\
\text { Kasarda, J. }\end{array}$ & $\begin{array}{l}\text { The State of the Art of } \\
\text { Entrepreneurship, Boston, } \\
\text { MA: PWS Kent. }\end{array}$ & Book & & 4.48 & 7 & 0.44 \\
\hline 129 & 1978 & Lucas, R. E. & $\begin{array}{l}\text { On the Size Distribution of } \\
\text { Business Firms. }\end{array}$ & Journal & $\begin{array}{l}\text { Bell Journal of } \\
\text { Economics }\end{array}$ & 4.32 & 310 & 10.33 \\
\hline 130 & 1975 & Williamson, O. & $\begin{array}{l}\text { Markets and hierarchies: } \\
\text { Analysis and antitrust } \\
\text { implications, New York: } \\
\text { Free Press. }\end{array}$ & Book & & 4.32 & 5577 & 169,00 \\
\hline 131 & 1930 & Weber, M. & $\begin{array}{l}\text { The protestant ethic and the } \\
\text { spirit of capitalism, New } \\
\text { York: Scribners. }\end{array}$ & Book & & 4.32 & 4593 & 88.33 \\
\hline
\end{tabular}




\begin{tabular}{|c|c|c|c|c|c|c|c|c|}
\hline 132 & 1984 & $\begin{array}{l}\text { Hambrick, D. and } \\
\text { Mason, P. }\end{array}$ & $\begin{array}{l}\text { Upper echelons: The } \\
\text { organization as a reflection } \\
\text { of its top managers. }\end{array}$ & Journal & $\begin{array}{l}\text { Academy of } \\
\text { Management } \\
\text { Review }\end{array}$ & 4.19 & 944 & 39.33 \\
\hline 133 & 1983 & $\begin{array}{l}\text { Churchill, N.C. } \\
\text { and Lewis, V. }\end{array}$ & $\begin{array}{l}\text { The Five Stages of Small } \\
\text { Business Growth. }\end{array}$ & Journal & $\begin{array}{l}\text { Harvard } \\
\text { Business } \\
\text { Review } \\
\end{array}$ & 4.19 & 164 & 6.56 \\
\hline 134 & 1982 & $\begin{array}{l}\text { Bruno, A. and } \\
\text { Tyebjee, T. }\end{array}$ & $\begin{array}{l}\text { The environment for } \\
\text { entrepreneurship, in C. Kent, } \\
\text { D. Sexton and K. Vesper } \\
\text { (eds), Encyclopedia of } \\
\text { Entrepreneurship, } \\
\text { Englewood Cliffs, NJ: } \\
\text { Prentice-Hall. }\end{array}$ & $\begin{array}{l}\text { Book } \\
\text { chapter }\end{array}$ & & 4.19 & 35 & 1.35 \\
\hline 135 & 1982 & $\begin{array}{l}\text { Shapero, A. and } \\
\text { Sokol, L. }\end{array}$ & $\begin{array}{l}\text { The social dimensions of } \\
\text { entrepreneurship, in C. Kent } \\
\text { et al. (eds), Encyclopedia of } \\
\text { Entrepreneurship. } \\
\text { Englewood Cliffs, NJ: } \\
\text { Prentice Hall. }\end{array}$ & $\begin{array}{l}\text { Book } \\
\text { chapter }\end{array}$ & & 4.19 & 117 & 4.50 \\
\hline
\end{tabular}




\begin{tabular}{|c|c|c|c|c|c|c|c|c|c|c|c|c|c|c|}
\hline \multicolumn{15}{|c|}{ Appendix 2} \\
\hline & $\begin{array}{l}\text { William } \\
\text { Gartner }\end{array}$ & $\begin{array}{l}\text { Howard } \\
\text { Aldrich }\end{array}$ & $\begin{array}{l}\text { Israel } \\
\text { Kirzner }\end{array}$ & $\begin{array}{l}\text { Scott } \\
\text { Shane }\end{array}$ & $\begin{array}{l}\text { Sankaran } \\
\text { Venkataraman }\end{array}$ & $\begin{array}{l}\text { William } \\
\text { Baumol }\end{array}$ & $\begin{array}{l}\text { David } \\
\text { Audretsch }\end{array}$ & $\begin{array}{l}\text { David } \\
\text { Birch }\end{array}$ & $\begin{array}{l}\text { Amar } \\
\text { Bhidé }\end{array}$ & $\begin{array}{l}\text { David } \\
\text { Blanch- } \\
\text { flower }\end{array}$ & $\begin{array}{l}\text { David } \\
\text { Storey }\end{array}$ & $\begin{array}{l}\text { Mark } \\
\text { Casson }\end{array}$ & $\begin{array}{l}\text { Josh } \\
\text { Lerner }\end{array}$ & $\begin{array}{l}\text { David } \\
\text { Evans }\end{array}$ \\
\hline Year of birth & 1953 & 1943 & 1930 & 1964 & 1956 & 1922 & 1954 & 1937 & 1955 & 1952 & 1947 & 1945 & 1960 & 1954 \\
\hline \multicolumn{15}{|c|}{ Career trajectory } \\
\hline $\mathrm{PhD}$ & 1982 & 1969 & 1957 & 1992 & 1989 & 1949 & 1980 & 1966 & 1988 & 1985 & 1978 & 1969 & 1992 & 1983 \\
\hline $\begin{array}{l}\text { Assistant } \\
\text { professor }\end{array}$ & 1981 & 1969 & 1957 & 1993 & 1989 & - & 1980 & 1966 & 1988 & 1986 & - & 1969 & 1991 & - \\
\hline $\begin{array}{l}\text { Associate } \\
\text { professor }\end{array}$ & - & 1974 & 1961 & 1999 & 1995 & - & - & 1970 & 1993 & 1989 & - & 1977 & 1996 & 1983 \\
\hline Full professor & 1994 & 1979 & 1968 & 2001 & 2001 & 1949 & 1996 & - & 2000 & 1993 & 1990 & 1981 & 1999 & 1985 \\
\hline $\begin{array}{l}\text { First core } \\
\text { work }\end{array}$ & 1985 & 1979 & 1973 & 2000 & 1997 & 1968 & 1988 & 1979 & 2000 & 1998 & 1994 & 1982 & 1999 & 1989 \\
\hline \multicolumn{15}{|l|}{ Mobility } \\
\hline $\begin{array}{l}\text { No academic } \\
\text { employments }\end{array}$ & 5 & 3 & 1 & 6 & 3 & 2 & 6 & 2 & 4 & 7 & 3 & 1 & 1 & 2 \\
\hline $\begin{array}{l}\text { Visiting } \\
\text { professorships }\end{array}$ & 1 & 9 & na & 3 & 0 & na & 7 & 0 & 1 & 0 & 4 & 3 & na & 1 \\
\hline $\begin{array}{l}\text { No industry } \\
\text { employments }\end{array}$ & 0 & 0 & na & 0 & 0 & na & 0 & $\begin{array}{c}20 \\
\text { years }\end{array}$ & 0 & $\begin{array}{c}0 \\
\text { Consult. }\end{array}$ & $\begin{array}{c}0 \\
\text { Policy }\end{array}$ & 0 & na & $\begin{array}{c}22 \\
\text { years }\end{array}$ \\
\hline \multicolumn{15}{|c|}{ Scientific productivity } \\
\hline Total publ. & 84 & 163 & na & 99 & 44 & na & 354 & 5 & 34 & 104 & 139 & 143 & 96 & 101 \\
\hline Books & 2 & 8 & na & 11 & 3 & na & 12 & 1 & 7 & 3 & 9 & 19 & 9 & 5 \\
\hline Edited books & 1 & 0 & na & 3 & 1 & na & 27 & 0 & 0 & 1 & 8 & 19 & 2 & 3 \\
\hline Book chapters & 28 & 66 & na & 7 & 11 & na & 118 & 3 & 4 & 24 & 41 & 59 & 18 & 18 \\
\hline $\begin{array}{l}\text { Singel- } \\
\text { authored } \\
\text { articles }\end{array}$ & 18 & 24 & na & 32 & 3 & na & 56 & 1 & 19 & 23 & 26 & 26 & 20 & 24 \\
\hline $\begin{array}{l}\text { Multi- } \\
\text { authored } \\
\text { articles }\end{array}$ & 35 & 65 & na & 46 & 26 & na & 141 & 0 & 4 & 53 & 55 & 20 & 47 & 51 \\
\hline $\begin{array}{l}\text { Co-authorship } \\
\text { ratio }\end{array}$ & 0.51 & 0.37 & na & 0.70 & 0.12 & na & 0.40 & 1.00 & 4.75 & 0.43 & 0.47 & 1.30 & 0.43 & 0.47 \\
\hline
\end{tabular}




\section{CIRCLE ELECTRONIC WORKING PAPERS SERIES (EWP)}

CIRCLE (Centre for Innovation, Research and Competence in the Learning Economy) is a multidisciplinary research centre set off by several faculties at Lund University and Blekinge Institute of Technology. CIRCLE has a mandate to conduct multidisciplinary research and education on the following issues: Long-term perspectives on innovation, structural change and economic growth, Entrepreneurship and venture capital formation with a special focus on new ventures, The dynamics of R\&D systems and technological systems, including their impact on entrepreneurship and growth, Regional innovation systems in different national and international contexts and International comparative analyses of national innovation systems. Special emphasis is done on innovation policies and research policies. 10 nationalities and 14 disciplines are represented among the CIRCLE staff.

The CIRCLE Electronic Working Paper Series are intended to be an instrument for early dissemination of the research undertaken by CIRCLE researchers, associates and visiting scholars and stimulate discussion and critical comment.

The working papers present research results that in whole or in part are suitable for submission to a refereed journal or to the editor of a book or have already been submitted and/or accepted for publication.

CIRCLE EWPs are available on-line at: http://www.circle.lu.se/publications

Available papers:

2011

WP 2011/01

SMEs' absorptive capacities and large firms' knowledge spillovers: Micro evidence from Mexico

Claudia de Fuentes and Gabriela Dutrénit

WP 2011/02

Comparing knowledge bases: on the organisation and geography of knowledge flows in the regional innovation system of Scania, southern Sweden Roman Martin and Jerker Moodysson

WP 2011/03

Organizational paths of commercializing patented inventions: The effects of transaction costs, firm capabilities, and collaborative ties

Taehyun Jung and John P. Walsh

WP 2011/04

Global Innovation Networks: what are they and where can we find them? (Conceptual and Empirical issues)

Helena Barnard and Cristina Chaminade

WP 2011/05

Swedish Business R\&D and its Export Dependence

Karin Bergman and Olof Ejermo 
WP 2011/06

Innovation Policy Design: Identification of Systemic Problems Charles Edquist

WP 2011/07

Regional Institutional Environment and Its Impact on Intra-firm and Interorganisational Innovation Networks: A Comparative Case Study in China and Switzerland

Ju LIU

WP 2011/08

Entrepreneurship: Exploring the Knowledge Base

Hans Landström, Gouya Harirchi and Fredrik Åström 
WP 2010/01

Innovation policies for development: towards a systemic experimentation based approach

Cristina Chaminade, Bengt-Ake Lundvall, Jan Vang-Lauridsen and KJ Joseph

WP 2010/02

From Basic Research to Innovation: Entrepreneurial Intermediaries for Research Commercialization at Swedish 'Strong Research Environments'

Fumi Kitagawa and Caroline Wigren

WP 2010/03 Different competences, different modes in the globalization of innovation?

A comparative study of the Pune and Beijing regions

Monica Plechero and Cristina Chaminade

WP 2010/04 Technological Capability Building in Informal Firms in the Agricultural

Subsistence Sector In Tanzania: Assessing the Role of Gatsby Clubs

Astrid Szogs and Kelefa Mwantima

WP 2010/05

The Swedish Paradox - Unexploited Opportunities!

Charles Edquist

WP 2010/06

A three-stage model of the Academy-Industry linking process: the perspective of both agents

Claudia De Fuentes and Gabriela Dutrénit

WP 2010/07

Innovation in symbolic industries: the geography and organisation of knowledge sourcing

Roman Martin and Jerker Moodysson

WP 2010/08

Towards a spatial perspective on sustainability transitions

Lars Coenen, Paul Benneworth and Bernhard Truffer

WP 2010/09

The Swedish national innovation system and its relevance for the emergence of global innovation networks

Cristina Chaminade, Jon Mikel Zabala and Adele Treccani

WP 2010/10

Who leads Research Productivity Change? Guidelines for R\&D policy makers Fernando Jiménez-Sáez, Jon Mikel Zabala and José L- Zofío

WP 2010/11

Research councils facing new science and technology

Frank van der Most and Barend van der Meulen 
WP 2010/12

From new to the firm to new to the world. Effect of geographical proximity and technological capabilities on the degree of novelty in emerging economies Monica Plechero and Cristina Chaminade

WP 2010/13

Are knowledge-bases enough? A comparative study of the geography of knowledge sources in China (Great Beijing) and India (Pune)

Cristina Chaminade

WP 2010/14

Regional Innovation Policy beyond 'Best Practice': Lessons from Sweden Roman Martin, Jerker Moodysson and Elena Zukauskaite

WP 2010/15

Innovation in cultural industries: The role of university links

Elena Zukauskaite

WP 2010/16

Use and non-use of research evaluation. A literature review

Frank van der Most

WP 2010/17

Upscaling emerging niche technologies in sustainable energy: an international comparison of policy approaches

Lars Coenen, Roald Suurs and Emma van Sandick

2009

WP 2009/01

Building systems of innovation in less developed countries: The role of intermediate organizations.

Szogs, Astrid; Cummings, Andrew and Chaminade, Cristina

WP 2009/02

The Widening and Deepening of Innovation Policy: What Conditions Provide for Effective Governance?

Borrás, Susana

WP 2009/03

Managerial learning and development in small firms: implications based on observations of managerial work

Gabrielsson, Jonas and Tell, Joakim

WP 2009/04

University professors and research commercialization: An empirical test of the "knowledge corridor" thesis

Gabrielsson, Jonas, Politis, Diamanto and Tell, Joakim

WP 2009/05

On the concept of global innovation networks

Chaminade, Cristina

WP 2009/06 
Technological Waves and Economic Growth - Sweden in an International Perspective 1850-2005

Schön, Lennart

WP 2009/07

Public Procurement of Innovation Diffusion: Exploring the Role of Institutions and Institutional Coordination

Rolfstam, Max; Phillips, Wendy and Bakker, Elmer

WP 2009/08

Local niche experimentation in energy transitions: a theoretical and empirical exploration of proximity advantages and disadvantages

Lars Coenen, Rob Raven, Geert Verbong

WP 2009/9

Product Development Decisions: An empirical approach to Krishnan and Ulrich Jon Mikel Zabala, Tina Hannemann

WP 2009/10

Dynamics of a Technological Innovator Network and its impact on technological performance

Ju Liu, Cristina Chaminade

WP 2009/11

The Role of Local Universities in Improving Traditional SMEs Innovative Performances: The Veneto Region Case

Monica Plechero

WP 2009/12

Comparing systems approaches to innovation and technological change for sustainable and competitive economies: an explorative study into conceptual commonalities, differences and complementarities

Coenen, Lars and Díaz López, Fernando J.

WP 2009/13

Public Procurement for Innovation (PPI) - a Pilot Study

Charles Edquist

WP 2009/14

Outputs of innovation systems: a European perspective

Charles Edquist and Jon Mikel Zabala

2008

WP 2008/01

R\&D and financial systems: the determinants of R\&D expenditures in the Swedish pharmaceutical industry

Malmberg, Claes

WP 2008/02

The Development of a New Swedish Innovation Policy. A Historical Institutional Approach

Persson, Bo 
WP 2008/03

The Effects of R\&D on Regional Invention and Innovation

Olof Ejermo and Urban Gråsjö

WP 2008/04

Clusters in Time and Space: Understanding the Growth and Transformation of Life Science in Scania

Moodysson, Jerker; Nilsson, Magnus; Svensson Henning, Martin

WP 2008/05

Building absorptive capacity in less developed countries

The case of Tanzania

Szogs, Astrid; Chaminade, Cristina and Azatyan, Ruzana

WP 2008/06

Design of Innovation Policy through Diagnostic Analysis:

Identification of Systemic Problems (or Failures)

Edquist, Charles

WP 2008/07

The Swedish Paradox arises in Fast-Growing Sectors

Ejermo, Olof; Kander, Astrid and Svensson Henning, Martin

WP 2008/08

Policy Reforms, New University-Industry Links and Implications for Regional Development in Japan

Kitagawa, Fumi

WP 2008/09

The Challenges of Globalisation: Strategic Choices for Innovation Policy

Borrás, Susana; Chaminade, Cristina and Edquist, Charles

WP 2008/10

Comparing national systems of innovation in Asia and Europe: theory and comparative framework

Edquist, Charles and Hommen, Leif

WP 2008/11

Putting Constructed Regional Advantage into Swedish Practice? The case of the VINNVÄXT initiative 'Food Innovation at Interfaces'

Coenen, Lars; Moodysson, Jerker

WP 2008/12

Energy transitions in Europe: 1600-2000

Kander, Astrid; Malanima, Paolo and Warde, Paul

WP 2008/13

RIS and Developing Countries: Linking firm technological capabilities to regional systems of innovation

Padilla, Ramon; Vang, Jan and Chaminade, Cristina 
WP 2008/14

The paradox of high R\&D input and low innovation output: Sweden

Bitarre, Pierre; Edquist, Charles; Hommen, Leif and Ricke, Annika

WP 2008/15

Two Sides of the Same Coin? Local and Global Knowledge Flows in Medicon Valley

Moodysson, Jerker; Coenen, Lars and Asheim, Bjørn

WP 2008/16

Electrification and energy productivity

Enflo, Kerstin; Kander, Astrid and Schön, Lennart

WP 2008/17

Concluding Chapter: Globalisation and Innovation Policy

Hommen, Leif and Edquist, Charles

WP 2008/18

Regional innovation systems and the global location of innovation activities: Lessons from China

Yun-Chung, Chen; Vang, Jan and Chaminade, Cristina

WP 2008/19

The Role of mediator organisations in the making of innovation systems in least developed countries. Evidence from Tanzania

Szogs, Astrid

WP 2008/20

Globalisation of Knowledge Production and Regional Innovation Policy:

Supporting Specialized Hubs in the Bangalore Software Industry

Chaminade, Cristina and Vang, Jan

WP 2008/21

Upgrading in Asian clusters: Rethinking the importance of interactive-learning Chaminade, Cristina and Vang, Jan

2007

WP 2007/01

Path-following or Leapfrogging in Catching-up: the Case of Chinese Telecommunication Equipment Industry

Liu, Xielin

WP 2007/02

The effects of institutional change on innovation and productivity growth in the Swedish pharmaceutical industry

Malmberg, Claes

WP 2007/03

Global-local linkages, Spillovers and Cultural Clusters: Theoretical and Empirical insights from an exploratory study of Toronto's Film Cluster

Vang, Jan; Chaminade, Cristina 
WP 2007/04

Learning from the Bangalore Experience: The Role of Universities in an Emerging Regional Innovation System

Vang, Jan; Chaminade, Cristina.; Coenen, Lars.

WP 2007/05

Industrial dynamics and innovative pressure on energy -Sweden with European and Global outlooks

Schön, Lennart; Kander, Astrid.

WP 2007/06

In defence of electricity as a general purpose technology

Kander, Astrid; Enflo, Kerstin; Schön, Lennart

WP 2007/07

Swedish business research productivity - improvements against international trends

Ejermo, Olof; Kander, Astrid

WP 2007/08

Regional innovation measured by patent data - does quality matter?

Ejermo, Olof

WP 2007/09

Innovation System Policies in Less Successful Developing countries: The case of Thailand

Intarakumnerd, Patarapong; Chaminade, Cristina

2006

WP 2006/01

The Swedish Paradox

Ejermo, Olof; Kander, Astrid

WP 2006/02

Building RIS in Developing Countries: Policy Lessons from Bangalore, India

Vang, Jan; Chaminade, Cristina

WP 2006/03

Innovation Policy for Asian SMEs: Exploring cluster differences

Chaminade, Cristina; Vang, Jan.

WP 2006/04

Rationales for public intervention from a system of innovation approach: the case of VINNOVA.

Chaminade, Cristina; Edquist, Charles

WP 2006/05

Technology and Trade: an analysis of technology specialization and export flows

Andersson, Martin; Ejermo, Olof 
WP 2006/06

A Knowledge-based Categorization of Research-based Spin-off Creation

Gabrielsson, Jonas; Landström, Hans; Brunsnes, E. Thomas

WP 2006/07

Board control and corporate innovation: an empirical study of small technology-based firms

Gabrielsson, Jonas; Politis, Diamanto

WP 2006/08

On and Off the Beaten Path:

Transferring Knowledge through Formal and Informal Networks

Rick Aalbers; Otto Koppius; Wilfred Dolfsma

WP 2006/09

Trends in R\&D, innovation and productivity in Sweden 1985-2002

Ejermo, Olof; Kander, Astrid

WP 2006/10

Development Blocks and the Second Industrial Revolution, Sweden 1900-1974

Enflo, Kerstin; Kander, Astrid; Schön, Lennart

WP 2006/11

The uneven and selective nature of cluster knowledge networks: evidence from the wine industry

Giuliani, Elisa

WP 2006/12

Informal investors and value added: The contribution of investors' experientially acquired resources in the entrepreneurial process

Politis, Diamanto; Gabrielsson, Jonas

WP 2006/13

Informal investors and value added: What do we know and where do we go?

Politis, Diamanto; Gabrielsson, Jonas

WP 2006/14

Inventive and innovative activity over time and geographical space: the case of Sweden

Ejermo, Olof

2005

WP 2005/1

Constructing Regional Advantage at the Northern Edge

Coenen, Lars; Asheim, Bjørn

WP 2005/02

From Theory to Practice: The Use of the Systems of Innovation Approach for Innovation Policy

Chaminade, Cristina; Edquist, Charles

WP 2005/03

The Role of Regional Innovation Systems in a Globalising Economy: Comparing Knowledge Bases and Institutional Frameworks in Nordic Clusters 
Asheim, Bjørn; Coenen, Lars

WP 2005/04

How does Accessibility to Knowledge Sources Affect the Innovativeness of Corporations? Evidence from Sweden

Andersson, Martin; Ejermo, Olof

WP 2005/05

Contextualizing Regional Innovation Systems in a Globalizing Learning Economy: On Knowledge Bases and Institutional Frameworks

Asheim, Bjørn; Coenen, Lars

WP 2005/06

Innovation Policies for Asian SMEs: An Innovation Systems Perspective

Chaminade, Cristina; Vang, Jan

WP 2005/07

Re-norming the Science-Society Relation

Jacob, Merle

WP 2005/08

Corporate innovation and competitive environment

Huse, Morten; Neubaum, Donald O.; Gabrielsson, Jonas

WP 2005/09

Knowledge and accountability: Outside directors' contribution in the corporate value chain

Huse, Morten, Gabrielsson, Jonas; Minichilli, Alessandro

WP 2005/10

Rethinking the Spatial Organization of Creative Industries

Vang, Jan

WP 2005/11

Interregional Inventor Networks as Studied by Patent Co-inventorships

Ejermo, Olof; Karlsson, Charlie

WP 2005/12

Knowledge Bases and Spatial Patterns of Collaboration: Comparing the Pharma and Agro-Food Bioregions Scania and Saskatoon

Coenen, Lars; Moodysson, Jerker; Ryan, Camille; Asheim, Bjørn; Phillips, Peter

WP 2005/13

Regional Innovation System Policy: a Knowledge-based Approach

Asheim, Bjørn; Coenen, Lars; Moodysson, Jerker; Vang, Jan

WP 2005/14

Face-to-Face, Buzz and Knowledge Bases: Socio-spatial implications for learning and innovation policy

Asheim, Bjørn; Coenen, Lars, Vang, Jan

WP 2005/15

The Creative Class and Regional Growth: Towards a Knowledge Based Approach

Kalsø Hansen, Høgni; Vang, Jan; Bjørn T. Asheim 
WP 2005/16

Emergence and Growth of Mjärdevi Science Park in Linköping, Sweden

Hommen, Leif; Doloreux, David; Larsson, Emma

WP 2005/17

Trademark Statistics as Innovation Indicators? - A Micro Study

Malmberg, Claes 